\title{
Olivier Messiaen's Personal Expression of Faith in His Major Solo and Chamber Works with Piano from 1940 to 1944
}

Marie Arlou C. Borillo

West Virginia University

Follow this and additional works at: https://researchrepository.wvu.edu/etd

\section{Recommended Citation}

Borillo, Marie Arlou C., "Olivier Messiaen's Personal Expression of Faith in His Major Solo and Chamber Works with Piano from 1940 to 1944" (2012). Graduate Theses, Dissertations, and Problem Reports. 4835.

https://researchrepository.wvu.edu/etd/4835

This Dissertation is protected by copyright and/or related rights. It has been brought to you by the The Research Repository @ WVU with permission from the rights-holder(s). You are free to use this Dissertation in any way that is permitted by the copyright and related rights legislation that applies to your use. For other uses you must obtain permission from the rights-holder(s) directly, unless additional rights are indicated by a Creative Commons license in the record and/ or on the work itself. This Dissertation has been accepted for inclusion in WVU Graduate Theses, Dissertations, and Problem Reports collection by an authorized administrator of The Research Repository @ WVU.

For more information, please contact researchrepository@mail.wvu.edu. 
Olivier Messiaen's Personal Expression of Faith in His Major Solo and Chamber Works with Piano from 1940 to 1944

Marie Arlou C. Borillo

\author{
Dissertation submitted to the \\ College of Creative Arts \\ at West Virginia University \\ in partial fulfillment of the requirements \\ for the degree of
}

\author{
Doctor of Musical Arts \\ in \\ Piano Performance
}

\author{
Keith Jackson, D.M.A. \\ Lucy Mauro, D.M.A. \\ James Miltenberger, D.M.A., Committee Chair \\ Joy Faini Saab, Ed. D. \\ Christopher Wilkinson, Ph.D., Research Advisor
}

School of Music

Morgantown, West Virginia 2012

Keywords: Olivier Messiaen, Catholic, Religion, Spirituality, Theology,

Vingt Regards sur l'Enfant Jesus, Visions de l'Amen,

Quatuor pour la Fins du Temps,

Piano, Musical Language

Copyright 2012 Marie Arlou C. Borillo 


\title{
ABSTRACT \\ Olivier Messiaen's Personal Expression of Faith in His Major Solo and Chamber Works with Piano from 1940 to 1944
}

\author{
Marie Arlou C. Borillo
}

Throughout the history of Western art music, a number of composers either have been supported financially by religious institutions to create sacred works or have been driven by their own spiritual beliefs to create faith-inspired pieces. With the decrease of Christianity's importance to individuals in Western society throughout time, however, compositions whose genesis arise solely from religious and spiritual inspiration have lessened substantially. This is particularly evident in the music of the Roman Catholic Church from the end of the nineteenth century to the early 1960s, as the Church's liturgical music consisted of a restored Gregorian chant. This eliminated the need for original church compositions, which in turn made composers less inclined to write Catholic religious music during this time.

Although many composers during the twentieth century chose not to write music as a reflection of their faith, one composer, Olivier Messiaen (1908-1992) of France, certainly did not limit his output to secular works. Rather, the majority of Messiaen's oeuvre could be considered a projection of his profound faith, as individual elements within these works belong to larger compositional processes and theories he devised to represent his interpretation of the teachings of the Catholic Church. This paper explores the various beliefs Messiaen held and studies the various compositional techniques the composer used to express his personal theology. Three of the composer's works that featured piano will be studied: Quatuor pour la fin de Temps (194041) for piano, clarinet, violin, and cello; Visions de l'Amen (1943) for two pianos; and Vingt Regards sur l'Enfant Jésus (1944) for solo piano. 


\section{ACKNOWLEDGEMENTS}

There are several people I would like to thank for helping me bring this project to fruition. First and foremost, I would like to thank my research advisor, Dr. Christopher Wilkinson, for his wisdom and guidance throughout this long process. I would like to express my appreciation to Dr. Lucy Mauro, Dr. Keith Jackson, and Dr. Joy Saab for the time they have devoted as members of my committee. Many special thanks to Dr. James Miltenberger for believing in me and not allowing me to throw in the towel. I would also like to extend my gratitude to my all my friends for boosting my morale, particularly Sheila Barnhart for devoting many hours in helping me put this paper together. Finally, I would like to thank my family for their unwavering love and support they have given me in helping me fulfill my dreams. 


\section{CONTENTS}

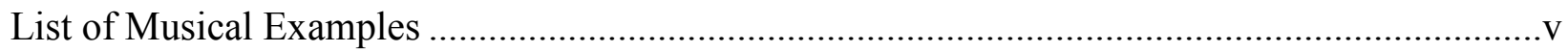

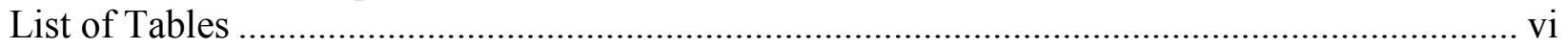

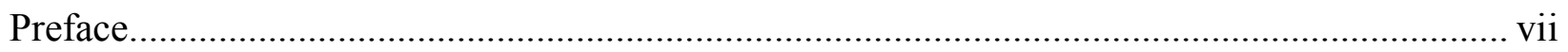

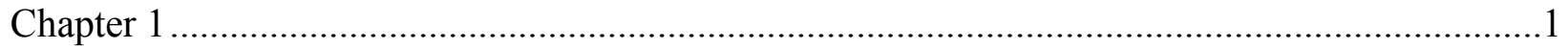

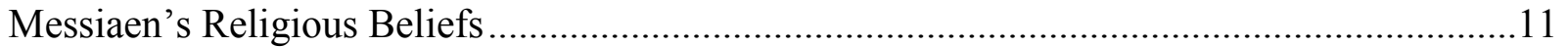

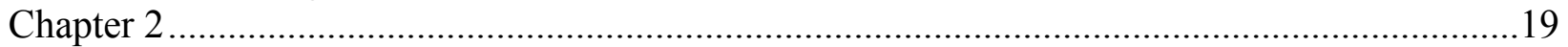

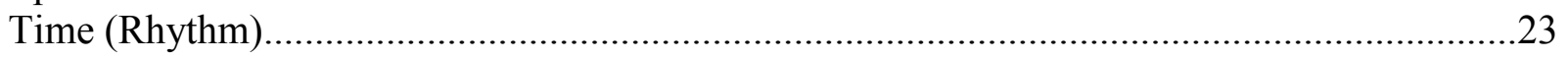

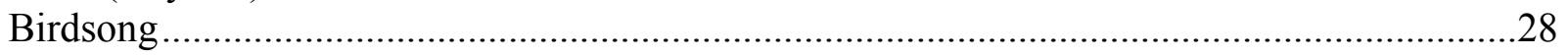

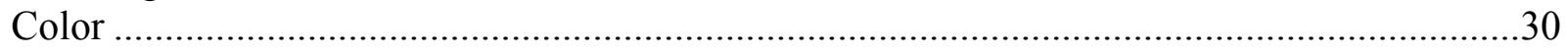

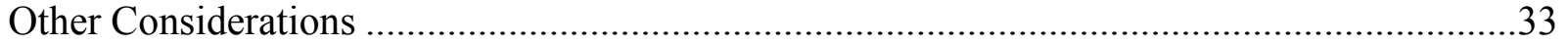

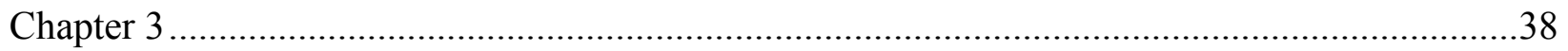

Theme of Creation and the Accompanying Carillons........................................................44

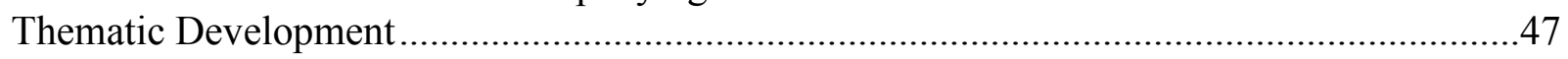

Other Elements and Features: Birdsong and Color...........................................................51

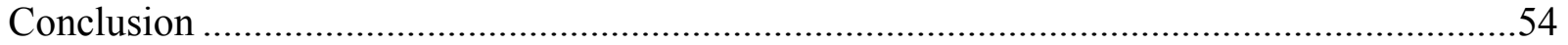

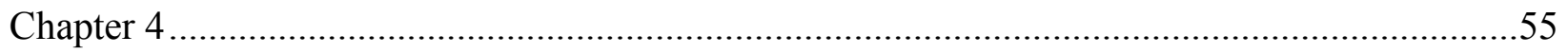

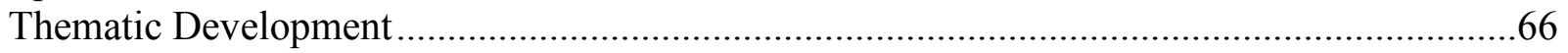

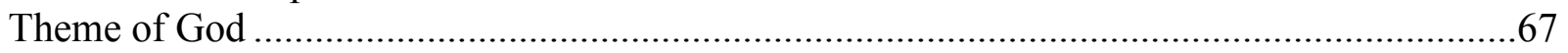

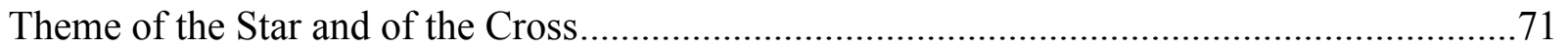

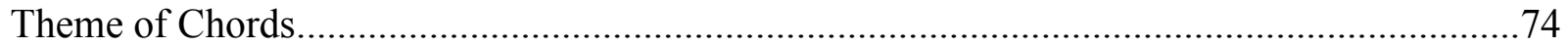

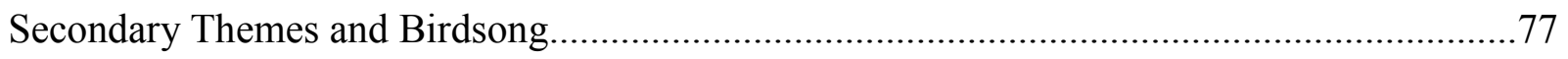

Secondary Themes Derived from the Theme of God ..................................................78

Secondary Themes Derived from the Theme of Chords .............................................. 84

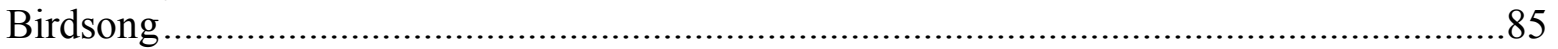

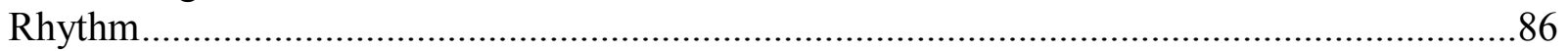

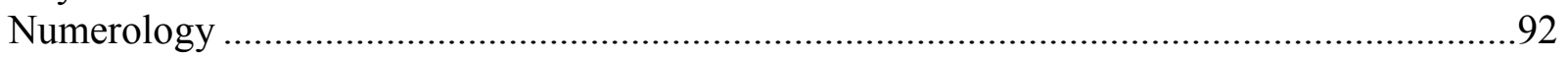

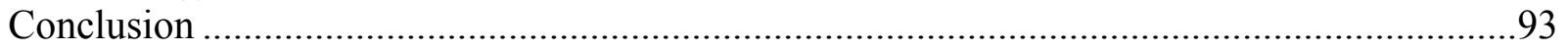

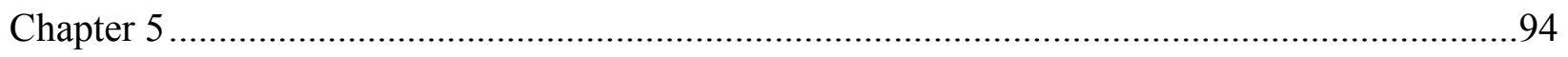

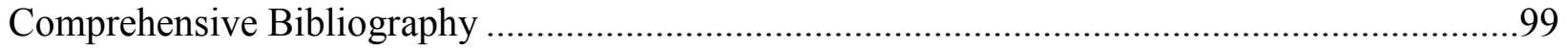




\section{LIST OF MUSICAL EXAMPLES}

Example 2.1: Added Values .........................................................................................25

Example 2.2: "Danse de la fureur, pour les sept trompettes," Principal Theme..........................26

Example 2.3: "Liturgie de cristal," Cello Rhythm ..................................................................27

Example 2.4: "Danse de la fureur, pour les sept trompettes," mm. 29-34.................................28

Example 2.5: Third Mode of the Modes of Limited Transposition

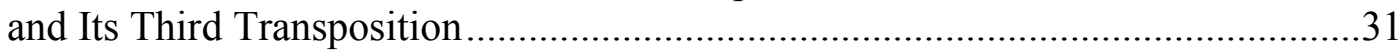

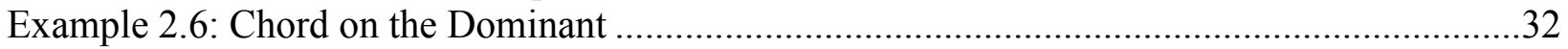

Example 2.7: Chord of Resonance........................................................................................33

Example 2.8a: Combined Compositional Elements in "Fouillis d'arcs-en-ciel, pour l"Ange qui annonce la fin du temps," Cello Theme with Piano Accompaniment ....................34

Example 2.9b: Combined Compositional Elements in "Fouillis d'arcs-en-ciel, pour l'Ange qui annonce la fin du temps", Clarinet Passage with Arpeggiated Chord on the

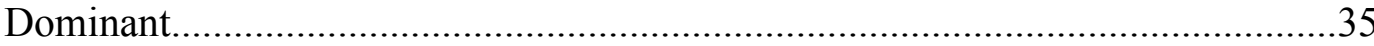

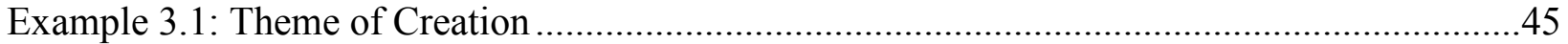

Example 3.2: Carillons I and II from "Amen de la Création" ....................................................47

Example 3.3: Thematic Development of the Theme of Creation

in "Amen de l'agonie de Jésus" ..........................................................................48

Example 3.4: Nonretrogradable Rhythms in "Amen du Desir" ................................................49

Example 3.5: Recurrence of Theme of Creation in "Amen des anges, des saints, du chants des oiseaux" ................................................................50

Example 3.6: Mode Two from the Modes of Limited Transposition ..........................................53

Example 4.1: Theme of God in "Regard du Fils sur le Fils" ...................................................69

Example 4.2: Theme of God in Movement XV, "Le Baiser de l'Énfant Jésus" ..........................70

Example 4.3: Mode Seven from the Modes of Limited Transposition.........................................71

Example 4.4: Theme of the Star and the Cross in Movement II,

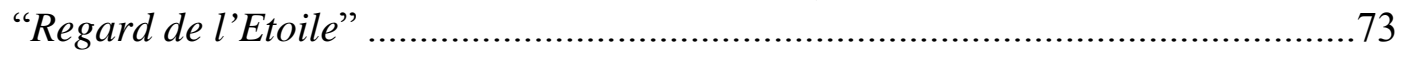

Example 4.5: Theme of Chords as Grouped in Pitch Classes..................................................75

Example 4.6a: Theme of Chords, Movement XIV, "Regards des Anges" ..................................76

Example 4.6b: Theme of Chords, Fragmented, Movement XIV,

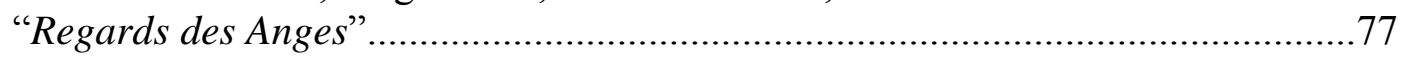

Example 4.7a: Theme of Love in Movement I, "Regard du Pére" ..........................................79

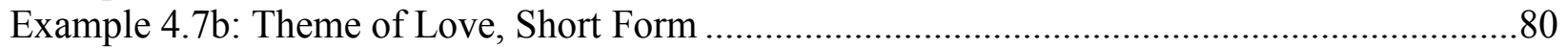

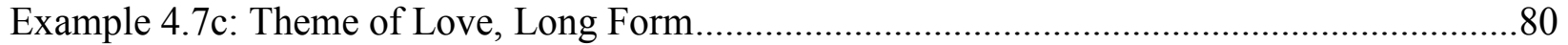

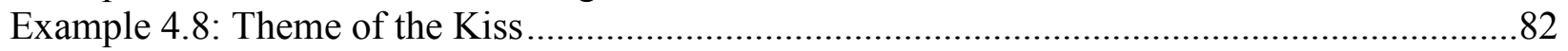

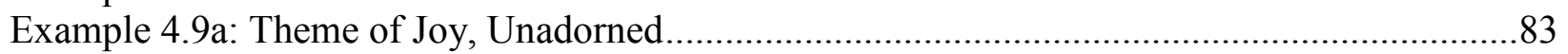

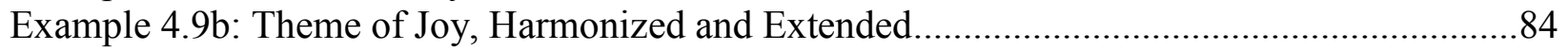

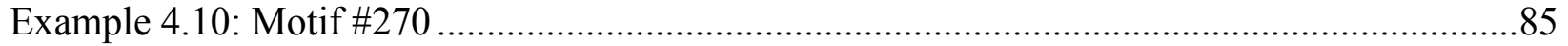

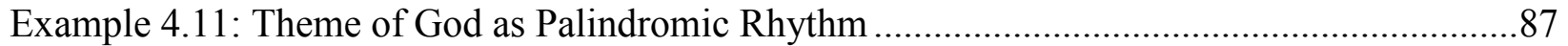

Example 4.12: Nonretrogradable and Palindromic Rhythms in

Rhythmic Canon - Movement IX, "Regard du Temps" ...................................8

Example 4.13: Nonretrogradable Rhythms in Movement XX,

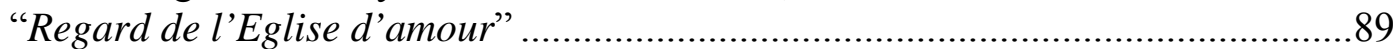

Example 4.14: Numerology Used in Movement III, "L'Echange" ..........................................93 


\section{LIST OF TABLES}

Table 4.1: Mode Seven's Relationships to Other Modes of Limited Transposition ....................72

Table 4.2: Formal Design of Movement II, "Regard de l'Étoile” ...........................................75

Table 4.3: Relationship of Primary and Secondary Themes..................................................78

Table 4.4a: Rhythmic Layout of the Top Lind of "Regards du Fils sur le Fils" ........................91

Table 4.4b: Rhythmic Augmentation of the Middle Stave of

"Regards du Fils sur le Fils" ............................................................................91 


\section{PREFACE}

Introduction and Intent

Throughout the history of Western art music, a number of composers either have been supported financially by religious institutions to create sacred works or have been driven by their own spiritual beliefs to create faith-inspired pieces. With the decrease of Christianity's importance to individuals in Western society throughout time, however, compositions whose genesis arise solely from religious and spiritual inspiration have lessened substantially, or as musicologist Sander van Maas states, "[t]he social process of secularization and the diminished significance of religious practice and theology... have created circumstances in which publicly testifying to the possibility of a musica sacra has become increasingly less acceptable." ${ }^{1}$ This is particularly evident in the music of the Roman Catholic Church from the end of the nineteenth century to the early 1960s, as the Church's liturgical music consisted of a restored Gregorian chant. This eliminated the need for original church compositions, which in turn made composers less inclined to write Catholic religious music during this time.

Although many composers during the twentieth century chose not to write music as a reflection of their faith, one composer, Olivier Messiaen (1908-1992) of France, certainly did not limit his output to secular works. Rather, the majority of Messiaen's oeuvre could be considered a projection of his profound faith, as individual elements within these works belong to larger compositional processes and theories he devised to represent his interpretation of the teachings of the Catholic Church. Although not from a particularly religious family, Messiaen was a devout Catholic throughout his life, selectively choosing specific doctrines of the Church to

\footnotetext{
${ }^{1}$ Sander van Maas, The Reinvention of Religious Music: Olivier Messiaen's Breakthrough Toward the Beyond (New York: Fordham University Press, 2009), ix.
} 
convey in his works. Scholar Roberto Fabbi states that Messiaen's aesthetics and ideas are "root[ed]...in the spiritual beliefs of a man who thinks of himself not only as a Catholic, but also a Catholic Musician, and even a Theologian-Musician." ${ }^{2}$ Robert Sherlaw Johnson goes further to state that the composer's main concern was to inform his audience of his Catholic faith in terms of redemption through the Incarnation and Sacrifice of Christ, quoting Messiaen as saying

The first idea that I wish to express, the most important because it is placed above all else, is the existence of the truths of the Catholic faith. I have the good fortune to be a Catholic; I was born a believer and so it happens that the sacred texts have struck me even from my earliest childhood. A certain number of my works are destined therefore to highlight the theological truths of the Catholic faith. This is the main aspect of my work, the most notable, without doubt the most useful, the most valid, the sole aspect which I will not perhaps regret at the hour of my death. ${ }^{3}$

The "theological truths" upon which Messiaen chose to focus were selected Biblical texts that address the Nativity, the Transfiguration, and the Ascension of Jesus, as well as the Holy Sacrament. ${ }^{4}$ These teachings share in common a demonstration of God granting grace and salvation to humankind by offering Christ as a sacrifice for redemption of sin.

Because of the doctrines he chose to present musically, Messiaen oftentimes found himself embroiled in controversy with religious scholars who accused him of following what religious scholar John G. Strelan describes as a theology of glory (theologia gloriae), defined as "a speculation on the nature of God on the basis of his work in creation or on the basis of human experiences of the divine... it refuses to acknowledge the reality and gravity of sin in the human soul, [and] it does not suspect that such a 'God' is something other than the true God," an

\footnotetext{
${ }^{2}$ Roberto Fabbi, “Theological Implications of Restrictions in Messiaen's Compositional Processes," in Messiaen's Language of Mystical Love, ed. Siglund Bruhn (New York: General Music Publishing, 1998), 56.

${ }^{3}$ Robert Sherlaw Johnson, Messiaen (Berkeley: University of California Press, 1975), 40.

${ }^{4}$ Paul Griffiths, 'Messiaen, Olivier (Eugéne Prosper Charles)', Grove Music Online, ed. L. Macy. (Accessed 28 November 2007), http://www.grovemusic.com.
} 
orientation which ignores a basic precept of Roman Catholic theology. ${ }^{5}$ By this definition, it is true that Messiaen chose to focus on God as a Creator whose love knows no bounds, while His creatures show nothing but endless gratitude for God's love, particularly in His gift of Jesus Christ as Savior. ${ }^{6}$ Messiaen explained why he chose to focus on such a blissful philosophy during an 11 June 1972 discussion with musicologists and theologians that took place on the occasion of the European premiére of Meditations sur le Mystére de la Sainte Trinité, stating that "on the one hand, there are people whose views of the next world is obstructed by the suffering on Earth... On the other hand there are those who, despite suffering, continually assert afresh their hope for everlasting life."7 In another discussion, Messiaen said the essence of his beliefs "is a relationship with an extraordinary spirit which is outside everything... God - as distant, as terrible, as motionless, as eternal, and as infinite as He appears to us, came to us and tried to make Himself comprehensible in our language, in our sensations, in our attitudes of mind."8 Messiaen's viewpoint tended to concentrate on God's accessibility to humans as a loving Father.

Other scholars argue that Messiaen's devotion to enlarge upon these specific Catholic teachings actually stems from the way his faith is entwined with his belief in fairy tales and fantasy, as attested by his fondness for Shakespeare tragedies and Bible stories. ${ }^{9}$ Messiaen described it in this manner:

[T] he Marvelous is inscribed in myths, in tales of fantasy and imagination, whereas in the Catholic faith the Marvelous that is given is real. It is a Marvelous that one can lean on. In this way I have gradually... entered the state of being a believer. One can say I unwittingly passed over from the surreal of fairy tales to the

\footnotetext{
${ }^{5}$ John G. Strelan, “Theologia Crucis, Theologia Gloriae: A Study in Opposing Theologies," Lutheran Theological Journal 23, no. 3 (December 1989): 101.

${ }^{6}$ Siglund Bruhn, "Religious Symbolism in the Music of Olivier Messiaen," The American Journal of Semiotics 13 , no. 3 (Fall 1996): 277-8.

${ }^{7}$ Almut Rossler, Contributions to the Spiritual World of Olivier Messiaen, (Duisburg, West Germany: Gilles and Francke Verlag, 1986): 52-3.

${ }^{8}$ van Maas, 18 .

${ }^{9}$ van Maas.
} 
supernatural of faith. ${ }^{10}$

Messiaen's devotion to introducing listeners to this established belief also affirms part of the Catholic commitment that calls for the laity to work for Christ in three different roles: with a priest-like quality, by offering prayers and works as one's spiritual sacrifice; in a prophet-like way, by offering one's words and testimony of life through ordinary circumstances of the world; and in a royal manner, by mastering one's self and ensuring worldly institutions conform to the norms of justice. ${ }^{11}$ According to musicologist Andrew Shenton, "Messiaen constantly declared his work to be spiritual sacrifice, and his music became testimony to his loyalty in the ordinary world by asserting publicly and repeatedly his unwavering faith," while his dedication to his music and generosity shown to other young musicians serves as evidence of his own selfmastery. $^{12}$

As Messiaen's compositions continued to evolve throughout his lifetime, his commitment to enlighten the audience to his beliefs remained central. Several principal aspects of his compositional technique are inextricably linked to his religious philosophy. The genesis of these practices must be explored, not only as a product of Messiaen's faith, but perhaps as a force of modernism, as composers were challenged more than at any other time in history to devise unconventional means to express themselves.

Messiaen's musical expression is centered on the development of three elements (rhythm, harmony and form) in conjunction with each other. ${ }^{13}$ The composer used these components to create, in the words of musicologist Paul Griffiths, "self-contained blocks," or sizeable segments,

\footnotetext{
${ }^{10}$ van Maas, 18-19.

${ }^{11}$ Andrew Shenton, Olivier Messiaen's System of Signs: Notes Toward Understanding His Music, (Boston, MA: Ashgate Publishing, 2008), 18.

${ }^{12}$ Shenton.

${ }^{13}$ Christopher S. Bowlby, Vingt Regards sur l'Enfant Jesus: Messiaen's Means of Conveying Extra-Musical Subtext (Seattle: University of Washington, 2005), 2.
} 
to force a continuity: large-scale forms are made up of distinct portions containing either repetitive or mirror sequences using either syncopated rhythms or a "stasis" of rhythm. ${ }^{14}$ These were then combined with either a suspended or a quickly changing harmonic pulse. ${ }^{15}$ By fusing these elements together, Messiaen was able to interweave the different religious images and teachings he wished to convey in a unique and original fashion.

The specific works I intend to cover in this paper include Quatuor pour la fin de Temps (1940-41) for piano, clarinet, violin, and cello; Visions de l'Amen (1943) for two pianos; and Vingt Regards sur l'Enfant Jésus (1944) for solo piano. These works were written in a decade noteworthy for the absence of organ compositions, unlike the periods preceding and following this one, in which a majority of organ pieces make up his oeuvre. Also remarkable is how Messiaen focused on writing a number of sacred works "designed for the orchestral auditorium or the recital room."16 Moreover, these three works exemplify those qualities by virtue that they are large-scale works with orchestral-like textures despite the fact that two are for piano and the third for a quartet of instruments.

The historical period in which these pieces were composed is particularly noteworthy, since a religious awakening was taking place in the French cultural and spiritual environment, a clear reaction against the secularism that pervaded the country after the French Revolution. ${ }^{17}$ This spiritual renewal helped Messiaen to establish the beliefs that were to be featured in his works.

While France's period of spiritual enlightenment (the "renouveau littéraire

\footnotetext{
${ }^{14}$ Griffiths, Grove Music Online.

${ }^{15}$ Griffiths.

${ }^{16}$ Griffiths.

${ }^{17}$ Siglund Bruhn, Incarnation: Musical Symbols of Faith in the Two Great Piano Cycles of the 1940s, (Hillsdale, NY: Pendragon Press, 2007): 21.
} 
catholique ${ }^{18}$ ) took place during this time, one major event during this time period influenced Messiaen's compositions as well: World War II. Shortly after the war broke out in France, Messiaen was drafted into military service. Subsequently he was captured in 1941 and sent to a prisoner-of-war camp, Stalag VIII A, in Silesia, Germany. This experience inspired him to write perhaps his most famous and dramatic chamber work, the Quatuor pour la fin de Temps. At the top of the completed score, Messiaen inscribed the following, which evidences the strength of his faith as he attributes the Book of Revelation: "In homage to the Angel of the Apocalypse, who lifted his hand toward heaven, saying, 'There shall be time no longer.' ",19

While the sole inspiration of the Quatuor came from Messiaen's captivity during World War II, Vingt Regards sur l'Enfant Jésus was originally commissioned to be part of a radio program intended to accompany Douze Regards, a set of poems about the Nativity written by Maurice Toesca. ${ }^{20}$ The plan for the radio program was later cancelled, however, because the scope of Messiaen's composition, at the time his largest work to date, far exceeded the time limit of the show.

As Vingt Regards was intended to be a commission, so too was the composition entitled Visions de l'Amen. It was to be performed with pieces by other composers at the third Concert de la Pléiade, a five-concert series organized by film director Denise Tual which took place between February and June $1943 .{ }^{21}$ Visions was originally programmed to take place on 3 May $1943 ;{ }^{22}$ however, because of the breadth of the piece, it was rescheduled to be premiered a week later on 10 May in a concert completely devoted to its sole performance. Despite the secular setting for

\footnotetext{
${ }^{18}$ Bruhn.

${ }^{19}$ Alex Ross, The Rest is Noise, (New York: Picador, 2008), 390.

${ }^{20}$ Peter Hill and Nigel Simeone, Messiaen, (New Haven, CT: Yale, 2005), 134.

${ }^{21}$ Nigel Simeone, "Messiaen and the Concerts de la Pléiade: 'A Kind of Clandestine Revenge Against the Occupation," Music and Letters, 81, no. 4: 554.

${ }^{22}$ Hill and Simeone, 121-2, 126.
} 
the première of the work, Visions shows the depth of Messiaen's faith, one reflecting the influence of the French Catholic writer/philosopher Ernest Hello and Irish-French Benedictine abbot Dom Columba Marmion. ${ }^{23}$ Although relatively unknown today, they helped shape religious thought in France in the early to mid-twentieth century, as they wrote "meditations on [B]iblical texts with an accent on specific terms that highlight essential aspects of the relationship between humans and God or humans and Christ.",24

The conclusion of this compositional period is clearly distinguished, Griffiths contends, by the fact that Messiaen in 1950 began to write music for electronic media or to try his hand at serial harmony. ${ }^{25}$ Indeed, closer examination of Messiaen's works reveals the composer experimenting with new techniques to express himself. While some works still convey his views of Catholic theology to his audience, they do not make up the majority of his oeuvre during this period.

In order to address the issues at hand, this paper shall be laid out in the following manner. Chapter 1 will consist of a biography of the composer, which covers Messiaen's life up to the time he wrote Vingt Regards sur l'Enfant Jésus in 1944. I will also include in this chapter a background of his religious beliefs and a discussion of how these ideas evolved throughout his lifetime.

Following the discussion of Messiaen's life and beliefs I will examine each piece (in compositional order) in Chapters 2, 3, and 4. Specifically, I will discuss their genesis, focusing on the inspiration of these pieces. I will specifically investigate the evidence that points directly to the composer's interpretation of selected Catholic doctrine, examining the individual

\footnotetext{
${ }^{23}$ Siglund Bruhn, Incarnation: Musical Symbols of Faith in the Two Great Piano Cycles of the 1940s, (Hillsdale, NY: Pendragon Press, 2007): 71.

${ }^{24}$ Bruhn.

${ }^{25}$ Ross, 390.
} 
compositional elements that allowed Messiaen to express these beliefs within the work itself. One can conclude from the analysis of the available literature that scholars believe Messiaen's profound devotion to certain Church doctrine cannot be separated from his compositional style. As Roberto Fabbi explains, “[through his] compositional technique, Messiaen sought to transmit both the wonder of faith and theological speculation on its foundation." ${ }^{26}$ The overwhelming majority of scholarly articles written about Messiaen's piano compositions during the 1940s do not attempt to separate the compositional characteristics of the music from their theological elements.

Scores and recordings of the works to be discussed here are readily available, including those that feature the composer performing as a featured pianist. I have also included a bibliography of works that deal specifically with this topic, as well as scholarly research that detail Messiaen's life.

\footnotetext{
${ }^{26}$ Fabbi, 56.
} 


\section{Chapter 1}

Olivier Messiaen's Early Life, the Evolution of His Theological Values, and Their Impact on His Compositions: 1908-1944

The advent of the twentieth century brought about many conceptual changes to the lush late-period Romantic style that prevailed at the end of the nineteenth century. In reaction to this, some composers would return to traditional forms and practices but inject creativity by employing different harmonic styles, a style that came to be known as neoclassicism. Composers from Igor Stravinsky to the members of Les Six embraced the style's balance and restraint, as it offered something fresh compared to the clichéd and overtly emotional gestures of the late Romantic period.

However, as much as this new style was lauded for its moderation, others found neoclassicism too limiting to serve as a vehicle for self-expression. Le jeune France, a group of like-minded composers in the mid-1930s, defied the austerity and objectivity of neoclassicism, instead choosing to write music that espoused passion and emotion. One of the group's members in particular, Olivier Messiaen, purposely turned his back on neoclassicism, as he found it extremely difficult to demonstrate to the listener the depth of his Catholic faith and the vastness of God, which he defined as his most important goal in composing. Thusly, Messiaen followed a new direction in order to communicate his faith through his music. Among the early compositions that resulted from this new process of development are Quatuor pour la fin du Temps, Vingt regards sur l'enfant Jésus, and Visions de l'amen, all of which will be researched in this document.

Olivier Eugéne Prosper Charles Messiaen was born on 10 December 1908, in Avignon, France, son of Pierre, an English teacher, and Cécile Sauvage, a poet. His parents' literary background influenced Messiaen early in his life, as he developed a penchant for fairy tales, 
poetry, and Shakespeare. ${ }^{1}$ In a BBC2 television program that aired on his $80^{\text {th }}$ birthday, the composer credited his mother for bestowing upon him his artistic sense, claiming a set of poems she wrote while pregnant with him, titled L'Âme en bourgeon, had "certainly influenced me, not only my destiny, but also my way of thinking. It gave me a sense of wonder." ${ }^{2}$ Indeed, Cécile's writings seem to anticipate the gifts that her son would later demonstrate:

O mon fils, je tiendrai ta tête dans ma main, Je dirai: j'ai pétri ce petit monde humain; Sous ce front dont la courbe est une aurore etroite J'ai logé l'univers rajeuni qui miroite Et qui lave d'azur les chagrins pluvieux. Je dirai: j'ai donné cette flamme á ces yeux, J'ai tiré du wourire ambigu de la lune Des reflets de la mer, du velours de la prune

Ces Deux astres naïfs ouverts sur l'infini. Je dirai: j'ai formé cette joue et ce nid De la bouch où l'oiseau de la voix se démène; C'est mon oeuvre, ce monde avec sa face humaine.

O mon fils, je tiendrai ta têdans ma main Et, songeant que le jour monte, brille et s'éteint, Je verrai sous tes chairs soyeuses et vermeilles Couvertes d'un pétale à tromper les abeilles, Je verrai s'enfoncer les orbites en creux, L'ossature du nez offrir ses trous ombreux, Les dents rire sur la mâchoire dévastée...

Et ta tête de mort, c'est moi qui l'ai sculptée
O my son, I'll take your head in my hand, And I'll say: this small human world I planned; This brow as it traces the line of first dawn Conceals a whole universe I placed, new born, To mirror, to water the sky when he cries. And I'll say: I gave that flame to his eyes, I drew from the moon's ambiguous smile, From sea glints and from plum's velvet pile

Two stars that stay at endlessness addressed. And I'll say: I formed that cheek and that nest Of a mouth, where his voice stirs like a bird; This man-faced world arose to my word.

O my son, I'll take your head in my hand, And thinking the day grow, brighten, expand, I'll see beneath this rose silk of your flesh, Whose petal cover might the bees enmesh, I'll see orbits plunging into the void, Teeth grin in ranks on a jaw destroyed, Ossature of nose with shadows gaping...

Your death's head: that too is my shaping

In interviews, Messiaen also highlighted several lines from some of his mother's other poems that emphasize the prophecies that foretold of the child within her womb, such as "I suffer from an unknown, distant music" and "The anguish of art's mysteries will be dispersed." ${ }^{3}$ The composer may have been able to find inspiration from his mother's poetry regardless of the

\footnotetext{
${ }^{1}$ Christopher Dingle, The Life of Messiaen (New York: Cambridge University Press, 2007): 1-2.

${ }^{2}$ Dingle, 2.

${ }^{3}$ Dingle, 2.
} 
career path he chose, yet he could not ignore it because she read these poems aloud to Messiaen when he was a mere eight years old, pointedly telling him that it was written by her for him. ${ }^{4}$

While the profundity of his mother's poetry had a strong impact on the future composer, he too had much to credit to his father, Pierre, a well-known translator of Shakespeare's works, for the composer possessed a great love for the playwright's works. He would refer to his own childhood fascination of designing miniature theatrical sets and act out different Shakespeare plays. ${ }^{5}$

Pierre Messiaen did not keep his family long in Avignon, as he was appointed to a teaching post at a secondary school in Ambert, in the south central portion of France, where they remained until 1914. With the onset of World War I, he joined the French army, while Madame Sauvage moved the composer and his younger brother, Alain, born in 1912, to live with her mother, father, and brother in Grenoble, located in the Rhone-Alpes region of southeastern France. ${ }^{6}$ It was here that Messiaen first became enamored with the beauty of the foothills of the French Alps, a love of which would influence him throughout his life. Here, too, was where the composer also began to teach himself to play piano and write music. ${ }^{7}$

At the conclusion of the war in November 1918, the family reunited, and the Messiaens moved to Nantes for a six-month period. ${ }^{8}$ Although their residence in the city was brief, it made a lasting impact upon the budding composer, as he began his formal music training with Véron Arcouët in piano and Jehan de Gibon in harmony. Gibon's tutelage particularly had a profound impact as the teacher introduced Messiaen to the works of Debussy, specifically Pélleas et

\footnotetext{
${ }^{4}$ Dingle, 2.

${ }^{5}$ Bernard Gavoty, “Who Are You, Olivier Messiaen?” Tempo 58 (1961): 34.

${ }^{6}$ Peter Hill and Nigel Simeone, Messiaen (New Haven, CT: Yale University Press, 2005): 12.

${ }^{7}$ Hill and Simeone, 12-13.

${ }^{8}$ Dingle, 10.
} 
Mêlisande. ${ }^{9}$

After the Messiaens' six-month stay in Nantes, Pierre Messiaen was offered a position at the Lycée Charlemagne in Paris, for which the family moved to the city. At the age of eleven, the young composer began his studies at the Paris Conservatoire, auditing classes until he was formally enrolled as a student the next year. ${ }^{10}$ His teachers included Georges Falkenberg (piano), Paul Dukas (composition), Jean Gallon (harmony), Maurice Emmanuel (music history), and Marcel Dupré (organ and improvisation). ${ }^{11}$ Their collaboration with Messiaen ensured a fruitful tenure for the composer, as he won several prizes, including the Première mèdaille de piano (1922), Dieuxéme prix d' harmonie (1924), Première prix d'histoire (1928), Première prix d'orgue (1929), and the Première prix de composition (1930). ${ }^{12}$ Even more valuable to Messiaen was the inspiration these teachers would provide over his lifetime: from both Dupré and Dukas, a fondness for modalities, virtuosity, and artistic conscience; from Emmanuel, knowledge of the Christian liturgies and the modes and meters of ancient Greece. ${ }^{13}$

Although Messiaen enjoyed success as a student, the route he took to becoming a composer was painstakingly slow, because he "had decided that he should... [learn] the various components of his craft, before devoting himself to his chosen profession." ${ }^{14}$ During his first five years at the Conservatoire, he wrote only one substantial piece, a setting of two François Villon poems for voice and piano. ${ }^{15}$ The composer did not begin to write regularly until after his mother's death and his subsequent entrance into Paul Dukas's composition class in $1927 .{ }^{16}$ That changed, however, as Messiaen gained confidence in his abilities and slowly worked through the

\footnotetext{
${ }^{9}$ Dingle, 10.

${ }^{10}$ Hill and Simeone, 16.

${ }^{11}$ Griffiths, Grove Music Online.

${ }^{12}$ Hill and Simeone, 17.

${ }^{13}$ Griffiths.

${ }^{14}$ Dingle, 15.

${ }^{15}$ Dingle.

${ }^{16}$ Dingle.
} 
process of mourning his deceased mother. By the end of the 1920s, Messiaen had written two works, which have come to be regarded by scholars as his earliest mature compositions: Le banquet céleste (1928) for organ and a set of eight Preludes (1928-9) for piano. Both of these compositions display the characteristics of what would later become trademarks of the composer's style. Le banquet céleste was Messiaen's first piece based on a religious theme to be published; it delves into the Catholic belief that during the course of Holy Communion in which the transubstantiation of bread and wine into Jesus Christ's actual body and blood takes place. The Preludes, on the other hand, include his first portrayal of nature as evidenced in the first Prelude, "La colombe" (literally, "The Dove"), and also explores the struggle between life and death in the sixth Prelude,"Cloches d'angoisses et larmes d'adieu" ("Bells of Anguish and Tears of Farewell"). ${ }^{17}$

The Preludes gained the attention of the publisher Durand, giving him a newfound confidence in his music. Messiaen graduated from the Conservatoire in 1930, and by September of the next year, won the position of principal organist for La Trinité in Paris, a post he was to hold for over 60 years. ${ }^{18}$ Perhaps the privilege of playing one of the finest organs in Paris provided him the impetus to compose for the instrument. Indeed, a number of his major compositions for organ were written within a five-year period of his taking the post. ${ }^{19}$ More importantly, the pieces written during this interval served a sole purpose, "to manifest the doctrines of the Christian faith," which was to remain a focus of his music for the rest of his life. $^{20}$

Another component of the composer's personal theology that inspired his compositions at

\footnotetext{
${ }^{17}$ Dingle, 22-4.

${ }^{18}$ Griffiths.

${ }^{19}$ Griffiths.

${ }^{20}$ Griffiths.
} 
this time was human love within the perspective of the sacrament of marriage. ${ }^{21}$ Inspired by his marriage to violinist and composer Claire Delbos in June 1932, Messiaen wrote Thème et variations (1932) for violin and piano as a wedding present to her. The composer's devotion to his wife was evident in his painstaking process to compose another piece dedicated to their love, as Messiaen took four years to complete Poèmes pour Mi (1936) for soprano, piano, and orchestra. The piece in its final form goes beyond the dedication to Claire in the title ("Mi" was Olivier's pet name for her), as he "juxtapos[ed]... the language of heartfelt religious devotion... alongside personal revelations about life with Claire." 22

While both Thème et variations and Poèmes pour Mi were written specifically with Claire in mind, Messiaen composed Chants de terre et de ciel (Songs of Earth and Sky) (1938), a song cycle for soprano and piano, to celebrate the birth of his son Pascal, his only child, in 1937." 23 Originally the work was titled Prismes: Six poémes d'Olivier Messiaen (Prisms: Six Poems of Olivier Messiaen), which was "intended to describe the way the spiritual dimension of marriage...[and parenthood as] viewed from different perspectives." ${ }^{24}$ Indeed, the song cycle first depicts Messiaen's devotion to Claire in a love song ("Bail avec Mi", or a promise made to Mi), then as "an object of contemplation by an angel" ("Antienne du silence", or antiphon of silence). ${ }^{25} \mathrm{He}$ also signifies his love for Pascal by including what Messiaen termed "a nursery rhyme" as the third song of the cycle, "Danse du bébé-Pilule" (Dance for "bébé-pilule", the pet name for his son), and lauds his son's “exuberant and unbounded enchantment in childhood” in “Arc-en-ciel d'innocence" (Rainbow of Innocence). ${ }^{26}$

\footnotetext{
${ }^{21}$ Griffiths.

${ }^{22}$ Dingle, 50.

${ }^{23}$ Dingle, 52.

${ }^{24}$ Hill and Simeone, 79.

${ }^{25}$ Hill and Simeone, 80.

${ }^{26}$ Hill and Simeone, 81 .
} 
As evidenced in his compositions, the serenity that family life afforded Messiaen was somewhat contrary to his more active role in promoting new music in France at the time. French composers were writing works wholly espousing the ideals expressed by the neo-Classicists of the time, notably Erik Satie and the more successful members of Les Six as well as Russian émigré Igor Stravinsky. In reaction to the popularity of neoclassicism, Messiaen, along with his wife and fellow composers Simon Jolivet, Jean Yves Daniel-Lesur, and Yves Baudrier, formed Le jeune France, a group having "a common desire to be satisfied with nothing less than sincerity, generosity, and artistic good faith... a living music." ${ }^{27}$ From 1936 to 1939, the group gave concerts of pieces that featured different compositional styles, yet were united in the fact that they "signaled a clear aversion to neoclassicism." ${ }^{28}$ Messiaen made many painstaking efforts to have his group's music performed, as finding patrons to sponsor these events was not easy. These struggles, however, would not compare to the trials he was to face in the next few years, as France declared war on Germany on 3 September $1939 .{ }^{29}$

Messiaen had to abandon the comforts of civilian life as he was called up to serve the army. While he dutifully took his assignment, his wife and son took up residence at Neussargues in the south central portion of the country in order to be closer to her mother and sister. ${ }^{30}$ The rigors of military life proved difficult for the composer, although some would say the army was more lenient on him than on his fellow compatriots. Because of his poor eyesight, Messiaen did not take up a combat role, although he was very close to the front lines, ${ }^{31}$ serving as a hospital attendant. ${ }^{32}$ The composer enjoyed some other privileges as well, according to letters he wrote in

\footnotetext{
${ }^{27}$ Hill and Simeone, 63.

${ }^{28}$ Hill and Simeone, 64.

${ }^{29}$ Hill and Simeone, 85 .

${ }^{30}$ Hill and Simeone, 86 .

${ }^{31}$ Dingle, 68.

${ }^{32}$ Robert Sherlaw Johnson, Messiaen (Berkeley, CA: University of California Press, 1975): 11.
} 
1940 to the journal L'Orgue detailing his life as a soldier. Messiaen was allowed to keep pocket scores of Beethoven symphonies, Ravel's Ma mére l'oye, Stravinsky's Les noces, and Honegger's Horace victorieux, which he studied late at night. He was even given the privilege of playing organ on some Sundays. ${ }^{33}$

The few luxuries afforded to Messiaen by his commanding officers would sadly come to an end, as the German army began its occupation of northern France in 1940. On 20 June of that year, Messiaen, along with two musicians he had met, clarinetist Henri Akoka and cellist Étienne Pasquier, were captured and taken as prisoners of war to Stalag VIIIA at Görlitz in Silesia. ${ }^{34}$ Within a short time of their detention, the trio came upon another musician, violinist Jean Le Boulaire.

The four men made fast friends, and the German troops were somewhat less strict on them, as they allowed both Akoka and Le Boulaire to keep their instruments, found a cello (unfortunately, according to Messiaen, with a missing string) for Pasquier, and supplied Messiaen with manuscript paper and writing instruments to compose. ${ }^{35}$ By giving special privileges to these prisoners, the German guards could mitigate the monotony of routine at the prison camp, as the musicians were able to give a few performances to their fellow inmates. ${ }^{36}$ Although the performances offered a break from the mundane, they only gave a brief respite from the deplorable conditions at the camp. Prisoners experienced bitter cold during the winter of 1940-41, and food shortages were typical. This backdrop further fueled the creativity that was to spawn the Quatuor pour la fin du Temps. ${ }^{37}$ According to some accounts of his captivity, Messiaen is said to have fainted from hunger, and along with the harsh weather, he

\footnotetext{
${ }^{33}$ Hill and Simeone, 91.

${ }^{34}$ Dingle, 68-70.

35 Johnson, 61.

${ }^{36}$ Dingle, 70.

${ }^{37}$ Dingle, 70.
} 
would have "vivid colored dreams, reminding him of the vibrant, often violent imagery of the Apocalypse, with its rainbow-encircled angels heralding the end of time." When he caught sight of the aurora borealis one early morning, he thought his visions were coming true. ${ }^{38}$ Inspired, Messiaen created the piece, which originally consisted of a single movement he had composed earlier that winter for Pasquier, Akoka, and Le Boulaire, to which he added seven other movements. ${ }^{39}$ Writing the music was therapeutic for Messiaen, as he recalled in an account of the war, "[it gave me an opportunity] to escape from the snow, from the war, from captivity, and from myself... in the midst of 30,000 prisoners, I was probably the only man who was not one. $" 40$

The Quatuor became one of his most substantial compositions to date. With the permission of the German guards, the first public performance was given on the evening of 15 January 1941, meeting great success. ${ }^{41}$ The premiére of the piece raised the morale of the captives, but more importantly, the senior officers who listened to the rehearsals apparently felt that the performance warranted further reward: freedom for the musicians. Pasquier recalled later in his life that the captain in charge spoke to Messiaen after one rehearsal, saying, "In a few weeks, there will be a return of prisoners to Paris. Don't miss the train," as the senior officers believed that the quartet's status as musicians meant they were unarmed and therefore not dangerous. ${ }^{42}$ By March of that year, Messiaen was free.

After his release from captivity, Messiaen had a difficult time adjusting to family life as it became painfully obvious that Madame Messiaen was suffering from the symptoms of early dementia, which may have partially resulted from the trauma she suffered after several

\footnotetext{
${ }^{38}$ Dingle.

${ }^{39}$ Dingle, $70-1$.

${ }^{40}$ Dingle, 74 .

${ }^{41}$ Dingle, 73.

${ }^{42}$ Dingle 74.
} 
miscarriages she had early in their marriage. ${ }^{43}$ The burden of raising their only son rested heavily on Messiaen as his wife gradually became unable to perform the most menial of tasks. Although tormented by his wife's deteriorating mental health, the composer remained completely devoted to her, even as she was later committed to an asylum, where she died in $1959 .{ }^{44}$

While struggling to take care of his wife and son, Messiaen resumed his duties as organist at Trinité, from which he made modest earnings. He was later able to secure a position as a teacher of harmony at the Paris Conservatoire. The Conservatoire during the Occupation was but a shadow of its former self, as most of the staff and students had fled the city on the day the Germans arrived. ${ }^{45}$ Only seven faculty members and twenty-five students remained, the majority of the latter comprised of women as most of the men were sent to war. ${ }^{46}$ Among the students there that Messiaen taught included a gifted young pianist, Yvonne Loriod.

The importance of Loriod in Messiaen's life cannot be overlooked, as she became a champion of his works, his muse, and after Madame Messiaen's death, his second wife. Although there was much conjecture about their relationship while Madame Messiaen was alive, all available evidence indicates it was entirely platonic. ${ }^{47}$ Throughout this time period, Messiaen remained devoted to his Roman Catholic faith as well as to his marriage vows; he did become "emotionally close" to Loriod, however. ${ }^{48}$ The only way he could express the growing feelings he had for Loriod was through his music. ${ }^{49}$

With Loriod's pianistic abilities in mind, Messiaen wrote two major piano works, both of which are studied in detail in this document: Visions de l'Amen (1943) for two pianos, which

\footnotetext{
${ }^{43}$ Hill and Simeone, 157.

${ }^{44}$ Dingle, 101.

${ }^{45}$ Dingle, 75.

${ }^{46}$ Dingle.

${ }^{47}$ Dingle, 101.

${ }^{48}$ Dingle.

${ }^{49}$ Griffiths.
} 
they premiered together, and Vingt Regards sur l'Enfant Jésus (1944) for solo piano. Also during this time, the composer wrote Technique de mon langage musical (1944). This major work allowed Messiaen to explain his "aesthetic and technical concerns that underpinned his musical choices at the time," with a great deal of the book devoted to rhythm. ${ }^{50}$ By publishing the book, the composer was able to cultivate a following among students, of which included (unsurprisingly) Loriod and ultimately of greatest significance, Pierre Boulez. ${ }^{51}$ This growing discipleship enabled Messiaen to remain a dominant force in the French music community for years to come.

\section{Messiaen's Religious Beliefs}

Messiaen's personal theology most definitively was a product of a combination of the religious environment in which he was raised as well as the works of the philosophers he studied. For the French Catholic Church, the country's religious landscape changed during the midnineteenth to early twentieth centuries, the origins of which lie in the dramatic transformation of the French public's opinion of the Church following the country's sound defeat in the FrancoPrussian War (1870-1871). France’s Third Republic (1870-1940) gradually began to establish what appeared to be an anticlerical agenda in order to reduce the Church's influence on the government. ${ }^{52}$ These actions included the banning of the Jesuit order from France in 1880, the disallowing of religious education in French public schools in 1882, the severing of relations between the Vatican and the French government in 1904, followed inevitably by the passing of legislation mandating the separation of church and state. ${ }^{53}$

While the Church seemed to be under attack by those in the French government and the

\footnotetext{
${ }^{50}$ Dingle, 78.

${ }^{51}$ Dingle, 79.

52 Andrew Shenton, Olivier Messiaen's System of Signs: Notes Towards Understanding His Music, (Burlington, VT: Ashgate Publishing, 2008): 19-20.

${ }^{53}$ Shenton, 19-20.
} 
public sector, French Catholic congregations also witnessed a decline in Mass attendance, while the general French population became less religious with roughly only a third of those baptized attending church on Sundays. ${ }^{54}$ Facing dwindling numbers and lessening public support, French Catholics had to change the religious landscape or face possible extinction. Both clergy and that portion of the laity not alienated from the Church took different approaches in respect to reversing the public's tendency towards religious indifference. Lay people sought to focus their efforts on a spiritual renewal of the individual, which called for a return to the "ideal[s] of the early church ... advocat[ing] the spiritual sources of the gospels." ${ }^{, 55}$ With this basic principle in mind, the proponents of le renouveau litéraire catholique, active from 1880 to 1914, were united under the belief that "literary value relies above all on religious foundation and that significant literature is thus necessarily a literature of faith." 56 Therefore, faith ought to arise as the center of creativity, resulting in a "religious symbolism in which God takes the place of the idea, ...[as] artistic expression defines itself in constant interaction with religious thinking."

As creativity was the main focus of renouveau litéraire catholique, another movement, le renouveau spirituel, emerged at about the same time, reaching its height in the 1920s. This group, made up of middle- and upper-class Catholics, helped bring to light the works of the great ascetic and mystics such as St. Francis de Sales, St. Teresa of Ávila, and St. John of the Cross. ${ }^{58}$ Proponents believed in a profound spirituality in existence as well as a spiritual marriage of God with humankind, such as that which is depicted in Matthew 25:1-13, the parable in which the wise virgins have brought enough oil for their lamps to wait for the bridegroom's arrival and

\footnotetext{
54 Shenton, 20.

55 Siglund Bruhn, Incarnation: Musical Symbols of Faith in the Two Great Piano Cycles of the 1940 (Hillsdale, NY: Pendragon Press, 2007): 20.

${ }^{56}$ Bruhn, 21.

${ }^{57}$ Bruhn, 22.

${ }^{58}$ Bruhn, 22.
} 
hence are allowed to attend the wedding feast with him. ${ }^{59}$ Proponents of the cause therefore believed that in order to have a complete union with God, one must offer oneself to Him with complete devotion, which "often leads the soul into the lovely regions of ecstasy." 60

While certain members of the laity of the Church (including Messiaen) began their own spiritual renewal, the French clerics in the 1930s followed a parallel strategy to awaken the spirituality of the public, attempting to prevent the further erosion of membership by employing a three-pronged approach. The first of these, a return to social engagement of the impoverished, entailed priests moving outside the cities to experience a life of poverty alongside those in need, much like St. Francis of Assisi, who was well known for his work with the sick and the poor. ${ }^{61}$ The second approach involved revision of the Church's own theology, known as ressourcement (known later as nouvelle théologie), tracing this doctrine to the teachings of Jesus and the early Church, increasing accessibility to the lay communities. ${ }^{62}$ The final method in which the Church brethren believed they could involve the congregation in the celebration of the Eucharist consisted of the Church undergoing its own liturgical renaissance, a return to the original Roman liturgy that was practiced during its first years of formation. ${ }^{63}$

The use of these practices went into effect during the 1930s, a time in which Messiaen, in his twenties, was forming his philosophical and theological beliefs. Aside from these outside factors that had clearly influenced Messiaen, the composer was reluctant to give any impression that those close to him may have held sway over his beliefs. He indicated in several interviews that his personal theology developed in a vacuum because he had had little or no parental guidance in regards to faith. As noted in Robert Sherlaw Johnson's biography of Messiaen, the

\footnotetext{
${ }^{59}$ Bruhn, 23.

${ }^{60}$ Bruhn, 23-24.

${ }^{61}$ Bruhn, 26.

${ }^{62}$ Bruhn, 25.

${ }^{63}$ Bruhn, 26.
} 
composer said unequivocally, "I was born a believer." ${ }^{64}$ However, it has become obvious in musicologist Siglund Bruhn's research that Messiaen indeed was influenced by two important adult figures of his life: his father and Charles Tournemire, a man considered his mentor as organist and was instrumental in Messiaen's securing the post at La Trinité. ${ }^{65}$ However, Messiaen remained mostly silent about the influences that both of these men may have had upon him.

Messiaen's refusal to acknowledge the role his father played in the development of the composer's personal theology is very surprising. In fact, Messiaen's father was a profoundly pious Catholic who was very concerned with the religious education of his sons; as such, he seems to have passed down to the composer his own passion for understanding Catholicism and its demands. ${ }^{66}$ Pierre Messiaen's memoirs describe in detail the man's preoccupation with religion, even voicing his worries over his wife's own lack of spirituality, as she was a woman who had no faith in God. ${ }^{67}$

As Pierre Messiaen's memoirs reflected his strong sense of spirituality, so too did his works as a translator, literary scholar, and his attempts to become an author. His first novel, Jacques Dupré, a story about a man with strong Christian values who encourages youth to open their minds to theology and metaphysics, bears significant similarities to his son's only opera, St. Francois d'Assise, as the dialogues between the novel's characters regarding immortality and divinity could be mistaken for conversations of the saint's companions. ${ }^{68}$ Also, the many French translations of English works Pierre Messiaen published include most notably John Milton's seventeenth-century epic poem Paradise Lost, and Jesuit priest and contemporary Catholic

\footnotetext{
64 Johnson, 40.

${ }^{65}$ Bruhn, 20,

${ }^{66}$ Bruhn, 28.

${ }^{67}$ Bruhn, 28.

${ }^{68}$ Bruhn, 29.
} 
mystic Paul de Jaegher's The Virtue of Love Meditations. ${ }^{69}$

While Messiaen minimized his father's role in the formation of the composer's piety, another father-like figure to the composer, Charles Tournemire, may have been highly influential in the formation of Messiaen's personal theology. Indeed, the similarities between the two men in regards to their spirituality are startling. Both Messiaen and Tournemire were greatly influenced by Ernest Hello (1828-1885), a French essayist and Catholic mystic who rejected René Descartes and the scientific method, choosing instead to espouse the principles of theology and philosophy found in Scripture. ${ }^{70}$ Hello's writings are quoted throughout many of Tournemire's works, as in his lyrical drama Les Dieux sont morts (“The Gods are Dead”, written in 1912), which recounts the legend of the death of the pagan gods that resulted from the birth of Christ. ${ }^{71}$ Similarly, Messiaen's Visions de l'Amen most directly was inspired by Hello's writings, as the piece is based on the last chapter of the author's Paroles de Dieu (Words of God), particularly "the triumphant Amen of the Serene Regions". ${ }^{72}$

While both composers drew upon Hello's writings as inspiration for their works, other evidence of their similarities in faith appear in Messiaen's and Tournemire's individual commentaries in the movements of their major compositions. In the sixth movement of Messiaen's Vingt Regards sur l'Enfant Jésus Messiaen's commentary speaks of “unfathomable extensions of spaces and durations, galaxies and photons," while in movement nine of Tournemire's work Douze Prélude-poèmes pour piano (1931), titled "La méditation sur DieuPère" ("Meditation on God-Father"), the composer speaks of "unfathomable thoughts that engulf

\footnotetext{
${ }^{69}$ Bruhn, 29.

${ }^{70}$ Susan Tracey Otten, “Ernest Hello”, ed. Kevin Knight (Accessed 12 November 2010), http://www.newadvent.org/cathen/16044b.htm.

${ }^{71}$ Stephen Schloesser, Jazz Age Catholicism: Mystic Modernism in Postwar Paris, 1919-1933 (Toronto: University of Toronto, 2005): 292.

${ }^{72}$ Bruhn, 32.
} 
the whole Creation with countless suns." ${ }^{, 73}$ In another example, Tournemire's notes on the eleventh movement of the same work, "Méditation sur l'Esprit Saint" ("Meditation on the Holy Spirit"), mentions, "The Holy Spirit vivifies the great Christian idea. It seeps into the immense vibration of the archetypal ideal," which can be compared to Messiaen's tenth movement of the Vingt Regards, the Regard de l'esprit du joie ("Contemplation of the Spirit of Joy"), in which the composer speaks of a frenzied dance that is inspired by the blessed joy of God and Jesus Christ (“Danse vehemente; ton ivre des cours, transport du saint-esprit; la joie d'amour du Dieu bienheureux dans l'ame de Jesus Christ."). ${ }^{74}$

As the religious influence originating from historical events and environmental factors is evident, it warrants an explanation of the beliefs Messiaen held close to his heart. By most accounts, the composer was a traditionalist, adhering to conservative beliefs that could be construed by outsiders as values espoused by a mystic and not necessarily those universally held by the Catholic Church. ${ }^{75}$ A standard definition of mysticism found in the Merriam-Webster Dictionary states that it is "the belief that direct knowledge of God, spiritual truth, or ultimate reality can be attained through subjective experience," ${ }^{, 76}$ and the composer "[o]n the basis of lucid and speculative theological knowledge, and a predisposition for the visionary... made his music a vehicle, in symbolic terms, for theological visions." ${ }^{77}$ Music historian and critic Wilfred Mellers claims that Messiaen's beliefs are indeed more theosophical than theological, as the composer "in the dictionary sense [has] a knowledge of God by spiritual ecstasy, direct intuition,

\footnotetext{
${ }^{73}$ Bruhn, 33.

${ }^{74}$ Bruhn, 33.

75 Shenton, 23.

76 “Mysticism," Merriam-Webster Dictionary Online (Accessed 12 November 2010), http://www.merriamwebster.com/dictionary/mysticism.

${ }^{77}$ Roberto Fabbi, 'Theological Implications of Restrictions in Messiaen's Compositional Processes," in Messiaen's Language of Mystical Love," ed. Siglund Bruhn (New York: General Music Publishing, 1998), 72.
} 
or special individual relations."78

The labeling of Messiaen as mystic is at best a contentious one, however. According to Robert Sherlaw Johnson, this criticism of Messiaen is without merit: “[Although Messiaen’s] emphasis is to bring mankind into contact with the experience of heaven [and] contemplation of God... [t] he means by which the mystical experience is achieved... is for the individual worshipper or listener [to determine]." ${ }^{79}$ Messiaen also rejected being labeled a mystic, stating that his beliefs were based on theology instead, although it is quite evident that on the strictest of definitions he contradicted himself, as he claimed to have "undergone transforming experiences and to have had an innate understanding of God." ${ }^{80}$ In addition, it is true that "Messiaen was content with the expression of his religious beliefs in terms sanctioned by the Catholic Church." ${ }^{81}$ Also, unlike other mystics, he did not seek out other like-minded individuals who dedicated themselves to "the exploration of certain occult phenomena," as Messiaen's own experiences were "of a purely individual nature, centered in his relationship to God...[and] clearly [he] felt no need for critical or speculative vindications of the religious tenets that he had...[known] since early childhood." ${ }^{, 82}$

As it is extremely difficult for humans to understand the totality of God, Messiaen wrote his music to express, according to the composer, "ideas about a single being, who is God, but a being who is ever-present and who can be found in everything, above everything, and below everything." ${ }^{83}$ With this in mind, the composer made the conveyance of eternity to the listener

\footnotetext{
${ }^{78}$ Shenton, 24.

${ }^{79}$ Robert Sherlaw Johnson, "Rhythmic Technique and Symbolism in the Music of Olivier Messiaen," in Messiaen’s Language of Mystical Love,” ed. Siglund Bruhn (New York: General Music Publishing, 1998), 138.

${ }^{80}$ Shenton, 23.

${ }^{81}$ Shenton, 24.

${ }^{82}$ Bruhn, 37.

${ }^{83}$ Shenton, 29.
} 
his most important goal. ${ }^{84}$ Because realizing a subject of such great magnitude cannot be put into words, Messiaen's music could only capture glimpses of God's completeness.

Although Messiaen was limited representing in his music God's omnipresence, he steadfastly believed in the power the medium had in enhancing the relationship between God and humans, as instrumental music is free from textual constraints of and can better describe the divinity of God to us. ${ }^{85}$ According to Messiaen, "Music leads us to God by lack of truth," meaning that it is a "symbolic representation of an event that isn't really visible, whereas celestial meditation is no longer symbolic: it's a reality. ${ }^{\prime 86}$ As this is the core of Messiaen's philosophy, the following chapters of this research document will investigate the musical symbolism the composer utilizes in order to express his own personal theology.

\footnotetext{
${ }^{84}$ Ian Darbyshire. "Messiaen and the Representation of the Theological Illusion of Time," in Messiaen's Language of Mystical Love," ed. Siglund Bruhn (New York: General Music Publishing, 1998), 35.

${ }^{85}$ Shenton, 30.

${ }^{86}$ Shenton, 29-30.
} 


\section{Chapter 2}

Quatuor pour la fin du Temps and the Hope of Eternity Amid the Apocalypse: How Messiaen's Theology Helped Shape His Musical Language

Messiaen's unwavering Catholic faith enabled him to endure the greatest hardships of his lifetime, of which his imprisonment in Stalag VIII can be considered one of the most difficult. Although many may consider the treatment of the composer and the conditions he faced in Silesia, Germany, to be less grueling than those experienced by prisoners of other World War II internment camps, they nonetheless had a profound impact upon him, forcing him to rely heavily on his beliefs in order to survive.

Indeed, one of the key points to Messiaen's faith was the inspiration he found from a specific text of the New Testament, upon which he would later base the Quatuor: Revelations 10:1-7. The composer provides his own personal conflation of the passage in the notes preceding the piece:

And I saw another mighty angel coming down from heaven, wrapped in a cloud, with a rainbow on his head; his face was like the sun, and his legs like pillars of fire...Setting his right foot on the sea and his left foot on the land... and, standing on the sea and on the land, he raises his right hand toward Heaven and swore by He who lives forever and ever... saying: 'There will be no more Time; but in the days when the seventh angel is to blow his trumpet, the mystery of God will be fulfilled. ${ }^{1}$

To many, this passage contains imagery that could be interpreted as apocalyptic; Messiaen, however, would find in it "a glimmer of hope," often seeking inspiration and consolation as he read and re-read the passage during his captivity, seeing the angel both as "savior and muse.", Indeed, the composer specifically found the angel's words "There will be no more time" to be a

\footnotetext{
${ }^{1}$ Olivier Messiaen, Quatuor pour la fin du Temps, trans. in Rebecca Rischin, For the End of Time: The Story of the Messiaen Quartet (Ithaca, NY: Cornell University Press, 2003): 129.

${ }^{2}$ Rebecca Rischin, For the End of Time: The Story of the Messiaen Quartet (Ithaca, NY: Cornell University Press, 2003): 51 .
} 
signal not only of the end of "the human dimension with cycles and destiny to rejoin eternity," but as a way to join God in a new life that goes beyond what humanity knows. ${ }^{3}$

The triumph of God and humanity uniting in eternity indeed serves as a central purpose of the composition, allowing Messiaen not only a way to preserve his sanity and well-being, but also providing a creative outlet for him to write. The entire format of the work provides evidence of his strong beliefs in the salvation of the Apocalypse, as he chose to include eight movements in the composition. In the preface of the piece, Messiaen explains that he did not come upon this conclusion arbitrarily; rather, the determination was based on his theological notions of perfection: "Seven is the perfect number, the Creation in six days sanctified by the divine Sabbath; the seventh day... extends into eternity and becomes the eighth day of eternal light, of unalterable peace." ${ }^{4}$

Along with the number of movements symbolizing the hope for the end of time, the title and the descriptions Messiaen provides for each section reflect his homage to eternity. As both these literary devices are intertwined with the composer's desire to demonstrate the dissolution of time, so too is the musical structure of the Quatuor, as is made clear by each movement's title and preface as well as the overall organization of the work. A translation of the first part of the composer's preface as it appears in Rebecca Rischin's For the End of Time: The Story of the Messiaen Quartet, is reproduced below:

Conceived and composed during my captivity, the Quartet for the End of Time was premiered in Stalag VIIIA on 15 January 1941, by Jean Le Boulaire, violin; Henri Akoka, clarinet: Etienne Pasquier, cello, and myself at the piano. The Piece was directly inspired by the above passage from Revelation. Its musical language is essentially ethereal, spiritual Catholic. The modes, realizing melodically and harmonically a sort of tonal ubiquity, bring the listener closer to infinity, to eternity in space. The special

\footnotetext{
${ }^{3}$ Rischin, 51.

${ }^{4}$ Messiaen, trans. in Rischin, 129.
} 
rhythms, independent of the meter, powerfully contribute to the effect of banishing the temporal. (But given the awesomeness of the subject, all of the above serves merely as inarticulate and tentative explanation!)

This Quartet comprises eight movements. Why? Seven is the perfect number, the Creation in six days sanctified by the divine Sabbath, the seventh day of this repose extends into eternity and becomes the eighth day of eternal light, of unalterable peace.

\section{Liturgie de Cristal ("Crystal Liturgy"). Between 3 and 4} o'clock in the morning, the birds awaken: a solo blackbird or nightingale improvises, surrounded by dustwhirls of sound, by a halo of harmonics lost high up in the trees. Transpose this onto a religious plane: you have the harmonious silence of heaven.

2. Vocalise pour l'Ange qui annonce la fin du Temps (Vocalise, for the Angel Who Announces the End of Time." The first and third sections (both very brief) evoke the power of this mighty angel, crowned with a rainbow and clothed in a cloud, who places one foot on the sea and the other on the land. The "middle"[second section] evokes the impalpable harmonies of heaven. In the piano: gentle cascades of blue-orange chords, encircling with the distant carillon the plainchant-like song of the violin and cello.

3. Abîme des oiseaux (Abyss of the Birds). Unaccompanied clarinet. The abyss is Time, with its weariness and gloom. The birds are the opposite of Time; they represent our longing for light, for stars, for rainbows, and for jubilant song!

4. Intermède (Interlude). Scherzo, in a more outgoing character than the other movements, yet related to them nevertheless by melodic "recalls."

5. Louange à l'Éternité dé Jésus (Praise to the Eternity of Jesus). Here, Jesus is considered the Word of God. A long phrase in the cello, inexorably slow, glorifies, with adoration and reverence, the eternity of this mighty yet gentle Word, "of which the ages never tire." The melody unfolds majestically, as if from a regal yet soft-colored horizon. "In the beginning was the Word, and the Word was with God, and the Word was God."

6. Danse de la fureur, pour les sept trompettes (Dance of Fury, for the Seven Trumpets). Rhythmically, the most characteristic movement of this series. The four instruments in unison create the effect of gongs and trumpets (the first six trumpets of the Apocalypse followed by various calamities, the trumpet of the seventh angel announcing the fulfillment of the mystery of 
God). Use of added values, augmentation and diminution, and nonretrogradable rhythms. Music of stone, tremendous ringing granite, perpetual motion of steel, of enormous blocks of purple fury of frozen intoxication. Listen, above all, to the terrifying fortissimo of the theme in augmentation and register alteration toward the end of the movement.

7. Fouillis d'arcs-en-ciel, pour l"Ange qui annonce la fin du temps (Tangle of Rainbows, for the Angel Who Announces the End of Time). Certain passages here recall the second movement. The Angel full of might appears, and in particular the rainbow that crowns him (the rainbow, symbol of peace, of wisdom, and of every luminous sound and vibration). In my dreams, I hear and see classified chords and melodies, common colors and forms, then, after this transitory stage, I pass into unreality and lose myself in a rapture to a whirling, a gyrating fusion of superhuman sound and color. These swords of fire, these pools of blue-orange lava, these shooting stars: this is the tangled skein, these are the rainbows!

8. Louange à l'Immrortalité de Jésus (Praise to the Immortality of Jesus." Long solo for violin, the counterpart to the cello solo in the fifth movement. Why this second eulogy" It addresses more specifically the second aspect of Jesus: Jesus the Man, the Word made flesh, immortally resurrected, to impart us his life. This movement is pure love. The progressive ascent toward the extremely high register represents the ascension of man toward his Lord, of the [S]on of God toward his Father, of deified Man toward Paradise.

And I repeat again what I said earlier: "Given the awesomeness of the subject, all of the above serves merely as inarticulate and tentative explanation!",5

As evidenced by the composer's preface, the intention of "bringing the listener closer to infinity" was of prime importance to Messiaen, as was his attempt to depict Revelations 10:1-7 in a "musical language [that] is essentially ethereal, spiritual, [and] Catholic." ${ }^{6}$ Messiaen designed the overall structure of the piece to highlight the importance of eternity. Although musicologist Anthony Pople points out that while the movements in the Quatuor were not conceived in order, the subject matter that is addressed in the prefatory notes helped the

\footnotetext{
${ }^{5}$ Messiaen, trans. in Rischin, 129-131.

${ }^{6}$ Messiaen, trans. in Rischin, 129.
} 
composer to justify the placement of each section, as movements one (Liturgie de Cristal), five (Louange a l'Éternite dé Jésus), and eight (Louange á l'Immrortalité de Jésus) all “frame the [piece, as] each is concerned with the contemplation of eternity."

Although his commentary provided a way for Messiaen to communicate his intentions to the listener, he firmly believed that through music he would be able to convey his religious beliefs. According to Iain Matheson, music is "intrinsically theological," as it concerns itself with "space, time, transcendence, meaning, " as it "depicts itself... to which nothing [including words] can or need to be added." ${ }^{8}$ Therefore, to evoke eternity in which no time exists (i.e., timelessness), the composer's task was to develop a musical language in which he could effectively capture the important tenets of his faith along with the optimism that he found in the Biblical passage.

The elements that comprise the musical language he developed in the Quatuor were so significant that they justified a section of explanatory notes included with the publication of the score; so too they formed the basis of his most significant theoretical treatise of the 1940s, Technique de mon langage musical (1944). Specifically, three ideas - time, color, and birdsong - served as catalysts in developing this groundbreaking musical language and played an important part in influencing several musical elements (melody, harmony, rhythm, form, and texture), which in this chapter will be discussed in the context of these three main ideas.

\section{Time (Rhythm)}

For Messiaen, of utmost importance in depicting the passage from Revelations was evoking eternity. Rhythm took an especially essential role in accomplishing this goal, and the composer developed an intricate rhythmic technique to evoke a feeling of freedom. According to

\footnotetext{
${ }^{7}$ Anthony Pople, , Messiaen: Quatuor pour la fin du Temps (New York: Cambridge University Press, 1998): 10.

${ }^{8}$ Iain Matheson, "The End of Time: a Biblical Theme in Messiaen's Quatuor," from The Messiaen Companion, ed. Peter Hill (Portland, OR: Amadeus Press, 1995): 245-6.
} 
Messiaen, his new rhythmic language employed "[a] secret predilection for prime numbers... the notions of meter and tempo [which] are replaced ...by the feeling of a short note value... and by its free multiplication; also by certain "rhythmic forms," such as: added values, augmentation and diminution, nonretrogradable rhythms, and rhythmic ostinato."9

The first concept Messiaen discussed in this brief explanation of his rhythmic language concerns his affinity for prime numbers, as each is indivisible by any number but one and the prime number. Messiaen mixed these prime units -- for example, having one instrument play a repetitive phrase in a group of five notes while another plays a different repetitive phrase of thirteen notes -- to make "metrical perception impossible, as there can be no common divisor between a unit of prime length and its subdivisible - or other prime - neighbors." 10

The end result of mixing these prime units is an ametrical rhythm, one in which a "pulse... [is] built from multiples of a basic unit; but this basic unit is generally faster (by a factor of two or three, say) than the succession of notes that we hear, whereas in most Western music the notes either move more or less with the pulse, or [are] at least clearly placed in relation to it." ${ }^{11}$ This particular type of rhythm contributes to the sense of timelessness in the Quatuor, as evidenced in its first movement, "Liturgie de cristal" (Crystal Liturgy). The fifteen-note melody of the cello recurs throughout the movement, while the piano plays a repetitive seventeen-note rhythm. ${ }^{12}$ The juxtaposition of both segments create what Messiaen refers to as a "rhythmic pedal," as the reiterations of fifteen and seventeen makes the possibility of reaching the point of resolution indeterminable; in fact, it is never realized. ${ }^{13}$ By postponing the point in which both

\footnotetext{
${ }^{9}$ Messiaen, trans. in Rischin, 131.

${ }^{10}$ Anthony Pople, "Messiaen's Musical Language: an Introduction," from The Messiaen Companion, ed. Peter Hill (Portland, OR: Amadeus Press, 1995): 36.

${ }^{11}$ Pople, "Messiaen's Musical Language: an Introduction," 35.

${ }_{12}^{12}$ Pople, Messiaen: Quatuor pour la fin du Temps, 25.

${ }^{13}$ Olivier Messiaen, The Technique of My Musical Language, trans. John Satterfield (Paris: Alphonse Leduc, 1966): 19.
} 
cycles were to end at exactly the same time, Messiaen is able to create "an elongation of time." 14 Another integral part of Messiaen's rhythmic style which helped create a sense of timelessness is the use of added values, in which a note or rest of shorter duration would be added to the length of an original note (see Ex. 2.1).

\section{Ex. 2.1: Added Values}

(a)

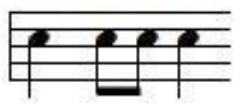

(b)

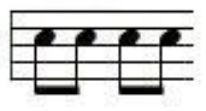

(c)

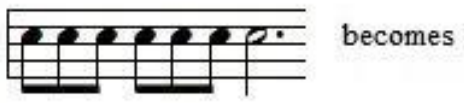

becomes

becomes
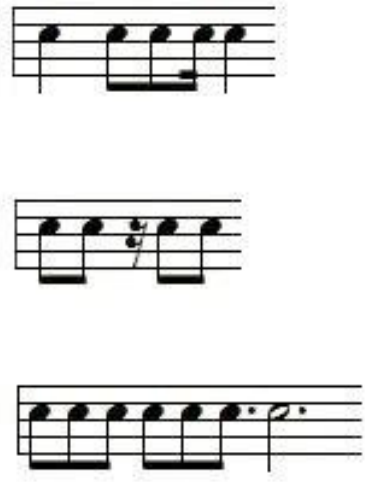

Often the original, simpler rhythm is not heard first, i.e., it is not treated as a theme that is then varied. By using these added values, Messiaen was able to introduce a method of "irregularizing regular patterns [whether by using] an extra note, ... an interpolated rest, ... or a lengthening of a single note within a pattern." ${ }^{15}$ The most-often cited example of this can be found in the principal theme of the Quatuor's sixth movement, “Danse de la fureur, pour les sept trompettes, " (Dance of Fury, for the Seven Trumpets), in which the rhythm would be in a conventional 4/4 time had the added value not been present (see Ex. 2.2).

\footnotetext{
${ }^{14}$ Matheson, 239.

${ }^{15}$ Pople, "Messiaen's Musical Language: an Introduction," 36.
} 
Ex. 2.2: "Danse de la fureur, pour les sept trompettes," principal theme

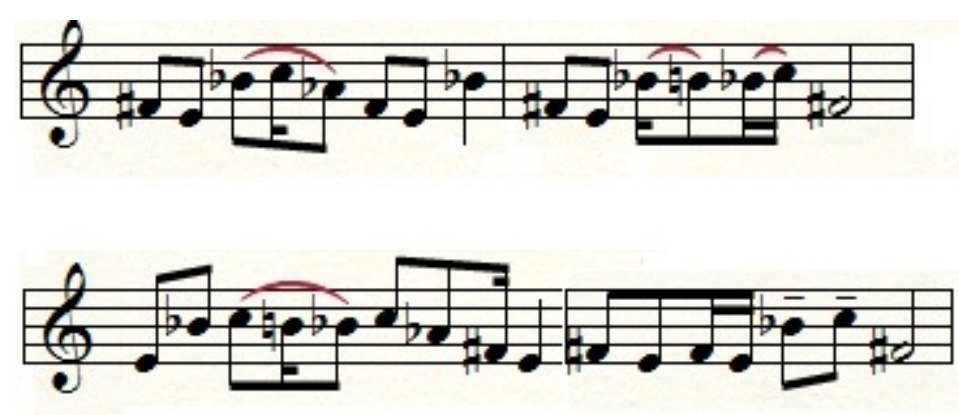

This irregular rhythmic pattern introduces an element of uncertainty, which allowed Messiaen to evoke the feeling of eternity: the listener would be expecting "the music to bowl along [in a predictable] phrase-by-phrase [manner; this] prevent[s] a regular eighth-note pulse from emerging [by utilizing added values, in which] isolated sixteenth-notes [are added throughout a phrase]." ${ }^{16}$ Not permitting a set pulse to become established in this movement does not "permit the listener to relax," as if to represent the expectation of the coming of eternity is at hand. ${ }^{17}$

To add to this unpredictability of rhythm, the composer used augmentation and diminution in select places to contribute to an unsteady pulse because of the position in the passage or their irregular usage, in which not all the values of a given rhythmic segment are increased or decreased. This is best exemplified in the combined use of expansion and contraction of a given rhythm found in the sixth movement of the Quatuor, in which the theme "is augmented and diminished variously -- its shape remaining constant" while the segment itself is lengthened or shortened (also shown in Ex 2.2). ${ }^{18}$

Although the use of augmentation and diminution has been used by a number of composers in Western art music, the employment of what Messiaen called nonretrogradable

\footnotetext{
${ }^{16}$ Pople, Messiaen: Quatuor pour la fin du Temps, 66.

${ }^{17}$ Pople, Messiaen: Quatuor pour la fin du Temps, 66.

${ }^{18}$ Pople, Messiaen: Quatuor pour la fin du Temps, 69.
} 
rhythm is indeed unique. This type of rhythm is one in which "the order of values [of a given passage is] the same [whether read forward or backward]. This feature exists in all rhythms that can be divided into two groups of retrograde related to each other by a central common value [see Ex. 2.3]."19

\section{Ex. 2.3: "Liturgie de cristal' - Cello Rhythm}

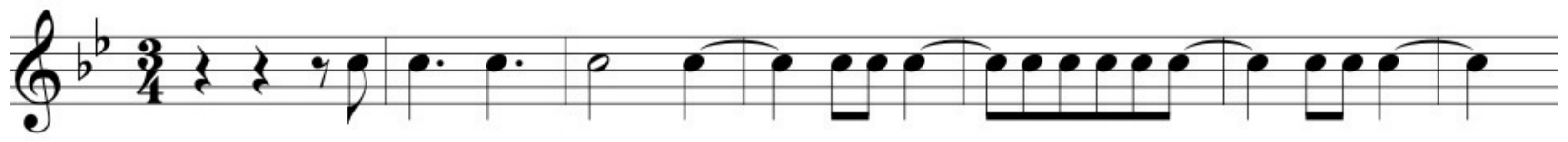

This technique was probably one of the more effective means by which Messiaen could demonstrate timelessness. Indeed, the composer referred to these specific rhythms as a major contributor to what he termed the "charm of impossibilities," in which his "music [is] able to express... the religious sentiments exalted by the theology and the truths of our Catholic faith."20 As these rhythms "cannot be used in retrograde because... one finds the same order of values again," ${ }^{21}$ the occurrence of this technique was exceptional and for Messiaen was symbolic as it was possible only through a connection with God.

To depict timelessness by using these special rhythms was the best way for the composer to capture humanity's striving to seek Eternity, as seen by Messiaen's extensive use of this device in the sixth movement, “Danse de la fureur, pour les sept trompettes,” where it dominates the center section (Ex. 2.4).

\footnotetext{
${ }^{19}$ Messiaen, trans. by Rischin, 132-3.

${ }^{20}$ Messiaen, Technique, trans. Satterfield, 8.

${ }^{21}$ Messiaen, Technique, trans. Satterfield, 8.
} 
Ex. 2.4: "Danse de la fureur, pour les sept trompettes," mm. 29-34

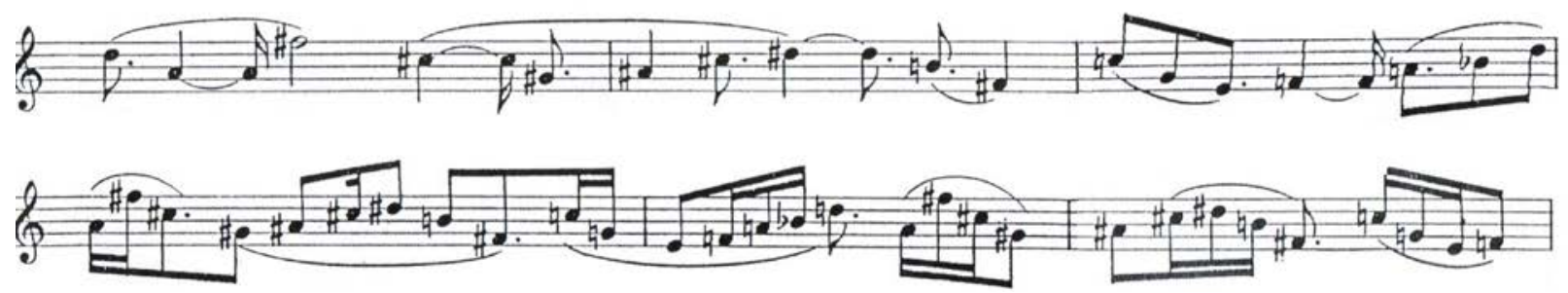

Here, seven sets of nonretrogradable rhythms are separated by barlines; the first five are indeed distinctive of each other, while the sixth is a replica of the fifth, and the final is a variant of both the fifth and sixth groups. ${ }^{22}$

As the importance of rhythm to depict time (or lack thereof) is crucial in the musical language developed and employed by Messiaen in the Quatuor, it must be noted that rhythm could not be excluded from other elements of his compositional process, as evidenced in the composer's use of birdsong.

\section{Birdsong}

In the composer's Technique de mon langage musical, Messiaen discussed extensively the significance of birds' songs. His affinity for this music of nature was deeply rooted in the fact that he viewed birds as "God's musicians... [as they were] intended to answer a need for spiritual purity and humility." ${ }^{23}$ Indeed, the important role birds have in Messiaen's compositions is best described in his prefatory notes to the third movement of the Quatuor, "Abîme des oiseaux" (Abyss of the Birds), in which he contrasts the mortal world (the abyss) with Heaven (the birds): "The abyss is Time, with its sorrows and its weariness. The birds are the opposite of Time; they are our desire for light, for stars, for rainbows and joyful songs!"24

In musical terms, Messiaen adds certain birdsong transcriptions to the score itself, such as

\footnotetext{
${ }^{22}$ Pople, Messiaen Quatuor pour la fin du Temps, 68.

${ }^{23}$ Pople, "Messiaen's Musical Language", 46-7

${ }^{24}$ Messiaen, trans. in Rischin, 130.
} 
in the first movement, "Liturgie de cristal" (Crystal Liturgy). The prefatory notes indicate that the songs of a blackbird or nightingale break the stillness of the early morning. ${ }^{25}$ Represented in the upper voices by the clarinet and violin, the instrumentation of the piece demonstrates the composer's treatment of the birds as heavenly, as they are played in the upper registers of both instruments. ${ }^{26}$ In another example of Messiaen's homage to birds, "Abîme des oiseaux" is an extensive transcription of birdsong scored for clarinet solo, though unlike the first movement, the program notes do not specify which particular bird. ${ }^{27}$

The importance birds have in depicting timelessness cannot be overemphasized. The composer stressed the possibility of hope and salvation by using birds as a symbol of freedom, as "in the literature and folklore of imprisonment, birds are seen as a symbol of freedom and hope." ${ }^{28}$ This is most evident in the Abîme, where Messiaen placed his version of a bird's song in a setting of nonretrogradable rhythms. In order to provide further emphasis of this concept, Messiaen segmented the movement into eight sections of asymmetrical "measure "lengths "measures" used loosely to give the performer a "psychological orientation" of where s/he is in the music than an actual division of musical time - that are defined by its changes of tempo:
A. Lent (eighth note $=$ c. 44$)$ : 13 measures to the last 'sans presser'
B. Presque vif (quarter note $=$ c. 126$)$ : 6 measures
C. Lent : 1 measure, sans presser
D. Presque vif: 4 measures
E. Modéré (eighth note $=$ c. 92): 5 measures
F. Lent : 12 measures
G. Modéré: 2 measures
H. Presque vif: 1 measure to the last four notes 'Lent (sixteenth note $=$ c. 100$).{ }^{29}$

\footnotetext{
${ }^{25}$ Messiaen, trans. in Rischin, 129.

${ }^{26}$ Pople, Messiaen, Quatuor pour la fin du Temps, 20.

${ }^{27}$ Matheson, 240.

${ }^{28}$ Pople, Messiaen, Quatuor pour la fin du Temps 41.

${ }^{29}$ Pople, Messiaen, 41.
} 
As can be seen in the above outline, the phrases of each section are unevenly divided. Setting birdsong in this fashion helps support Messiaen's assertion that "the birds are the opposite of Time." ${ }^{30}$ It is quite obvious that Messiaen's affinity for birdsong played an important part of making his musical language truly unique. However, what fundamentally distinguishes his compositional technique from other twentieth century composer's is his attempt to capture visual color in his pieces.

\section{Color}

The passage from the Book of Revelations Messiaen chose for the Quatuor in itself supports the composer's fondness for color, about which he later wrote in his Traité de rythme, de couleur, et d' ornithologie (Treatise of Rhythm, Color, and Birdsong), "During my captivity, it was colored dreams that gave birth to the chords and rhythms of my Quatuor pour la fin du temps." ${ }^{31}$ This possibly stems from his ability to see corresponding colors when listening to music, a phenomena known as synesthesia. The brilliance and specificity of color he experienced influenced the types of sounds he would capture in his compositions, as he was "convinced that one [could] convey this to the listening public."32

The composer's perception of color through sound was rooted harmonically. ${ }^{33}$ However, pinpointing a correlation between a specific chord and/or mode to an exact color can yield a mixture of results. In his article in The Messiaen Companion, musicologist Jonathan W. Bernard discovered in his investigation of Messiaen's modes and the colors that the composer saw "[did] not...always yield a perfect and unequivocal match between a particular color and a particular

\footnotetext{
${ }^{30}$ Messiaen, trans. by Rischin, 130.

${ }^{31}$ Olivier Messiaen, Traité de rythme, de couleur, et d' ornithologie, trans. in Pople, Messiaen Quatuor pour la fin du Temps 34.

32 Olivier Messiaen, in Almut Rössler, Contributions to the Spiritual World of Olivier Messiaen, trans. Barbara Dagg and Nancy Poland (Duisburg, Germany: Gilles und Francke, 1986): 122.

33 Jonathan W. Bernard, "Colour," from The Messiaen Companion, ed. Peter Hill (Portland, OR: Amadeus Pres, 1995): 205 .
} 
modal transposition... [as]other factors operate to influence these color perceptions." ${ }^{34}$ For example, Messiaen would sometimes claim to associate blue-orange, other times with blue or blue-green, with the third transposition of mode three (see Ex. 2.5). ${ }^{35}$

Ex. 2.5: Third Mode of Modes of Limited Transposition and Its Third Transposition

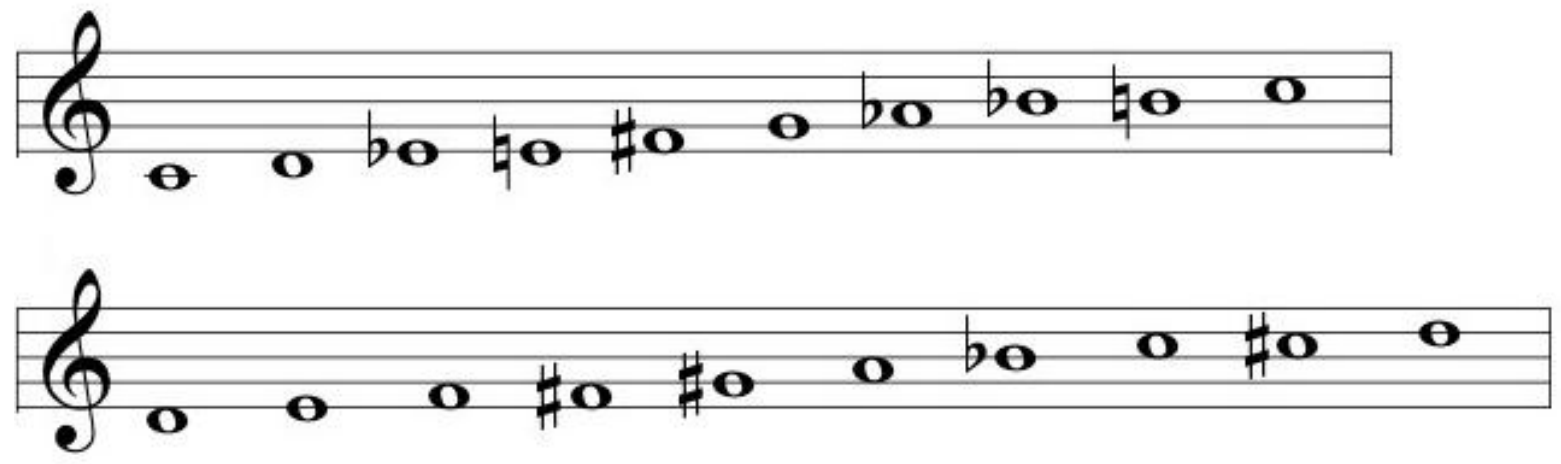

This can be seen in his own description of the second movement of the quartet, the "Vocalise, pour l'Ange qui annonce la fin du Temps," ("Vocalise for the Angel that Announces the End of Time"), in which Messiaen described the first part of the second section as "gentle cascades of blue-orange chords...[a] distant carillon." 36 To explain the genesis of the different colors that Messiaen would see requires an explanation of a crucial part of his musical language, his theory of the modes of limited transposition. He described these modes as a component of the "charm of possibilities," as they "cannot be transposed beyond a certain number of transpositions, because one always falls again into the same notes." ${ }^{37}$ For example, the whole-tone scale, which Messiaen named as the first mode, is only transposable twice.

When it came to different colors that the composer envisioned, Messiaen told interviewer

\footnotetext{
${ }^{34}$ Bernard, 209-10. The evidence of the composer's synesthesia is well-documented in the prefatory notes of many of his pieces, including the Quatuor, as well as in interviews and the musical scores themselves.

${ }^{35}$ Bernard, 207.

${ }^{36}$ Messiaen, trans. in Rischin, 130.

${ }^{37}$ Messiaen, Technique, trans. Satterfield, 8.
} 
Claude Samuel, "The modes have overall colors corresponding to their various positions." 38 Available evidence from the prefatory notes of the Quatuor and other compositions as well as interviews with the composer reveal that he associated certain specific colors to specific modes; the individual transpositions of certain modes would yield different combinations of colors. However, Bernard has concluded that "a perfect and unequivocal match between a particular color and a particular modal transposition" could not always be ascertained. ${ }^{39}$ Other factors apparently caused a brilliant effect of many colors that would simultaneously create an effervescent aura, as that which is found in "a rainbow or a stained-glass window." ${ }^{40}$ These elements include the chord on the dominant (see Ex. 2.6), which is derived from the dominant seventh chord of the major scale, and, according to Messiaen, "contains all the notes of the major scale." 41

\section{Ex. 2.6: Chord on the Dominant}

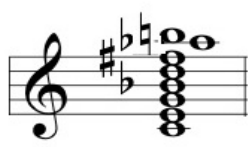

Another element used to create the colorful aura is his so-called chord of resonance, derived from mode three of the Modes of Limited Transposition (as shown above in Ex. 2.5), from which Messiaen liberally borrowed. Also important in producing the synesthetic response is the chord of resonance, (as seen in Ex. 2.7) whose sonority is "effects of pure fantasy, similar by a very distant analogy to the phenomenon of natural resonance." ${ }^{42}$

\footnotetext{
${ }^{38}$ Olivier Messiaen, Olivier Messiaen: Music and Color - Conversations with Claude Samuel, trans. E. Thomas E. Glasgow (Portland, OR: Amadeus Press, 1994): 64.

${ }^{39}$ Bernard, 209.

${ }^{40}$ Bernard, 211.

${ }^{41}$ Messiaen, Technique, trans. Satterfield, 69.

${ }^{42}$ Messiaen, Technique, trans. Satterfield, 71.
} 


\section{Ex. 2.7: Chord of Resonance}

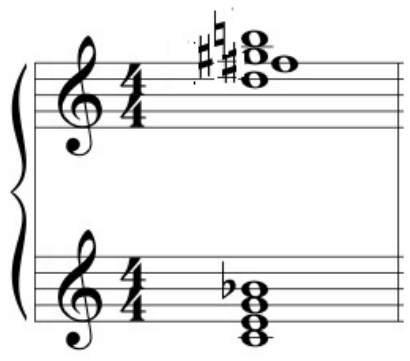

Although it is difficult to specifiy the particular colors attributed to exact harmonies or modes, color plays a major role in the Quatuor, so much so that the composer felt it necessary to introduce the "blue-orange chords" $" 43$ in the second movement and recall them again in the seventh movement, Fouillis d'arcs-en-ciel, pour l'Ange qui annonce la fin du temps (Tangle of Rainbows, for the Angel Who Announces the End of Time). The images Messiaen sought to capture apparently were significant enough that he felt it necessary to "[deviate] from [his] normal unflappable equilibrium in dealing with theological events of apocalyptic proportions." 44

\section{Other Considerations}

The importance of time, birdsong, and color cannot be overstated when analyzing the effectiveness of conveying the Quatuor's message inspired by the Book of Revelations. However, what truly makes Messiaen's expression successful is not the use of these factors alone; indeed, juxtaposing and combining these elements together have allowed the composer to provide contrast between the mortal world and eternity.

This accumulation of materials to emphasize a certain image can best be seen in the seventh movement. The composer reprises many of the components of the second movement in

\footnotetext{
${ }^{43}$ Messiaen, trans. in Rischin, 130.

${ }^{44}$ Pople, 78.
} 
order to bring forth the "tumult of rainbows" 45 to which he alluded in the program notes. The cello plays the first theme, which recalls the theme from the second movement's central section that uses an added value (see Ex. 2.8a). ${ }^{46}$

Example 2.8a: Combined Compositional Elements in "Fouillis d'arcs-en-ciel, pour l'Ange qui annonce la fin du temps", Cello Theme with Piano Accompaniment

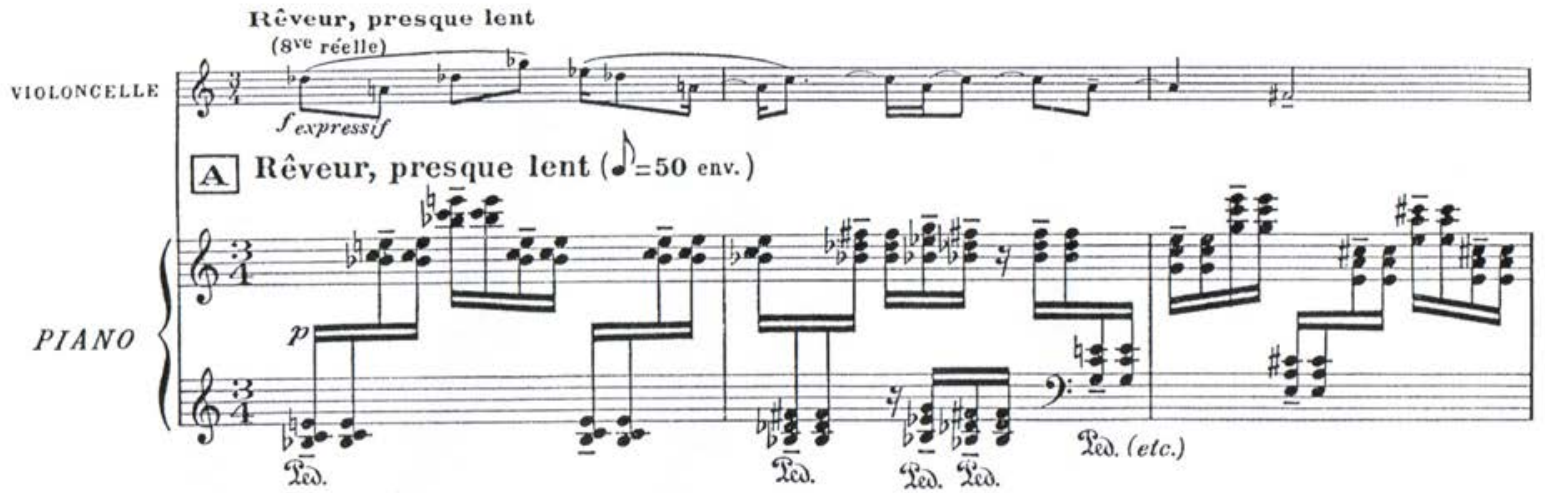

It is accompanied by the piano, which plays chords in perpetual motion, derived from the chord on the dominant. ${ }^{47}$ As the music develops, the clarinet takes over, playing an arpeggiated passage derived from the chord on the dominant, which flows "in one direction then another, in the palindromic manner of a non-retrogradable rhythm [see Ex. 2.8b]",48

\footnotetext{
${ }^{45}$ Messiaen, trans. in Rischin, 130.

${ }^{46}$ Pople, 72-3.

${ }^{47}$ Pople, 78.

${ }^{48}$ Pople, 79.
} 
Example 2.8b: Combined Compositional Elements in "Fouillis d'arcs-en-ciel, pour l'Ange qui annonce la fin du temps", Clarinet Passage with Arpeggiated Chord on the Dominant
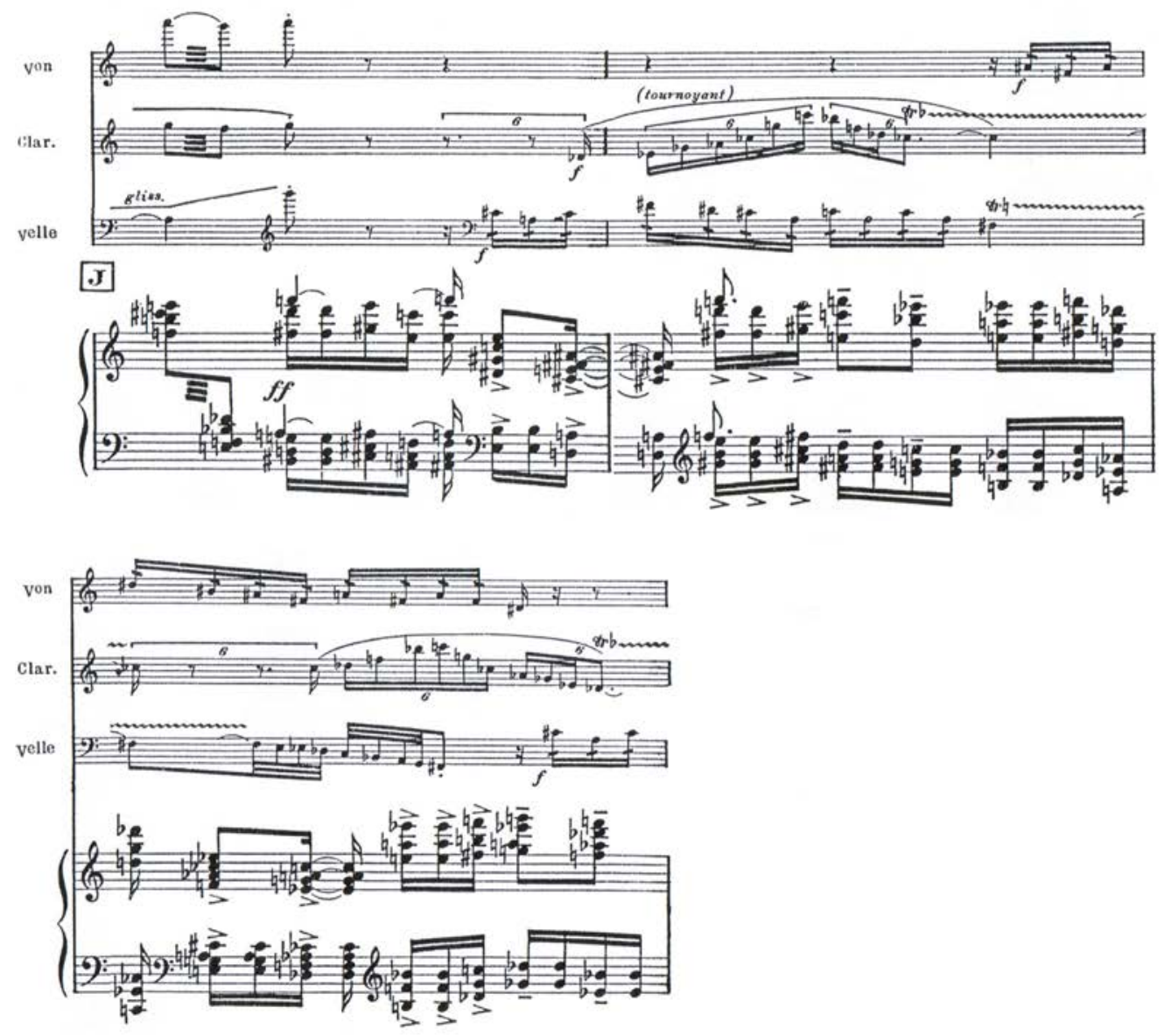

Another example of the composer combining elements from his musical language to evoke his idea of Heaven is demonstrated in the first movement of the Quatuor, Liturgie de cristal (Crystal Liturgy). Here Messiaen scored the violin and clarinet in their upper registers, to represent a blackbird's or nightingale's song, which he regarded as heavenly. In the meantime, as mentioned previously, the piano and cello provide a background of sound set in isorhythms. ${ }^{49}$ Combining these two elements allowed Messiaen to create a setting that to him best portrays Heaven; the violin and clarinet act as God's musicians as they play birdsong, while the cello and piano represent Eternity, as their melodic lines never terminate at the same time.

\footnotetext{
${ }^{49}$ Pople, 17.
} 
While combining two elements of his rhythmic language to create a setting was extremely effective, it can be argued that juxtaposing these techniques to contrast each other may have been Messiaen's tour de force. To support this statement, one needs only to look at the settings of the entire Quatuor, as there is evidence that the composer could not have showed the triumph of Heaven without showing the shortcomings of humanity. The first three movements of the Quatuor are a deliberate attempt to show the salvation of Heaven, which is then purposely contrasted with the fourth movement, the "Interméde." To heighten the contrast between heaven and Earth, Messiaen purposely turned away from his elaborate rhythmic language and instead “develop[ed] a very traditional rhythmic pattern for violin, clarinet [,] and cello in unison." ${ }^{.50} \mathrm{By}$ including the "Interméde" as the middle movement of the Quatuor, Messiaen not only brought to light the contrast between eternity and mortality of mankind: he also was able to lessen the accumulated tension, which are more grandiose in subject matter (movements five and eight are both settings of adoration of Christ, while movements six and seven deal with the catastrophes and aftermath of the Apocalypse).

\section{Conclusion}

The far-reaching effects that came from the composition of the Quatuor cannot be overemphasized. While it is true that by writing the piece the composer was able to find solace in the deplorable onditions of his captivity (and likewise, provide his fellow prisoners with a break from the drudgery of their imprisonment), the Quatuor had a significant impact on both Messiaen's future compositions and all of Western art music.

Most importantly, developing and perfecting the musical language used in the Quatuor allowed the composer an avenue to express his deeply rooted (yet complicated) faith in God. By breaking away from established conventions used in Western art music, Messiaen was able to

\footnotetext{
${ }^{50}$ Matheson, 241.
} 
portray beliefs that were not necessarily universally held by Catholics during this era, allowing him to focus on a "theology of glory" rather than the despair that was easily ascertained by the passage he chose from Revelations.

Later captured in his treatise Technique de mon langage musical, Messiaen's compositional techniques would become uniquely identifiable with him and would attract a group of disciples that included Pierre Boulez. The meticulous degree in which Messiaen had regulated his rhythmic and tonal considerations would later lead to Boulez's own attempts to control other aspects of music and eventually evolve into total serialization. Equally important as the treatment of rhythm and harmony is the inclusion of birdsong in Messiaen's work. The Quatuor was one of his earliest works that featured this music as an important characteristic that would become more prevalent in his later compositions. 


\section{Chapter 3}

\section{Visions de l'Amen: Messiaen's Interpretations of Amen}

The compositional process involved in creating Quatuor pour la fin du Temps provides an excellent example of Olivier Messiaen's attempts to interpret a specific Biblical passage, in that instance tailoring it to his own belief in the hope that comes at the end of the Apocalypse, when time ceases to exist. The composer's major work for two pianos written after the Quatuor, Visions de l'Amen (1943), is an extension of his wish to spread his theology of glory; however, rather than interpreting a single scriptural passage, he instead turned to the theological musings of two religious writers, Columba Marmion (1858-1923) and Ernest Hello (1828-1885).

Marmion's influence on Messiaen was indeed critical during this period, perhaps more so on the composer's Vingt Regards de l'Enfant Jesus (to be discussed in Chapter 4 of this document) than on the Visions. However, as minor an impact as this may have, it is still important to understand Marmion's reflection on the Crucifixion, since not only did his philosophy oppose Catholic doctrine, but at the time was willingly embraced by Messiaen himself. One of the central tenets of faith, the Crucifixion is based on the belief that the sins of the world are taken up by Jesus, and therefore His death serves as penance for them. However, rather than looking at Jesus as one who assumes the sins of the world, Marmion takes a different stance: the Crucifixion is necessary because "God curses His Son as one who 'represents' the [wrongs of humankind... as] 'the heavenly Father wanted to break him in his suffering[,]...to crush him."'1

In conjunction with Marmion's religious philosophy on Christ's death, Messiaen also avidly read the more conventional works of Ernest Hello, whose 1877 book Paroles de Dieu

\footnotetext{
${ }^{1}$ Siglind Bruhn, Messiaen's Contemplations of Covenant and Incarnation: Musical Symbols of Faith in the Two great Piano Cycles of the 1940s. From Dimension and Diversity: Studies in 20th Century Music, No. 7, Mark De Voto, ed. (Hillsdale, NY: Pendragon Press, 2007): 79.
} 
(Words of God) is comprised of reflections upon different passages from both Old and New Testaments and traces the lives of some of the Biblical heroines who preceded the Virgin Mary. Most pertinent to Visions is the fact the book goes into an extensive reflection on the word “Amen". ${ }^{2}$ In Part V, Hello described different aspects of the word, discussing seven different characteristics within the definition. Summarily, the author explores the linguistic and grammatical functions of Amen, but stresses the overall power of the word.

Hello described the grammatical usage of Amen, first discussing the structural function of the word itself, then moving on to finding synonyms of the term. He thereby pointed out the flexibility of the term, as it can be used as a name, (as in Revelation 3:14, "And unto the angel of the church of the Laodiceans write; These things saith the Amen, the faithful and true witness, the beginning of the creation of God"3 ), affirmation of a statement, ("in truth, I tell you"), or reinforcement of a wish (i.e., "so be it."). ${ }^{4}$ His explanation of Amen's usage mostly emphasizes the significance of the word, as it is used to "open up surprising new dimensions, ... [such] as light that separates darkness ... [or to be a] word as deed or act, [such as] 'the act that opens and closes time,' [and also] 'the word of Genesis, which is the beginning... and the word of the Apocalypse, which is the genesis of consummation. "“5

By describing the function of the word, Hello then addressed the power of its meaning, as it can be self-sufficient in prayer, whether used as a wish or contemplation. The strength of this word is that it confers a certain power upon humanity, as it allows one to acknowledge dependence upon God for triumph and glory. ${ }^{6}$ By recognizing humankind's ability to use Amen as a means to taking a pathway to heaven, Hello finally concluded this discourse by explaining

\footnotetext{
${ }^{2}$ Bruhn, 73.

${ }^{3}$ Rev. 3:14 (King James Version).

${ }^{4}$ Bruhn, 74-5.

${ }^{5}$ Bruhn, 75.

${ }^{6}$ Bruhn, 76 .
} 
that other beings who "represent other levels of the universe, [such as] the 'voices' of stars and planets, the voices of angels, and ... those whom Messiaen calls 'symbolic persons' [such as the saints, do join in] pronouncing the Amen of peace and the Amen of joy."”

From this lengthy discussion as well as Marmion's own thoughts, Messiaen was able to derive a foundation upon which he would compose Visions: "expressions of the creative act, of obedient acceptance, of spiritual desire[,] and of eternal consummation." ${ }^{8}$ Evidence is clearly laid out in the prefatory notes to the piece:

"Amen" has four different meanings:

1. Amen, so be it! The act of creation.

2. Amen, I subject myself to you, I accept. Thy will be done!

3. Amen, the desire, the yearning that everything may happen; that you may dedicate yourself to me as I dedicate myself to you. 4. Amen, it is so. Everything is predestined in all eternity and will be fulfilled in paradise. In that I have accepted the life of beings who say "Amen" simply through their existence, I wanted to express the entire richness of Amen in seven musical visions.

\section{Amen of Creation}

And God said, Let there be light! And there was light. Over a double glockenspiel ostinato in the first piano, the second piano intones the subject of creation: the main theme of the work. The entire composition is a crescendo, beginning from an absolute pianissimo of that original fog in which the power of light is already contained. All bells quiver in this light - as well as in life.

II. Amen of the stars and the planet with the ring Brutal and wild dance of the planets. The stars, sun and Saturn spin in unrestrained frenzy. God calls and they answer: Amen, here we are! All of the different movements reflect the life of the planets and the wonderful rainbow that enables Saturn's rings to shine.

III. Amen of Jesus' agony

Jesus suffers and cries. My father, if it be possible, let this cup pass away from me; nevertheless not my will, but thy will be done. He accepts his fate - so be it, Amen. Three musical ideas: first, the curse of the Father concerning the sins of the world, second, a scream, third, a heartrending cry. Christ's suffering brings man

\footnotetext{
${ }^{7}$ Bruhn, 76.

${ }^{8}$ Paul Griffiths, Olivier Messiaen and the Music of Time (Ithaca, NY: Cornell University Press, 1985): 109.
} 
forgiveness and renewal. Unspeakable suffering, of which blood and sweat give only a faint intimation.

IV. Amen of yearning

The word "yearning" must be understood here in its highest spiritual meaning. There are two themes that refer to longing. The first is slow and characterized by deep tenderness: the peaceful fragrance of paradise. The second is much more tumultuous: the soul is filled with a terrible love that increases until it breaks into ecstasy. The two main voices seem to melt together in the coda, and nothing remains but the harmonious stillness of heaven.

$\mathrm{V}$. Amen of the angels, the saints, the song of birds Song of the immaculacy of the saints: Amen. The jubilant vocalises of the birds: Amen. The angels fell before the throne: Amen. At first, the songs of the angels and saints: completely concentrated on the essence, and very pure. Then, a middle section based on the songs of the birds, in which a brilliant piano passage can unfold. Then, a changed recapitulation of the song of the angels and saints, with a nonreversible rhythmic canon at three levels.

VI. Amen of Judgment Day

Three icy tones, like the bells of clarity. Truly I say unto you: Amen. Depart from me, ye cursed! A deliberately short and brusque piece.

VII. Amen of fulfillment

The life of the transfigured bodies in a glockenspiel of light, from clarity to clarity, Amen. The entire rainbow of the gems of the apocalypse that ring, collide, dance and submerge the light of life in their fragrance. ${ }^{9}$

As can be seen in the notes, the parallels between his intentions and Hello's work can be easily discerned. Additional evidence of the most obvious of the parallels between the theologian's literary work and the composer's musical score is found in the seven movements of the cycle itself, as each section takes on a different meaning as expounded in Hello's book. In the first movement of the piece, "Amen de la Création," Messiaen attempts to portray a verse from the Book of Genesis that in turn captures the essence of one of Hello's "mystical definitions of

\footnotetext{
${ }^{9}$ Messiaen, Olivier Visions de l'Amen, trans. in Messiaen, Olivier, Works for Piano Duo -- Messiaen: Visions de l'Amen; Beethoven Grosse Fuge, performed by DuoD'Accord. Oehms Classics B0021JLQVK, 2008. CD.
} 
'Amen' [that] includes 'the light that separates darkness'.,"10

The second definition of "Amen" that Messiaen opts to include as an integral part of the Visions is Christ's acceptance of fate. Rather than drawing closely from Hello's text, however, the third movement of Visions (“Amen de l'agonie de Jesus") departs from Catholic doctrine, choosing to represent Marmion's philosophy of the Crucifixion. As explained in the prefatory notes, Messiaen portrays Jesus' understanding that He is to be put to death, although He would prefer that "this cup pass away from me." ${ }^{11}$ This contradicts the Catholic tradition, in which it is thought that Christ wholly accepted his fate to be put to death in order to save humanity. ${ }^{12}$

While in the second definition of Amen the composer introduced the only deviation from Hello's book, he returns to the main idea of Paroles de Dieu in the third meaning. Describing Amen as a vehicle for humans "in discussing their plea to God...aim... at securing God's favors... [and] defining the future actions of the implorers themselves." 13 The word, then, is a promise to God that may be thought of as saying "'May you give yourself to me and I, to you!'... a true covenant between Creator and creature." ${ }^{\prime 14}$ This definition corresponds with the piece's fourth movement, "Amen du Désir," in which Messiaen intended to express the "metaphysical meaning ... [i.e.], the human desire for union with God.",15

To continue in the manner in which to communicate the desire for oneness with God, Messiaen moved to the meaning of Amen as humanity uniting with the divine, or striving for a "sense of fulfillment," with the Father, as he attempted to portray in the final movement, "Amen

\footnotetext{
${ }^{10}$ Bruhn, 76.

${ }^{11}$ Messiaen, Olivier Visions de l'Amen, trans. in Messiaen, Olivier, Works for Piano Duo -- Messiaen: Visions de l'Amen; Beethoven Grosse Fuge.

12 Bruhn, 79.

${ }^{13}$ Bruhn, 77.

${ }^{14}$ Bruhn, 77.

${ }^{15}$ Bruhn, 77.
} 
de la Consommation." ${ }^{16}$ Although the composer aligns himself with Hello's beliefs that Amen is "an act that opens and closes time, ${ }^{, 17}$ Messiaen chooses to extend the meaning of the word to assert that Amen means "everything is set forever" rather than giving the word only two distinct points in time ${ }^{18}$

The above meanings of Amen clearly point to either humans or God around which the term revolves; however, the final meaning Messiaen attempts to convey is more universal, as the word is spoken by others, as exemplified in the second and fifth movements ("Amen des stoiles, de la planete a l'anneau" and "Amen des anges, des saints, du chant des oiseaux"). Messiaen captures Hello's concept of Part V of the Paroles by having voices “of different levels of the universe... pronouncing the Amen of peace and the Amen of joy." 19

Though the above pronouncement of "Amen" by the celestial bodies, the saints, and the birds connects to the notion that there is a universality implied in the word "Amen," in this declaration of the word Messiaen hoped to capture "the expression of condemnation... [as in] 'Depart from me, you who are cursed," [i.e.,] God's final judgment of human life and conduct. ${ }^{20}$ This is best exemplified in the sixth movement of the Visions, "Amen du Jugement," in which the composer unambiguously "reveals the eschatlogical dimension of Christian faith in God's final judgment of human life and conduct."11

By including the prefatory notes in the Visions, Messiaen was able to make a more obvious connection to Hello's Paroles de Dieu, and, to lesser extent, Marmion's philosophy. In a more indirect manner, the composer also paid homage to the philosophers in the score itself. The

\footnotetext{
${ }^{16}$ Bruhn, 77.

${ }^{17}$ Bruhn, 75.

${ }^{18}$ Bruhn, 77.

${ }^{19}$ Bruhn, 76.

${ }^{20}$ Bruhn, 78.

${ }^{21}$ Bruhn, 78.
} 
same musical devices of rhythm, birdsong, and color the composer used in Quatuor pour la fin $d u$ Temps can be found in this piece as well. Just as importantly, as the individual instruments in the Quatuor play a part in helping Messiaen portray his religious ideas, so too the two pianos in Visions work in a heterophonic manner to convey the composer's religious message. Messiaen noted in the preface to the score that each piano part is different in character, as the first piano is given "the rhythmic difficulties, the bunches of chords, everything concerned with speed, allure, and quality of sound," while the second piano is given "the principal melody, the thematic elements, everything demanding emotion and power."22 Although the two parts are very different, the "division of labor... suits the heterophonies of entirely different musical styles and speeds." 23

However, unlike the quartet, the cyclical features are more prevalent in this piece, as "the use of cyclic themes does not form the [entire] symphonic basis of all thematic material in the work... [Rather, it] symbolizes the 'Amen' of the divine will. ${ }^{24}$

\section{The Theme of Creation and the Accompanying Carillons}

The Theme of Creation is named in the prefatory notes to the piece as well as labeled explicitly in the score. The theme is always accompanied by what Messiaen terms as "carillons," two parts of accompanying chordal passages, which also play an important role in the composer's attempts to symbolize the meaning of Amen. The theme and the carillons turn up several times throughout the piece, in movement one, "Amen de la Création," movement three, “Amen de l'agonie de Jésus," movement four, “Amen des anges des saints, du chant des oiseaux," and movement seven, "Amen de la Consommation." Their appearance takes on different meanings, but "Messiaen establishes a connection between the two pianos and their

\footnotetext{
${ }^{22}$ Messiaen, Visions de l'Amen, trans. in Griffiths, Messiaen and the Music of Time, 108.

${ }^{23}$ Griffiths, 108.

${ }^{24}$ Robert Sherlaw Johnson, Messiaen (Berkely, CA: University of California Press, 1975): 64.
} 
respective materials by choosing a similar horizontal structure for the theme and the accompanying carillon [using] a pattern that [is either] identical, varied, or extended" from the theme's original presentation. ${ }^{25}$

The theme itself (Ex. 3.1) is characterized by "a modal basis, a closed harmonic progression, a strictly metric organization, and a...melody" consisting of four regular phrases. ${ }^{26}$ The texture in which this theme is presented is homophonic, comprised of seven different chords based on the Mixolydian scale on A. As a whole, the phrase "gives the impression of an almost classical cadence": the chord progression is tonic-subdominant-subdominant minor-tonic. ${ }^{27}$ This strong sense of tonality, combined with the simplicity of the theme's harmonic progression, rhythm, and phrasing is a means for the composer to emulate light, which, in his commentary, is the most important of God's creation. ${ }^{28}$

\section{Ex. 3.1: Theme of Creation}
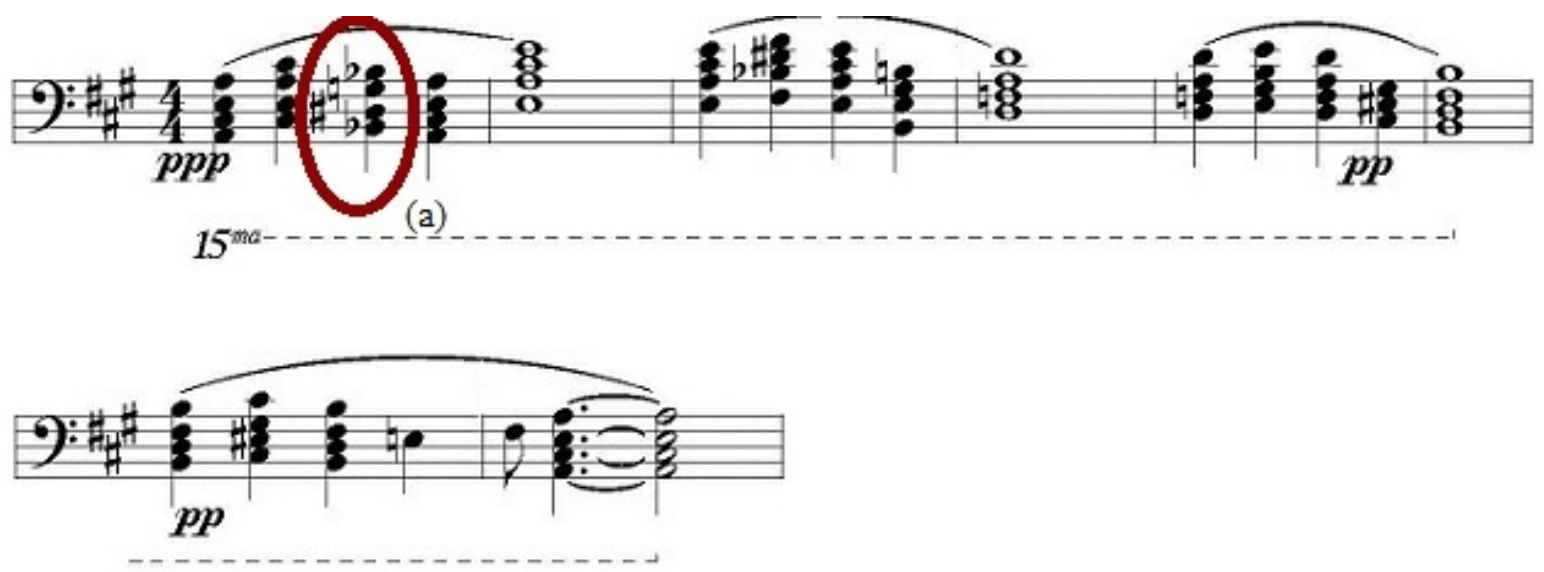

The most interesting chord of this entire theme is one built on the seventh degree of the Mixolydian scale, G, labeled as (a) in Ex. 3.1. The chord, spelled G-B flat-D sharp, can be

\footnotetext{
${ }^{25}$ Bruhn, 81.

${ }^{26}$ Bruhn, 81.

${ }^{27}$ Bruhn, 81-2.

${ }^{28}$ Bruhn, 85.
} 
thought of as a minor triad with augmented fifth, but actually is heard in this context as G-B flatE flat, the first inversion of an E-flat major chord. ${ }^{29}$ The ambiguity of this chord can be attributed to the fact that Messiaen chose to avoid the natural tendency of the leading tone to resolve to tonic, which musicologist Siglind Bruhn ascribed to "linking the beginning of [the] world's development with its teleological goal -- in the divine perspective, not in the perspective of ambitious humans."30

The carillons that appear with the theme can be found in Piano I, as both right and left hands each play a separate line of chords (Ex. 3.2). These parts consist of simultaneously played "short and simple, infinitely repeated group of three chords subjected to a rhythmic ostinato, [in which both lines are placed in a setting] that encompasses [separate] palindromes." ${ }^{31}$ The palindromes consist of "three durations, the second of which is half as long as either value which surrounds it." ${ }^{32}$ These two lines use non-retrogradable rhythms and are independent of each other, as Messiaen intended to evoke a sense of timelessness. ${ }^{33}$ Indeed, if both carillon sequences and the theme were to continue to play their given patterns ad infinitum, it would take "more than three hours" to come back to their initial starting point. ${ }^{34}$

\footnotetext{
${ }^{29}$ Bruhn, 82 .

${ }^{30}$ Bruhn, 82.

${ }^{31}$ Bruhn, 82.

${ }^{32}$ Bruhn, 83.

${ }^{33}$ Bruhn, 82-4.

${ }^{34}$ Bruhn, 84.
} 


\section{Ex. 3.2: Carillons I and II from "Amen de la Création"}

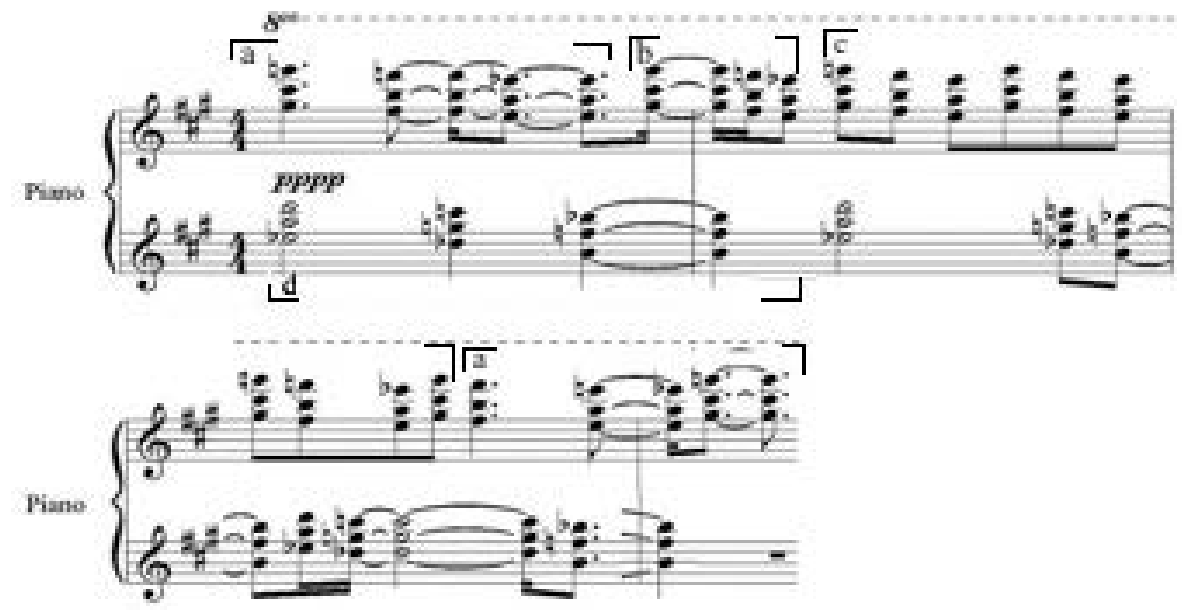

\section{Thematic Development}

Messiaen subjects both the Theme of Creation and its accompanying carillons to similar treatment in order to develop them throughout the piece. These two elements are developed in various ways in the several movements in which they appear. In the first, the theme itself is played "three times in stanzaic manner before it is complemented by a coda." 35 The contour of the melodic line rises and falls, with the intervallic distance between the penultimate and final chord gradually decreasing in each subsequent segment. ${ }^{36}$ The next two appearances of the theme, the next two appearances occur in immediate succession, are then subjected to octave displacement and an increase in dynamic level from pianississimo to più forte. ${ }^{37}$ The final statement added on to the end of the movement features rising chords in the bass set as rapid-fire grace notes, and the movement "does not end but is... abruptly cut off.",38

While the theme in "Amen de la Création" is subjected to these treatments, the uppermost

\footnotetext{
${ }^{35}$ Bruhn, 84.

${ }^{36}$ Bruhn, 87.

${ }^{37}$ Griffiths, 109.

${ }^{38}$ Griffiths, 109.
} 
carillon, represented as "a", "b", and "c" in Ex. 3.2, also presents three consecutive times the rhythm as 6-3-6, 2-1-2, 8-4-8, (based on an sixteenth-note pulse) before an extension is added. The lower carillon (labeled "d" in Ex. 3.2), however, played in the left hand of Piano I, varies from both its upper counterpart and the theme, as its sixteenth-note based rhythm (8-4-8, 10-510) is only repeated twice before Messiaen adds "a related but non-symmetrical expansion." 39

While the exposition of the Creation theme and its accompanying carillons takes place in the first movement of the cycle, the three components are revisited again in movements three, four, five, and seven, undergoing different transformations to symbolize the different definitions of Amen. In the third movement, Messiaen uses the theme and the accompanying ostinatos as part of the coda. ${ }^{40}$ This brief statement of these elements is quite different than their previous appearance in the movement, although Messiaen does make an allusion to the Creation theme's rhythm (see Ex. 3.3), which is a diminished form of the theme's final phrase. To recall the theme in this setting not only helps tie the movement to the rest of the cycle, but also allows the composer to draw a connection between Jesus's death for humankind's sins, the creation of a newly cleansed world.

Ex. 3.3: Thematic Development of the Theme of Creation in "Amen de l'agonie de Jésus"

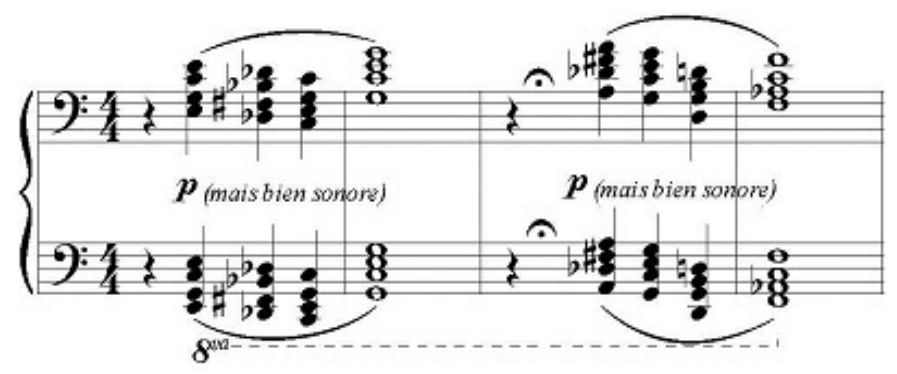

\footnotetext{
${ }^{39}$ Bruhn, 84 .

${ }^{40}$ Griffiths, 109.
} 
Although "Amen de l'agonie de Jésus" briefly returns to a variant of the Theme of Creation, the following movement, "Amen du Desir," contains only the theme's cadential formula. Rather, Messiaen uses only the theme's cadential formula (I-V-iv-ii-I) and a diminished form of its rhythm (four eighth-notes followed by a quarter rather than the four quarters followed by a half note). ${ }^{41}$ Also, the composer uses Piano I to play the non-retrogradable rhythms found in the prior appearances of the carillons, beginning in section $\mathrm{B}$, the first occurrence in the movement where Piano II takes a brief respite (see Ex. 3.4). By relying on such an indirect referral to the cyclic components of the piece, Messiaen addresses humanity yearning for God's love and unification in heaven: the soul attempts to find its way to righteousness, but in its path are the trials that block its way. ${ }^{42}$

\section{Ex. 3.4: Nonretrogradable Rhythms in "Amen du Desir"}

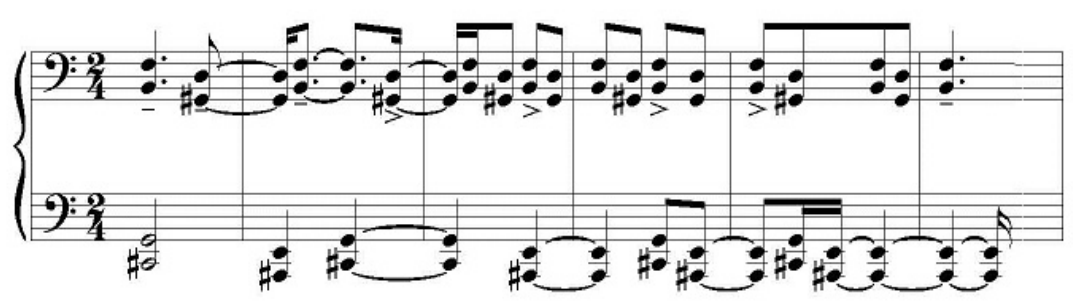

The brief appearance of the Creation theme and its carillons in the fourth movement gives way to more substantial thematic development in the next movement, "Amen des anges, des saints, du chant des oiseaux." Here, the composer "quotes an [expansion] of the Creation theme," in which Piano II splits the four-part texture between the two hands and restates the first phrase with a few added grace-note flourishes. The quotation is then immediately followed by a variation on the theme in which the texture becomes thicker, as rhythmic palindrome is

\footnotetext{
${ }^{41}$ Griffiths, 110.

${ }^{42}$ Bruhn, 123.
} 
introduced, 2-2-3-5-3-2-2 (see Ex. 3.5). ${ }^{43}$

Ex. 3.5: Recurrence of Creation Theme in "Amen des anges, des saints, du chant des oiseaux"

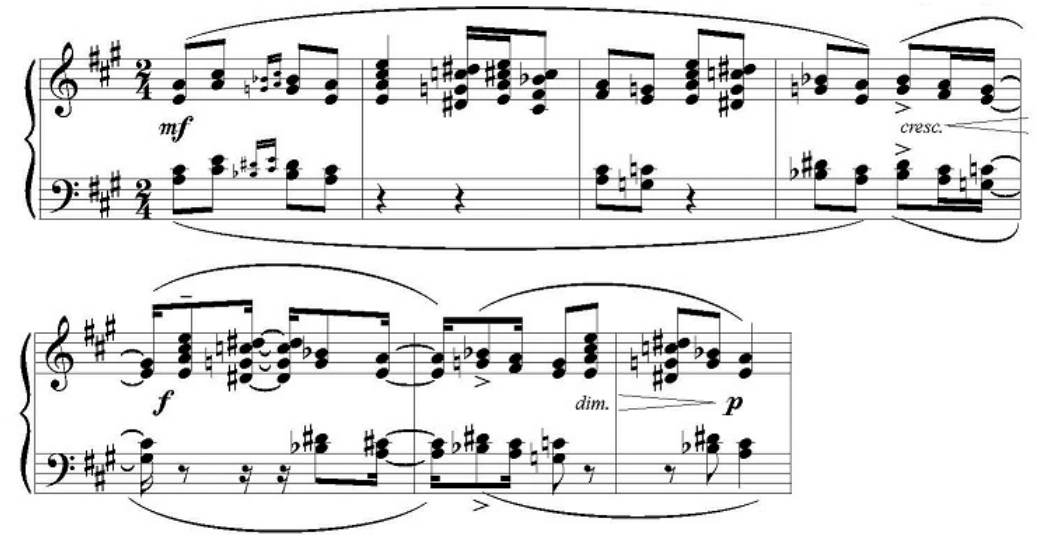

Messiaen continued developing the theme in this section of the piece, as "the melodic line [recurs] in the bass register, with a carillon in triple rhythmic ostinato." ${ }^{44}$ Symbolically, the composer attempts to reconcile the image of "angels prostrating themselves before God's throne," as the theme represents God the Creator, and the power of eternity comes through in the presentation of the rhythmic palindrome. ${ }^{45}$

The seriousness of tone in the fifth movement's restatement of the Creation theme suggests the awe of which the angels revere God. However, the most profound instance of thematic development that enabled Messiaen to symbolize the true power of Amen is found in the final movement of the cycle, "Amen de la Consommation." Not only does the thematic development in this section serve as a recapitulation; the composer considered this passage as "a counterpart of the creative act... [to serve as] framing movements [to] define the alpha and omega in the history of the created world." ${ }^{46}$

\footnotetext{
${ }^{43}$ Bruhn, 102.

${ }^{44}$ Bruhn, 101.

${ }^{45}$ Bruhn, 105-6.

${ }^{46}$ Bruhn, 87.
} 
The "omega in the history of the created world" is what the Book of Revelation depicts as the coming of a new age: "Then I saw a new heaven and a new earth, for the first heaven and the first earth had passed away, and there was no longer any sea." ${ }^{47}$ To represent this as a new Creation, Messiaen restates the theme in Piano II, though he varies it by making the tempo "more than twice as fast as when it was first heard." ${ }^{, 48}$ Rather than relying solely on octave displacement as was used in the first movement, the composer instead introduced a different perspective, using transposition from the original statement in A major to C\# major, then moving on to $\mathrm{F}$ major before finally returning to the home key. ${ }^{49}$

While the Creation theme in the final movement is noticeably different from its initial appearance and development in "Amen de la Création," so too are the aspects of the carillons distinct. Firstly, the chordal structure of the two strands is no longer symmetrically assembled, originally stacked vertically from low to high tritone-P4-tritone-P4-tritone, instead taking on a structure in which there are three-note chords in the upper carillon, accompanied by a two-note chord in the lower strand. Secondly, rather than both ostinati moving in the same direction, the two lines instead move in contrary motion, coming towards the center, as if God and humankind were moving towards each other. ${ }^{50}$ Finally, to continue the representation of God and His creatures moving toward each other in eternity, the distance between the two hands are now displaced further from each other on the piano. ${ }^{51}$

\section{Other Elements and Features: Birdsong and Color}

The thematic elements contribute a major part to Visions, yet birdsong and color also make an important impact that cannot be ignored. Indeed, Messiaen used these two components

\footnotetext{
${ }^{47}$ Rev 21:1.

${ }^{48}$ Bruhn, 88.

${ }^{49}$ Bruhn, 88.

${ }^{50}$ Bruhn, 90-1.

${ }^{51}$ Bruhn, 91.
} 
in an attempt to bring the listener closer to God, as the composer viewed birds as "intermediary beings, who, neither divine nor subject to sin, have devoted their whole existence to... prais[ing] God," 52 while the colors that Messiaen saw when he heard certain tones represented the stained glass windows that dazzled him as a child.

The most obvious allusion to birdsong of course can be found in the title of the fifth movement of the cycle, "Amen des anges, des saints, du chant des oiseaux," where Messiaen pays homage to the creatures along with the celestial residents of Heaven as well as the saints, who "[are] outstanding representatives of humans who are entirely devoted to the service of God... All three groups [have in common the fact they] transcend a life determined by selfabsorption and arrogance... [and, as] Messiaen seems to suggest, [they] achieve the state of 'just and elect' long before Judgment Day. "53

To symbolize sanctity with the birds in the fifth movement, the composer first establishes a relationship between them with the angels and saints. The first section of the movement features what Messiaen calls in his prefatory notes as "the singing of the angels and the saints," with both pianos are playing in unison a rhythmically free melody, synonymous to Gregorian chant. ${ }^{54}$ In the second part of the first section, a homophonic segment offers a reprise of the Creation theme and one of the carillons, which was previously described. By immediately following the chorus of angels and chorus of saints by means of the carillon, Messiaen thus unites these two groups. Once the relationship between the afterlife and the angels and saints has been made (beginning in measure 45) Messiaen unleashes a section of 104 measures in the Piano I part dedicated to birdsong, utilizing calls that mimic nature as they are highly repetitive and

\footnotetext{
${ }^{52}$ Bruhn, 95.

${ }^{53}$ Bruhn, 95.

${ }^{54}$ Bruhn, 101.
} 
rhythmically free. ${ }^{55}$

Messiaen's homage to the birds is apparent in the musical elements of the fifth movement, and the title and prefatory notes to this section also allude to the importance of these creatures. His allusion to color in the preface, however, is not as obviously enumerated, though he does speak of rainbows, as "the entire rainbow of the gems of the apocalypse" ${ }^{56}$ in his notes to the last movement, "Amen de la Consommation." While he did not specify the individual hues that he wanted to intimate in this section, the fact that he uses Mode 2 of his Modes of Limited Transposition (see Ex 3.6) throughout the movement offers some clues. In an interview with Claude Samuel, Messiaen specified he saw "blue-violet, ...shades of grey, cobalt blue,, and dark Prussian blue,... glints of purple-blue, gold, red, and ruby-red, and with mauve, black, and white stars. The dominant color is blue-violet." ${ }^{57}$

Ex. 3.6: Mode 2 from the Modes of Limited Transposition

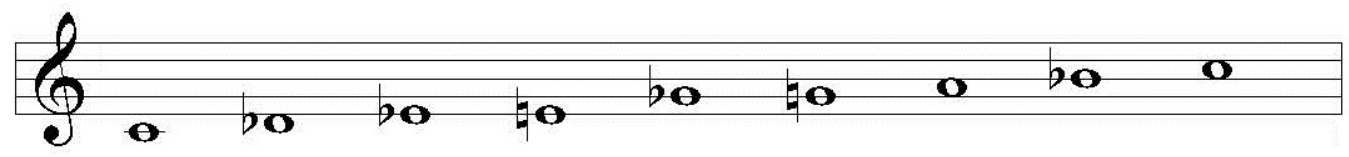

Messiaen used this richly-colored mode in the last movement because of the message he wanted to convey in describing the coming together of God and humankind in this consummation. The colors invoked by Mode Two brings to mind a specific scriptural passage, Revelations 21:16-20, in which St. John describes the sight of the City of God that emerges at the end of time: "The foundations of the city wall were decorated with every kind of precious stone. The first foundation was jasper, the second sapphire, the third chalcedony, the fourth

\footnotetext{
55 Bruhn, 104.

${ }^{56}$ Messiaen, Olivier Visions de l'Amen, trans. in Messiaen, Olivier, Works for Piano Duo -- Messiaen: Visions de l'Amen; Beethoven Grosse Fuge.

${ }^{57}$ Olivier Messiaen, Olivier Messiaen: Music and Color - Conversations with Claude Samuel, trans. E. Thomas E. Glasgow (Portland, OR: Amadeus Press, 1994): 64.
} 
emerald, the fifth sardonyx, the sixth carnelian, the seventh chrysolite, the eighth beryl, the ninth topaz, the tenth chrysoprase, the eleventh jacinth, and the twelfth amethyst."

Another brief allusion to the different colors can also be found to the notes of the second movement, "Amen des étoiles, de la planète à l'anneau," in which Messiaen referred to "the wonderful rainbow that enables Saturn's rings to shine." ${ }^{58}$ As one can see from the movement's opening (see Ex. 3.7), the notes include the members of Mode Two, suggesting that not only did the composer possibly see the same colors that he indicates in the fifth movement, but that he was drawing a connection between God, the celestial bodies of heaven, and humankind when the creation of a new world begins.

\section{Conclusion}

The elements of Messiaen's musical language had already been defined by the time Visions de l'Amen was composed; however, their refinement helped Messiaen introduce new forms of thematic development in his technique. Although other composers who preceded him had used this compositional practice extensively, for Messiaen this was a relatively new process. Combining the elements and adding the three themes used in the Visions allows the work to become a more unified whole. Thematic development would play a more important role in his next composition, Vingt Regards sur l'enfant Jesus.

\footnotetext{
${ }^{58}$ Messiaen, Olivier Visions de l'Amen, trans. in Messiaen, Olivier, Works for Piano Duo -- Messiaen: Visions de l'Amen; Beethoven Grosse Fuge.
} 


\section{Chapter Four}

Vingt Regards de l'enfant Jésus: Contemplations on the Divine

As the previous chapters on Quatuor pour la fin du Temps and Visions de l'Amen indicate, the religious beliefs Olivier Messiaen chose to share with his audience were limited to a small portion of Catholic theology: that which focused on the aspect of hope. Even as some of the Biblical and theological selections the composer had chosen at first glance may have seemed to be ones of despair (such as the end of the world in the Quatuor and the Jesus' Agony in the Garden at Gethsemane in the Visions), Messiaen looked at these scenarios in a positive light, as humans would be able to come closer to God through Jesus' death for their sins and during the Last Judgment. The overall optimistic viewpoint the composer took also prevails in his most extensive work for piano in the 1940s, the Vingt Regards de l'enfant Jésus (1944).

Although the religious aspects of the Vingt Regards are of primary importance, the genesis of the piece itself resulted from collaboration between the composer and Maurice Toesca (1904-88), a French writer who at the time worked as a bureaucrat of the municipal government of Paris and wrote mostly at his leisure. ${ }^{1}$ The idea for the two to work together was the brainchild of the director of Radio France, Henry Barraud, as he had planned a radio play on the Nativity with a script by Toesca that was to include some background music. ${ }^{2}$ When Messiaen and Toesca met in February 1944, the project was only in the planning stages, with the exact format unknown. Messiaen was not given an opportunity to see the complete manuscript or even an outline of Toesca's play. ${ }^{3}$ It appears that the layout of the drama, entitled Les douze Regards,

\footnotetext{
${ }^{1}$ Bruhn, Contemplations, 141.

${ }^{2}$ Edward Foreman, "L'Harmonie de l'Univers': Maurice Toesca and the Genesis of Vingt Regards sur l'enfant Jésus." In Olivier Messiaen: Music, Art, and Literature ed. Christopher Dingle and Nigel Simeone (Burlington, VT: Ashgate, 2007): 14.

${ }^{3}$ Bruhn, Contemplations 140 .
} 
(Twelve Gazes), was reached by the time Messiaen began writing the music in 23 March. ${ }^{4}$ The writer and the composer worked independently of each other throughout the spring and summer. Messiaen informed Toesca on 9 September that he had finished twenty-four pieces, going well beyond the scope of what Toesca had intended. ${ }^{5}$ The two met again a few days later at the house of mutual friend Guy Bernard-Delapierre, where Yvonne Loriod played the complete score, while between movements Messiaen would narrate from his preface. ${ }^{6}$ Although Toesca later wrote of the first performance that he was pleased with the composition, Messiaen would have to edit it in order to fit the parameters set forth by Toesca's work, and entries in Messiaen's diary as late as 16 November 1944 indicate that he was working with Toesca and Barraud to meet the requirements for the radio broadcast. ${ }^{7}$ Nonetheless, a few days later Barraud told Messiaen he did not conceive piano music to be an appropriate accompaniment for a radio play, whether or not the piece was edited to fit the play's content and structure; therefore, Messiaen's part of the project was scrapped. ${ }^{8}$

Regardless of how the plans for the radio play evaporated, Vingt Regards was given a formal premiére on 19 December 1944 at the concert hall of the Paris Conservatoire, with Loriod performing at the piano and Messiaen reading the prefatory notes of each movement. ${ }^{9}$ What truly inspired Messiaen to write well beyond the number of movements needed for Toesca's play comes from a work written in 1919 by Dom Columba Marmion (1858-1923), Le Christ dans ses mysteries (Christ in His Mysteries). The parallels between Messiaen's work and portions of Marmion's text are striking, unsurprisingly, since Marmion was known to espouse a "theological

${ }^{4}$ Foreman, 14.

${ }^{5}$ Foreman, 15.

${ }^{6}$ This is indicated in Toesca's diary entry of the performance, dated 12 September (trans. in Foreman, 15).

${ }^{7}$ Foreman, 16.

${ }^{8}$ Bruhn, 143.

${ }^{9}$ Bruhn, 143. 
tenor... wholly directed toward gratitude for God's abundant love," which was very similar to Messiaen's theology of glory. ${ }^{10}$

The parallels between the two works can easily be discerned by examining Messiaen's

Notes de l'Auteur that precede the Vingt Regards. The translated text follows:

Contemplation of the Infant-God in the manger and glances we set on Him: through the inexpressible contemplation of God the Father up to the multiple contemplations of the Church of Love, passing through the extraordinary contemplation of the Spirit of joy, through the tender contemplation of the Virgin, then of the Angels, the Magi, and of the incorporeal or symbolic creatures (Time, the Heights, Silence, the Star, and the Cross).

The Star and The Cross have the same theme because the one opens and the other closes the earthly period of Jesus.

Theme of the Star and the Cross:

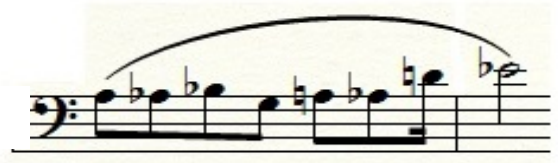

The Theme of God is found in the three pieces dedicated to the three persons of the Holy Trinity: "Regard of the Father", "Regard of the Son upon Himself", "Regard of the Spirit of Joy," in "Through Him All Things Were Made" it is present in "The Kiss of the Child Jesus" and in "First Communion of the Virgin" (She bore Jesus in her), it is magnified in "The Church of Love" which is the Body of Christ. Not to mention birdsongs, chimes, spirals, stalactites, galaxies, photons, and of the texts of Dom Columba Marmion, St. Thomas, St. John of the Cross, St. Therese of Lisieux, the Gospels and the Missal that have influenced me.

Theme of God:

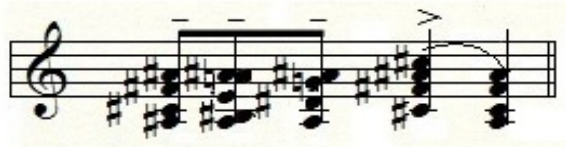

The Theme of Chords flows from one place to the other, fragmented or intensified, like a rainbow; we see rhythmic canons, polymodalities, nonretrogradable rhythms enlarged in two directions, values accelerated or slowed, asymmetric

\footnotetext{
${ }^{10}$ Bruhn, Contemplations 129.
} 
augmentations, changes of register, etc. - the piano writing is very searching: inverted arpeggios, resonances, a variety of arrows!

Theme of Chords:

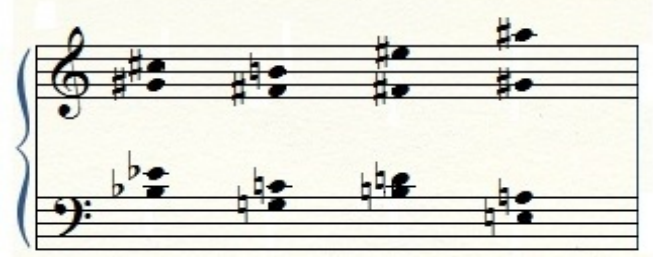

Dom Columba Marmion (Christ in His Mysteries) and after him Maurice Toesca (The Twelve Mysteries) spoke of contemplations of shepherds, angels, the Virgin, the heavenly Father: I have taken the same idea, using a different approach and adding sixteen new contemplations. More than in all my previous works, I have searched for a language of mystical love, which at times varies, powerful and tender, sometimes brutal, in a many-colored order.

I. Contemplation of the Father (Regard du Pére)

The complete statement of the Theme of God. And God said, "This is my beloved son, with whom I am well pleased ..."

II. Contemplation of the Star (Regard de l'etoile) Theme of the Star and the Cross. Shock of grace... the star shines naively, surmounted by a Cross.

III. The Exchange (L'echange)

Descending like a spray, rising like a spiral; a terrible intercourse between the human and the divine; God became man in order that we might return to God.

God is represented by the characteristic of alternating thirds: little moves, everything is small. Man is represented by other fragments that enlarge, enlargement becomes enormous, according to a procedure of development that I call "asymmetric augmentation."

IV. Contemplation of the Virgin (Regard de la Vierge) Innocent and tender... the woman of Purity, the woman of the Magnificat, the Virgin looks at her child...

I want to express the purity of music: this necessitated a certain power - and especially much simplicity and childish tenderness. 
V. The Contemplation of the Son upon Himself (Regard du Fils sur le Fils)

Mystery, rays of light in the night - refraction of joy, the birds of silence - the personification of the Word in one natural human being - marriage of the human and divine natures in Jesus Christ.

It is the notion of the Son-Word looking at the Son-child-Jesus. Three sonorities, three modes, three rhythms, three musics superimposed. Theme of God and rhythmic canon by adding a dot. Joy is symbolized by bird song.

VI. Through Him All Things Were Made (Par Lui tout a été fait) Abounding in space and duration: galaxies, photons, contrary spirals, inverted lightning; through Him (the Word) all things were made... in a moment the Creation opens to us the enlightened shadow of his voice.

This is a fugue. The subject is never presented in the same fashion: from the second entry it is changed in rhythm and registers. Notice the entertainment where the higher voice treats the Subject in nonretrogradable rhythm eliminated from the right and from the left, or the fortissimo bass repeats a fragment of the subject in asymmetric augmentation. In the middle section are some very short and very long values. (The small infinity, the large infinity). The reprise of the fugue is in retrograde, like a crab, a mysterious stretto. The Theme of God fortissimo: Victorious presence, the face of God behind the flame and effervescence. The creation replies and sings the Theme of God in a canon of chords.

VII. Contemplation of the Cross (Regard de la Croix) Theme of the Star and the Cross. The Cross said to Him: you will be taken in my arms...

VIII. Contemplation of the Heights (Regard des hauteurs) "Gloria in excelsis!" The heavenly glances descend upon the manger like the song of a lark. Songs of birds: nightingale, blackbird, warbler, finch, goldfinch, garden warbler, canary, and above all, the lark.

IX. Contemplation of Time (Regard du temps)

The mystery of the fullness of time: Time sees born in Him the one who is Eternal. A theme, short, cold, strange... a rhythmic canon.

X. Contemplation of the Spirit of Joy (Regard de l'Esprit du joie) Vehement dance, wild wound of horns, transport of the Holy Spirit - the Joy of the love of God blessed in the soul of Jesus Christ. I 
have always been impressed by the fact that God is happy - and that this ineffable and continuing joy lives in the soul of Christ. This joy for me is a transport, an intoxication, in the wildest of terms.

Form: Oriental dance, extremely solemn, in unequal neumes, like those of plainchant. This is followed by the first development on the Theme of Joy in asymmetric augmentation. It is followed by three variations of a hunting song. The second development of the Theme of Joy and the Theme of God takes place. Reprise of the Oriental Dance and neumes from the beginning, extreme high register and extreme low register together. The coda is based on the Theme of Joy.

XI. First Communion of the Virgin (Premiére communion de la Vierge)

A tableau where the Virgin is represented kneeling, leaning back in the night, a luminous halo over her womb. With closed eyes she adores the fruit of the manger within herself. This happens between the Annunciation and the Nativity: the first and greatest of all communions.

Theme of God glides sweetly in stalactites, in inner lines embraced by embellishments. Recalling from the theme of "The Virgin and the Child" from my work, "La Nativité de Seigneur," with a more enthusiastic Magnificat. Special chords and values of two by two played in the low register represent the heartbeat of the child in the womb of his mother fading in the Theme of God.

After the Annunciation, Mary adores Jesus within her ... My God, my Son, my Magnificat! - My love without the sound of words.

XII. The Almighty Word (La parole toute-puissante)

A monody with solemn percussion.

The Christ-child is the Word who sustains all things by the power of his speech.

XIII. Christmas (Noël)

Carillon - The bells of Christmas say with us the sweet names of Jesus, Mary, and Joseph.

XIV. Contemplation of the Angels (Regard des Anges)

Scintillations, drumbeats, powerful breathing in trombone-like immensity. Your servants are flames of fire - then the song of the birds that fly from out of the blue - and the amazement of the angels is growing because it is not them but a human race that God 
unites...

In the first three strophes: flamboyant, rhythmic canon and a fraction of the Theme of Chords. Fourth strophe: birdsongs. Fifth strophe: the angels' amazement deepens.

XV. The Kiss of the Infant Jesus (Le baiser de L'Enfant-Jésus)

At each communion, the Infant Jesus sleeps with us near the door; he then opens it onto the marvelous garden, and the light springs forth for us to embrace.

The Theme of God as a lullaby. Sleep - the garden - with arms outstretched toward love - the kiss - the hint of a kiss. An engraving inspired me, depicting the Infant Jesus leaving his mother's arms to embrace the young Sister Theresa. All this is a symbol of the communion, of divine love. It is necessary to love in order to love this subject and the music that seeks to be tender as the heart of the heavens, and nothing else.

XVI. Contemplation of the Prophets, the Shepherds, and the Magi (Regard des prophétes, des bergers et des Mages)

Exotic music: tam-tam and oboe, enormous and piercing concert.

XVII. Contemplation of Silence (Regard du silence)

Silence at hand, a rainbow thrown into confusion- each silence of the manger reveals music and colors that are the mysteries of Jesus Christ.

Polymodality, rhythmic canon by the addition of the dot, special chords, Theme of Chords. The entire piece is very pianistic in writing. End: alternating chords between the two hands, multicolored and ethereal music, with a confetti of light-colored gems reflecting upon each other.

XVIII. Contemplation of the Awesome Sacrament (Regard de l'Onction terrible)

The Word assumes a certain human nature, chosen by the flesh of Jesus by the dreadful Majesty. An old tapestry representing a scene from the Apocalypse: the Word of God in conflict under the features of Christ on a horse - one sees only his two hands on the hilt of the sword, which he brandishes in the middle of the flashes of lightning. This image influenced me. In the introduction and coda, values progressively made slower are superimposed with values progressively accelerated and inverted. 
XIX. I Sleep, But My Heart Keeps Watch (Je dors, mais mon coeur veille)

Poem of love, dialogue of mystical love. The silences play an important role.

It is not the angel's bow that smiles - it is Jesus sleeping who loves us on his Sunday and forgives us.

XX. Contemplation of the Church of Love (Regard de l'Eglise d'amour)

Grace makes us love God as God loves, after the sheaves of night, the spirals of anguish, there are the bells, the glory, the kiss of love - all the passion of our arms surround the Invisible...

Form: The development here precedes the exposition.

Development: First theme in nonretrogradable rhythm, enlarged from left and right. Three calls of the "theme of God" separated by asymmetrical augmentations. Development of the third melodic theme. The ringing of bells forms a pedal on the dominant, and a recall of the chords of previous pieces.

Exposition: Complete phrase on the Theme of God, in a fanfare of glory. A long Coda on the Theme of God-triumph of love and the tears of joy. ${ }^{11}$

As can be seen in the above translation of the cycle's preface, Messiaen includes three musical fragments as well as descriptions of devices used throughout the cycle. These elements will be discussed later in the chapter.

When comparing the Vingt Regards to Le Christ dans ses mystéres, the two seem to have some commonalities. Both the number of chapters and the number of movements in the piano piece are very similar. The organizing principles of both works are alike as well. Listed below are the chapters of Marmion's book:

Preliminary Chapters:

1. The Mysteries of Christ are our Mysteries

2. How We Assimilate the Fruit of the Mysteries of Christ

\footnotetext{
${ }^{11}$ Olivier Messiaen, Vingt Regards sur l'enfant Jésus, trans. in Dora Poulson Haslett, "The Harmonic, Rhythmic and Melodic Theories of Olivier Messiaen Utilized in the Vingt Regards sur l'enfant Jésus," (M.M. Thesis, University of Portland, 1965): 5-12.
} 
Part I: The Person of Christ

3. In the Father's Womb

4. The Word Has Become Flesh

5. Redemptor and High Priest

Part II: The Mysteries of Christ

6. Divine Preparations (Time of Advent)

7. O Marvelous Exchange! (Christmastide)

8. The Epiphany

9. The Blessed Virgin Mary, the Mysteries of the

Childhood and Hidden Life of Christ (Time after the Epiphany)

10. The Baptism and the Temptation of Jesus

11. Some Aspects of the Public Life of Jesus (Lent)

12. On the Heights of Thabor (Second Sunday of Lent)

13. "Christ...Loved the Church and Delivered Himself Up

for It. That He Might Sanctify It" (Passiontide)

14. In the Footsteps of Jesus from the Pretorium to Calvary [Stations of the Cross]

15. Si Consurrexistis cum Christo [If you have Risen in Christ] (Paschal Time)

16. "... And Now, Father, Glorify Thy Son" (Ascension)

17. The Mission of the Holy Spirit (Pentecost)

18. In mei memoriam [In Memory of Me] (Corpus Christi)

19. The Heart of Jesus Christ (Feast of the Sacred Heart)

20. Christ, Crown of all Saints (All Saints) ${ }^{12}$

The book is made up of a prologue and two subsequent sections. However, if one were to analyze the contents of the work, it could be divided into two major parts. The first five chapters serve as a philosophical foundation, with an introductory section -- chapters one and two -- and a discussion of "Christ's person and divine mission" in chapters three, four, and five. The subsequent fifteen chapters are organized to coincide with the liturgical calendar in terms of the life of the life of the Messiah, with the exception of the final chapter, which considers All Saints Day. ${ }^{13}$ Messiaen's Vingt Regards, according to musicologist Siglind Bruhn, is "also...separate[d]

\footnotetext{
${ }^{12}$ Columba Marmion, Les Christ dans ses mystéres, trans. in Siglind Bruhn, Messiaen's Contemplations of Covenant and Incarnation: Musical Symbols of Faith in the Two great Piano Cycles of the 1940s. From Dimension and Diversity: Studies in 20th Century Music, No. 7, Mark De Voto, ed. (Hillsdale, NY: Pendragon Press, 2007): 130-1. ${ }^{13}$ Bruhn, Contemplations, 131.
} 
internally [,] ... with [the first] five movements...function[ing] as a[n] exposition... [t]he remaining fifteen movements develop[ing] the theological and musical material." ${ }^{14}$ While it is obvious that the template of the Vingt Regards itself reflects the influence of Le Christ dans ses mystéres, the parallels do not end there. The subject matter and presentation also show Marmion's influence on the composer. Bruhn explains that both men communicate the subject matter and music in a horizontal and vertical dimension: to Marmion human time was the horizontal, while he referred to Christ's identity, nature, and role as the vertical. ${ }^{15}$ Marmion examined the horizontal view by presenting different meditations in the order of the feasts of the liturgical year, while he viewed the vertical arrangement as a way of "guid[ing] his readers' 'gaze' in a way directed by Church doctrine. ${ }^{16}$ Similarly, Messiaen looked horizontally, presenting the relationship between the Father and Son to appear in the very first movement ("Regard du Pére"), then later showing the relationship of Jesus as Man to Jesus as Word (movement three, "L'echange," and movement five, "Regard du Fils sur le Fils").

Examining the perspectives provided by the book and the music illuminates some similarities, but closer scrutiny of the actual spiritual content of both works brings other parallels to light. The individual reflections of both the writer and the composer included in their respective compositions show the greatest impact Marmion's ideas had on Messiaen. The author chose to include the viewpoints of those whom he considered most important at the time of Jesus' birth, such as the angels, the prophets, the shepherds, the Magi, and the Virgin Mary. ${ }^{17}$ These figures also appear prominently in Vingt Regards.

As there are strong parallels between the two works when it comes to those that gaze

\footnotetext{
${ }^{14}$ Bruhn, Contemplations, 131.

${ }^{15}$ Bruhn, Contemplations, 135.

${ }^{16}$ Bruhn, Contemplations, 135.

${ }^{17}$ Bruhn, Contemplations, 136.
} 
upon Christ, so too are the observations that both Marmion and Messiaen associate with specific perspectives of the various figures present at the Nativity. ${ }^{18}$ The inspiration for Messiaen's first movement, "Regard du Pére," appears to have originated from the seventh chapter of Marmion's book, where it states: "The Heavenly Father now contemplates His Incarnate Son. The Word, although made man, nevertheless remains God." ${ }^{19}$ Another example in which there is obvious influence from Marmion is in movement five, "Regard du Fils sur le Fils." This image, which Messiaen describes as the "Son-as-Word ('le Fils-Verbe') gazing down upon the Son-as-Infant Jesus ('le Fils -enfant-Jésus')," can also be traced to Marmion's book, where the monk explains that the Infant Jesus consents in his own acknowledgement of the life ahead of him as Scripture has described it. ${ }^{20}$

Other connections between the two works abound. One striking similarity relates to the role of the angels in both the book and the score. In the notes prefacing the fourteenth movement of Vingt Regards, Messiaen seems to suggest that in their contemplations, the angels' "astonishment border[s] jealousy... when they realize that the Word will be incarnated among humans rather than among them." ${ }^{21}$ A similar passage can be found in chapter seven of Le Christ dans ses mystéres, in which Marmion describes the angels to be thrown into a state of jealousy when confronted with the knowledge that Christ will be sacrificed for humankind's sins: "The Angels likewise contemplated the newborn Babe, the Word made Flesh. They saw in Him their God; this knowledge threw these pure spirits into... wonderment... for it was not to their nature that He willed to unite Himself." 22

While the correspondence between Marmion's and Messiaen's works is undeniable, it

\footnotetext{
${ }^{18}$ Bruhn, Contemplations, 136.

${ }^{19}$ Marmion, Les Christ dans ses mystéres, trans. in Bruhn, Contemplations, 136.

${ }^{20}$ Marmion, Les Christ dans ses mystéres, trans. in Bruhn, Contemplations, 137.

${ }^{21}$ Bruhn, Contemplations, 139.

${ }^{22}$ Marmion, Les Christ dans ses mystéres, trans. in Bruhn, Contemplations, 139.
} 
must be noted that Messiaen also found inspiration from Ernest Hello. As Messiaen's spirituality was solely based on a theology of glory, there were certain Scriptural passages to which he was attracted, such as in the tenth movement of Vingt Regards, "Regard de l'Esprit du joie," for which the prefatory notes state, "This joy for me is a transport, an intoxication, in the wildest of terms." 23 The very notion of joy as intoxication is not mentioned in Marmion's text; rather, the first chapter of Hello's Paroles de Dieu likens the experience of being filled with the Holy Spirit to drunkenness: "What others promise without delivering, what humans seek unto furor... the Holy Spirit gives. It gives drunkenness, drunkenness without regret... that fills instead of making empty." 24

The detailed notes that preface the Vingt Regards indeed show the great influence Marmion's and Hello's works had on the composer. The means by which the composer chose to convey the message of glory these authors espoused include compositional devices such as thematic development, rhythmic nuances, color, and numerology.

\section{Thematic Development}

By the time Messiaen was approached by Henry Barraud to compose the background music for the radio program on the Nativity, the composer had gained valuable experience in using thematic development as a unifying element in the work preceding this piece, the Visions. The compositional device was again to play an important role in unifying the Vingt Regards, as it would prove to be more challenging due to the greater length of the piece and the depth of the subject that the composer wished to portray.

The three main themes that Messiaen used can be placed in order of prominence in the

\footnotetext{
${ }^{23}$ Messiaen, Vingt Regards sur l'enfant Jésus, trans. in Haslett, 8.

${ }^{24}$ Ernest Hello, Paroles de Dieu, trans. in Siglind Bruhn, Messiaen's Contemplations of Covenant and Incarnation: Musical Symbols of Faith in the Two Great Piano Cycles of the 1940s. From Dimension and Diversity: Studies in 20th Century Music, No. 7, Mark De Voto, ed. (Hillsdale, NY: Pendragon Press, 2007): 140.
} 
score. Pointedly mentioned and notated in the Notes de l'Auteur, they consist of the Theme of God, the Theme of the Star and the Cross, and the Theme of Chords; all appear frequently throughout the composition. The composer also uses secondary themes, such as the Theme of Love, the Theme of the Kiss, carillon chords, and various birdsongs, which are not presented in the prefatory notes but nevertheless are briefly mentioned and play minor roles in the composition. $^{25}$

Theme of God. The first theme to make an appearance, the Theme of God, is made up of "five chords [with] a melodic ascent and descent between A-sharp and C-sharp [and] is used as the main organizing aspect of the entire collection." ${ }^{26}$ It first appears in movement one, "Regard du Pére," in which the Father is the first to contemplate the son, based on Matthew 3:17, "And God said: This is my beloved son in whom I am well pleased," which appears inscribed on the first page of the score.

The theme is characterized by an F-sharp major sonority (based on mode two of the Modes of Limited Transposition), a tertian- based harmony, and a 3+2+3 rhythm (based on eighth notes). ${ }^{27}$ The movement features the development of this theme, as it "progresses through each of its three transpositions," while the modality, sonority, and the overall arch-shape (a melodic ascent followed by descent) are all symmetrical, as "the F-sharp triad in its four-note form in first inversion... contains a central perfect fourth, and two thirds ${ }^{28}$ The structure of the first movement lends itself to the development of the theme, as it is "divided into two strophes [almost identical to one another] and a coda [, allowing the] natural culmination of dissonance,

\footnotetext{
${ }^{25}$ Bowlby, 15.

${ }^{26}$ Bowlby, 15.

${ }^{27}$ Christopher Bowlby, “Vingt Regards sur l'enfant Jésus: Messiaen's Means of Conveying Extra-Musical Subtext (DMA diss., Univ. of Washington, 2005): 16, 43.

${ }^{28}$ Bowlby, 16-7.
} 
elevated range, and dynamic intensity." ${ }^{29}$ As this movement is completely devoted to the exposition and development of the theme - the material is considered "omnipresent" with no intervening contrasting elements - one can make the assertion that this represents God's Love, always present and never wavering. ${ }^{30}$

The Theme of God is a central part of movements one, five, fifteen, and twenty, and plays a supporting role in six and ten. The occurrence of the theme in the fifth movement, "Regard du Fils sur le Fils," enabled Messiaen to portray two aspects of Jesus (as Word and as the Infant), as the musical segment appears in its entirety, with the rhythm doubled in value from the original presentation of eighth and quarter notes. He also "reduce[s the] attack density [as the chords of the theme] are now in a form that can be played by the left hand alone." ${ }^{11}$ As can be seen in Ex. 4.1, two separate lines of chords, the top line in mode six and the bottom line in mode four of the Modes of Limited Transposition, accompany the theme.

\footnotetext{
${ }^{29}$ Bowlby, 17.

${ }^{30}$ Siglind Bruhn, Images and Ideas in Modern French Music: The Extra-Musical Subtext in Piano Works by Ravel, Debussy, and Messiaen. From Aesthetics in Music, No. 6, ed. Edward Lippman. (Stuyvesant, NY: Pendragon Press, 1997): 240.

${ }^{31}$ Bowlby, 18.
} 


\section{Ex. 4.1: Theme of God in Regard du Fils sur le Fils}
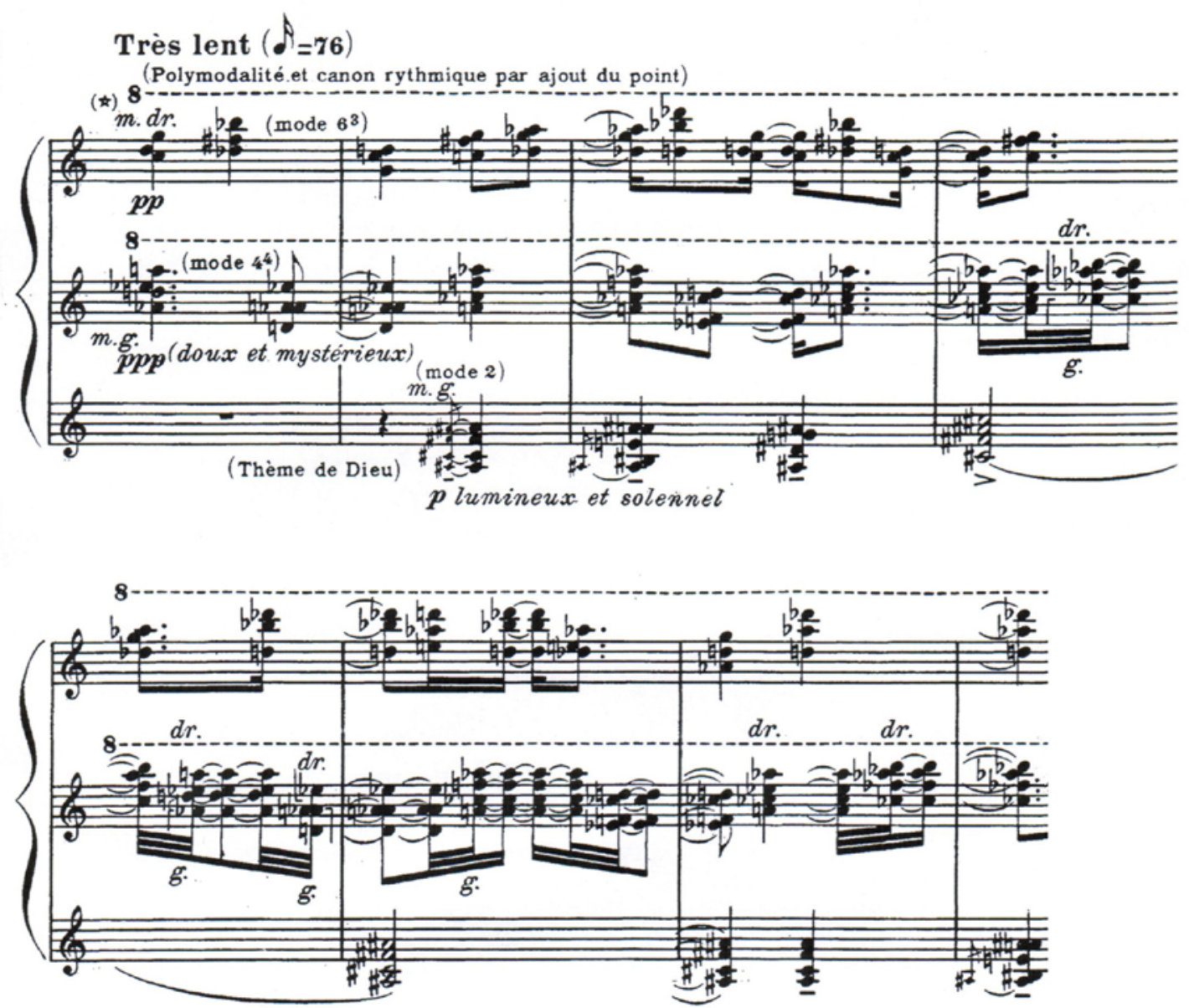

These two lines appear in a rhythmic canon and are to "depict two aspects of Jesus... the

Suffering on the Cross overshadowing the Incarnation of the Word." 32

While there are incidental appearances of the Theme of God in movements six and ten, ${ }^{33}$ its next major reintroduction occurs in movement fifteen, keeping the F-sharp tonal center but altering the melodic line and rhythm (see Ex 4.2).

\footnotetext{
${ }^{32}$ Bowlby, 19.

${ }^{33}$ Bowlby, 20. In movement six the theme plays a minor role in a fugue, while in movement ten two other themes take prominence over the Theme of God.
} 
Ex. 4.2: Theme of God in Movement

$\mathrm{XV}$, "Le baiser de l'Enfant-Jésus"

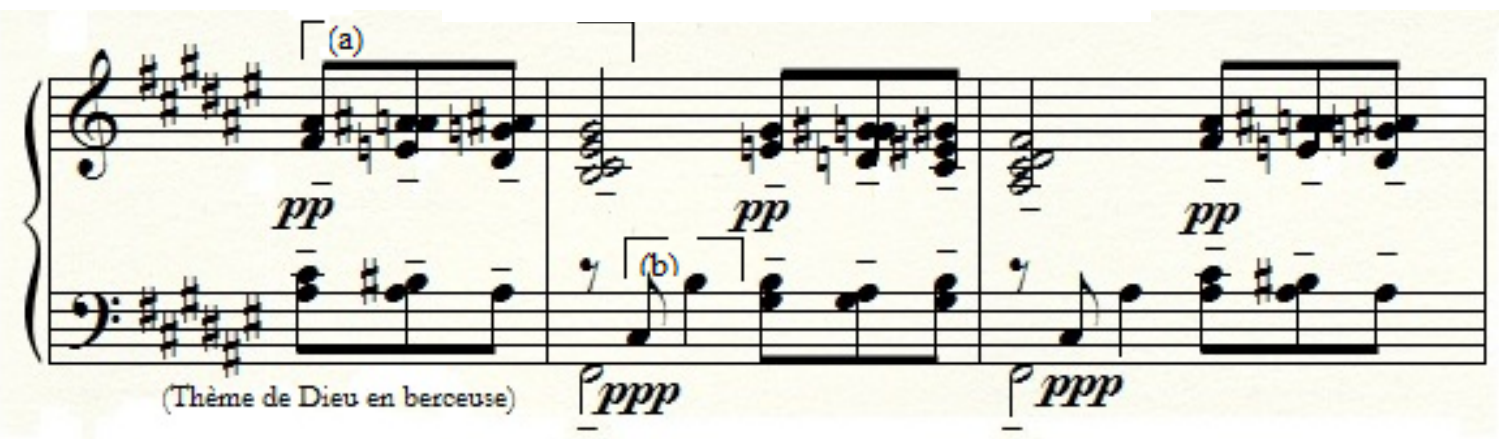

The shortened statement of the theme shown in [a] above is answered by a two-note motive shown in [b], marked as pianississimo, suggesting a lullaby. ${ }^{34}$ Here, Messiaen intended to symbolize Jesus asleep at the gates of Heaven, waiting for humanity to reunite with God in Eternity. After the statement is developed, undergoing various changes in tempi, the theme returns again in measure sixty-four, in the section marked Le jardin (The Garden). In this excerpt, the segment returns with its original melodic pitch content and rhythm, while the tempo is much faster than the beginning of the movement, a way in which Messiaen could portray Jesus rushing to open the garden's gate, bathed in the full light. ${ }^{35}$

The final appearance of the Theme of God can be found in the twentieth movement, Regard de l'Eglise d'amour. The segment does not appear until after an introduction of three nonretrogradable rhythmic passages, in which each succeeding entry is expanded from the previous one, the first as a three-note passage, the second in seven notes, and the final as a ninenote figure. ${ }^{36}$ As the theme emerges, it is extended as well, with the first chord extended by repetition (expanded from the original grouping of three sixteenth-note introduction to a group of

\footnotetext{
${ }^{34}$ Bowlby, 20. Indeed, Messiaen inscribed in the score, "Théme de Dieu en berceuse" (Theme of God in lullaby).

35 Bowlby, 20.

${ }^{36}$ Bowlby, 45.
} 
$2+3+3$ sixteenth notes), as if a fanfare. ${ }^{37}$ The idea behind this, according to Bruhn, comes from the mission of the Church to spread the Message of God. ${ }^{38}$

Theme of the Star and of the Cross. The predominance of the Theme of God in Messiaen's composition helps the composer to convey the importance of God's role, as $\mathrm{He}$ is one with Christ. The Theme of the Star and the Cross plays a less prominent part in the composition, as it only appears in movements two and seven. Although not as conspicuous as the Theme of God, this segment plays a crucial role in helping Messiaen present his theology, as it marks two important parts of Jesus' life, "[t]he comet announcing the birth... and the cross representing fulfillment of [His] mission among humans." ${ }^{39}$

The Theme of the Star and the Cross, as shown in the Notes de l'Auteur, is characterized by an eighth-note melody in a monophonic setting. ${ }^{40}$ The theme is based on the third transposition of the seventh mode of Messiaen's Modes of Limited Transposition (see Ex. 4.3). It is the only theme in the entire piece that is based on this particular mode.

Ex. 4.3: Mode Seven of the Modes of Limited Transposition

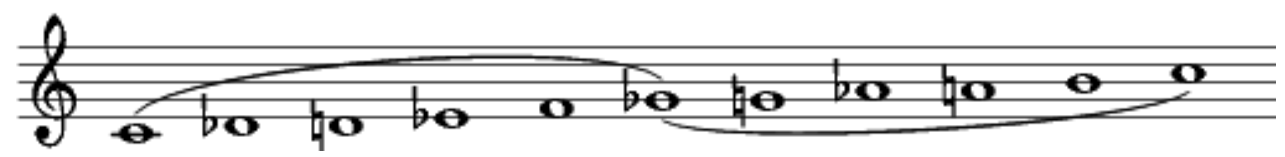

Messiaen purposely selected this mode for the specific reason that Mode Seven has an extensive relationship with the other Modes of Limited Transposition. Bruhn points out that one can derive from this mode other modes of limited transposition, (specifically, Modes Two, Four, and Six), simply by omitting one pitch in each tetrachord, as shown in Table 4.1:

\footnotetext{
${ }^{37}$ Bowlby, 45.

${ }^{38}$ Bruhn, Images, 260-9.

${ }^{39}$ Bruhn, Contemplations, 182.

${ }^{40}$ Bowlby, 28.
} 
Table 4.1: Mode Seven's Relationships to Other Modes of Limited Transposition ${ }^{41}$

\begin{tabular}{llllll|llllll} 
Mode $7^{3}$ & A-flat & A & B-flat & C-Flat & D-Flat & D & E-flat & E & F & G \\
Minus Pitch 1 & & A & B-flat & C-Flat & D-Flat & & E-flat & E & F & G & $=$ mode $6^{6}$ \\
\hline Mode $7^{3}$ & A-flat & A & B-flat & C-Flat & D-Flat & D & E-flat & E & F & G & \\
Minus Pitch 2 & A-flat & & B-flat & C-Flat & D-Flat & D & & E & F & G & $=$ mode $2^{2}$ \\
\hline Mode 7 & A-flat & A & B-flat & C-Flat & D-Flat & D & E-flat & E & F & G & \\
Minus Pitch 3 & A-flat & A & & C-Flat & D-Flat & D & E-flat & & F & G $=$ mode $6^{4}$ \\
\hline Mode 7 & A-flat & A & B-flat & C-Flat & D-Flat & D & E-flat & E & F & G & \\
Minus Pitch 4 & A-flat & A & B-flat & & D-Flat & D & E-flat & E & & G $=$ mode $4^{3}$ \\
\hline Mode 7 & A-flat & A & B-flat & C-Flat & D-Flat & D & E-flat & E & F & G & \\
Minus Pitch 5 & A-flat & A & B-flat & C-Flat & & D & E-flat & E & F & & $=$ mode $4^{4}$
\end{tabular}

As will be touched upon in the following discussion of the secondary themes, Modes Two, Four, and Six serve as symbols for God's love, the child of Bethlehem, and the Word Incarnate, respectively. ${ }^{42}$ The theme serves as a "liturgical chant linking the annunciation of Jesus' birth with a premonition of his Crucifixion," which therefore musically links the Theme of the Star and the Cross to "the human Jesus, the eternal Christ, and God's Love." ${ }^{43}$ These five measures recur twice more in the piece (mm. 18-22 and 35-39). ${ }^{44}$

The first appearance of the Theme of the Star and the Cross takes place in the second movement, "Regard de l'Étoile," where these distinct ideas are contrasted with each other (see Ex. 4.4).

\footnotetext{
${ }^{41}$ Bruhn, 155.

${ }^{42}$ Bruhn, Contemplations, 156.

${ }^{43}$ Bruhn, Contemplations, 192.

${ }^{44}$ Bruhn, Contemplations, 153.
} 
Ex. 4.4: Theme of the Star and the Cross in Movement II, "Regard de l'Etoile"
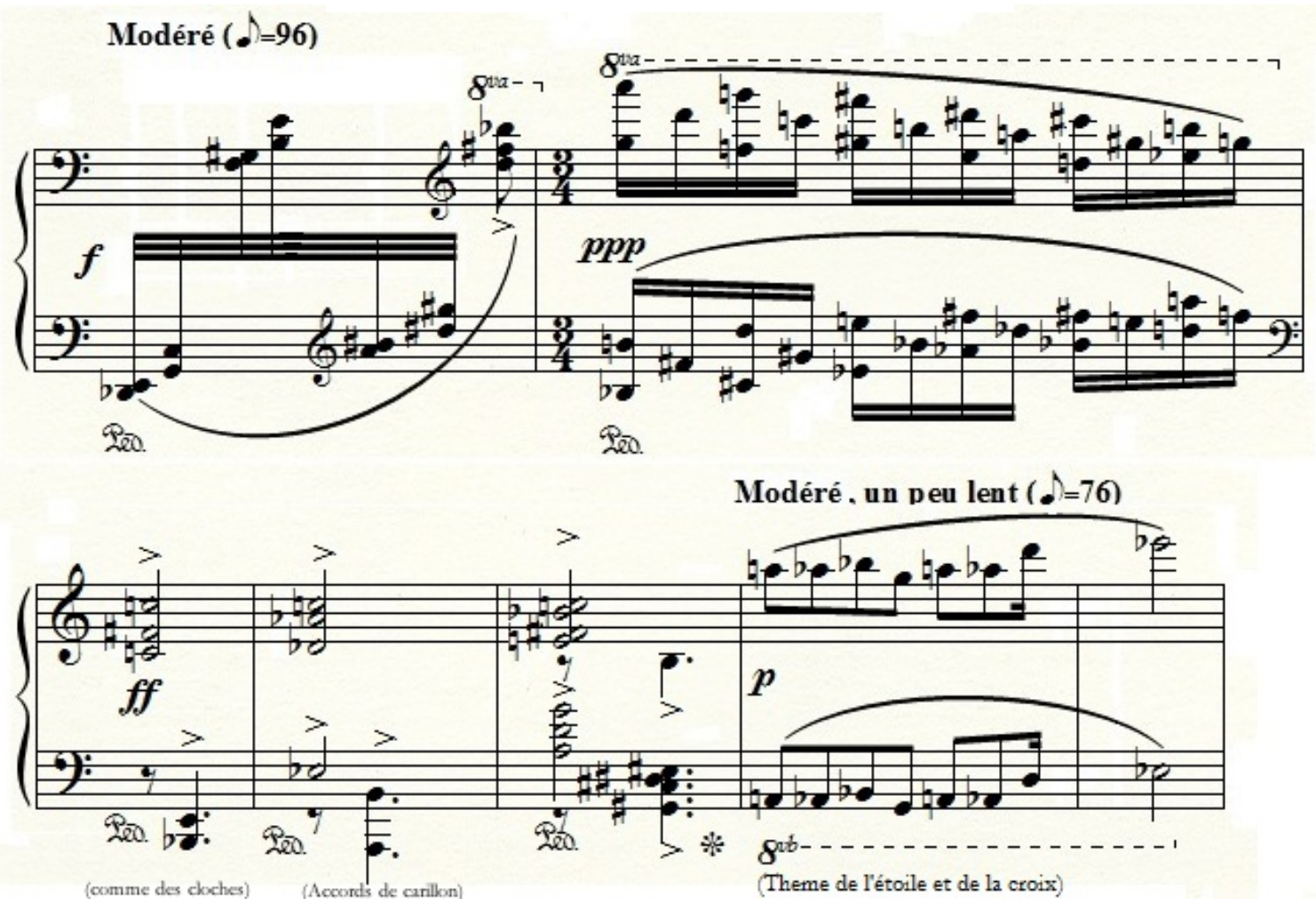

The presentation of the passage "is alternated with other musical elements presenting contrasting imagery... [a] violent observation, perhaps regarding the fate of the Son at the Cross... [and] a naïvely shining perspective provid[ing] a tempering contrast to the violent 'shock' element." 45 This "shock of grace" component, to which the composer refers in his preface, is a juxtaposition that Bruhn describes as astonishment that God would put His Son through a grisly death of crucifixion, partnered with the grace that God would be willing to do so to save humankind. ${ }^{46}$ The first five measures are marked with very distinct blocks that differ in "dynamics, continuity of motion, and pitch outline." 47 The section begins with an arpeggiated passage between hands in the first measure played forte, followed by one measure in which both hands, four-and-a-half octaves apart, play in pianississimo a passage of octaves alternating with single notes. It is then

\footnotetext{
45 Bowlby, 24.

${ }^{46}$ Bruhn, Contemplations 152.

${ }^{47}$ Bruhn, Contemplations, 153.
} 
followed by three measures of the comme des cloches (like bells) in fortissimo. ${ }^{48}$

After the initial statement of these five measures, the theme recurs regularly throughout the movement, first in mm. 6-17, in which it occurs in five developmental segments. Its next appearance (mm. 23-34), appearing after a reprise of mm. 1-5, is varied. ${ }^{49}$ The final occurrence of the melody comes at the conclusion (mm. 35-41), in which it is placed in an organum setting, as the melody is set with "accompanying parallel voices." ${ }^{50}$ The formal plan of the movement, therefore, can be diagrammed as follows:

Table 4.2: Formal Design of Movement II, "Regard de l'Étoile"51

\begin{tabular}{|c|c|c|c|c|}
\hline Section 1 & Section 2 & Section 3 & Section 4 & Section 5 \\
\hline $\mathrm{mm} .1-5$ & $\mathrm{~mm}$. 6-17 & $\mathrm{mm}$. 18-22 & $\mathrm{mm} .23-24$ & $\mathrm{~mm} .35-41$ \\
\hline "shock" & $\begin{array}{c}\text { Theme of the } \\
\text { Star and the } \\
\text { Cross in six } \\
\text { segments }\end{array}$ & "shock" & $\begin{array}{c}\text { Variation of the } \\
\text { Theme of the } \\
\text { Star and the } \\
\text { Cross }\end{array}$ & $\begin{array}{c}\text { "shock" with } \\
\text { organum coda }\end{array}$ \\
\hline
\end{tabular}

The manner in which this movement is cast likens it to a rondo form; however, according to Bruhn, because of the inconclusive nature of the coda, the third and final statement of the Theme of the Star and the Cross should be presented here. Instead of doing so, however, Messiaen saves the final declaration of the theme (this time heard only once, but without interruption) for the seventh movement, "Regard de la Croix." This action helps establish a link between the two movements, as it helps bring a symbolic closure to the shock of the Crucifixion with the grace of God's forgiveness of humankind's sins. ${ }^{52}$

Theme of Chords. As the Theme of the Star and of the Cross is not as discernible as the

\footnotetext{
${ }^{48}$ Bowlby, 24-5.

49 Bowlby, 29.

${ }^{50}$ Bowlby, 29.

51 Bowlby, 29.

52 Bruhn, 156.
} 
Theme of God because it is only used in two of the Regards, the Theme of Chords is also less prominent, if for a different reason. Although it appears more often in the entire cycle than either of the other themes, the succinctness of the Theme of Chords makes it "difficult to detect [because of its] typical placement in densely chromatic contexts which tend to camouflage its use... [It is] fragment[ed] and concentrat[ed]... in a variety of configurations." ${ }^{53}$ Unaltered, (as it appears in the fifteenth movement, "Le Baiser de l'Enfant Jésus "[Ex. 4.5]), it is composed of four chords, each of which can be considered its own pitch-class, with all twelve pitch-classes represented, with some duplication of pitches. ${ }^{54}$

Ex. 4.5: Theme of Chords as Grouped in Pitch Classes ${ }^{55}$

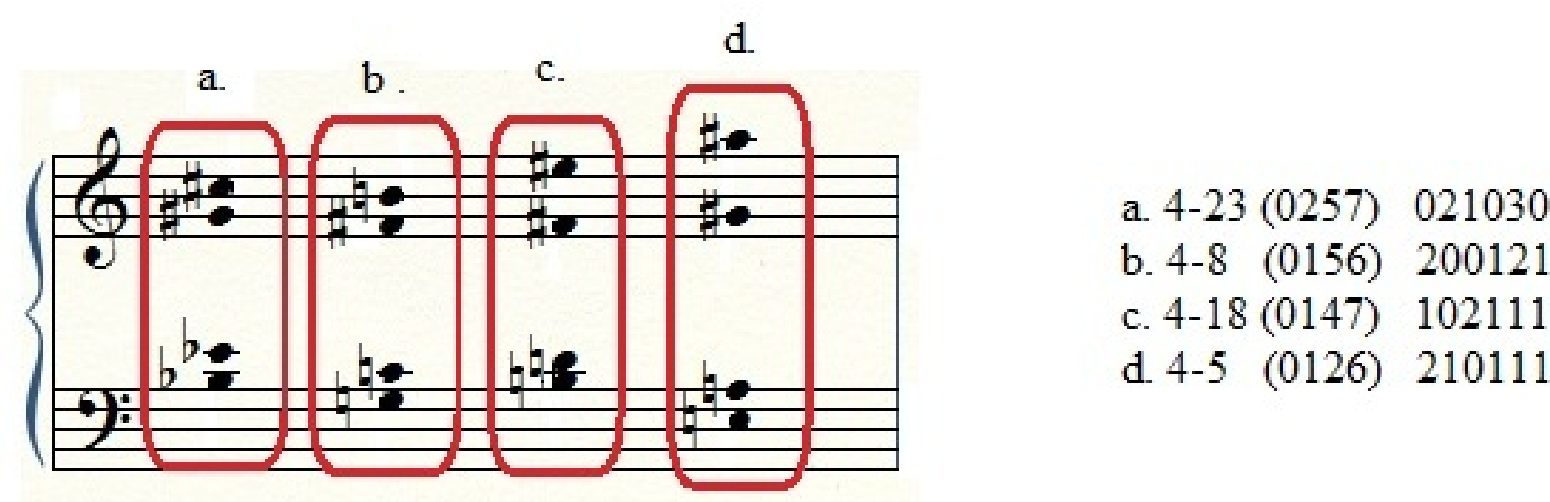

There are a myriad number of ways in which this theme is presented, all of which play an integral part of Messiaen's compositional technique used to express his beliefs. One of these ways can be seen in the fourteenth movement, "Regard des Anges." The movement consists of six stanzas and a coda; the stanzas can be further divided into a first section of three large stanzas

\footnotetext{
53 David Rogeson, "Aspects of Structure in Olivier Messiaen's Vingt Regards sur l'enfant Jésus," (DMA diss., University of British Columbia, 1996): 45.

${ }^{54}$ Rogeson, 46.

${ }^{55}$ Rogeson, 46.
} 
followed by a second section of three smaller stanzas. ${ }^{56}$ The appearance of the Theme of Chords takes place in the initial section (stanzas one, two, and three). The first occurrence, in measure five (see Ex. 4.6a), is played in the middle register of the instrument, is tonally complete, and is set in a syncopated rhythm of thirty-second note, double-dotted eighth note, thirty-second note, double-dotted eighth note.

\section{Ex. 4.6a: Theme of Chords, Movement XIV, "Regards des Anges"}

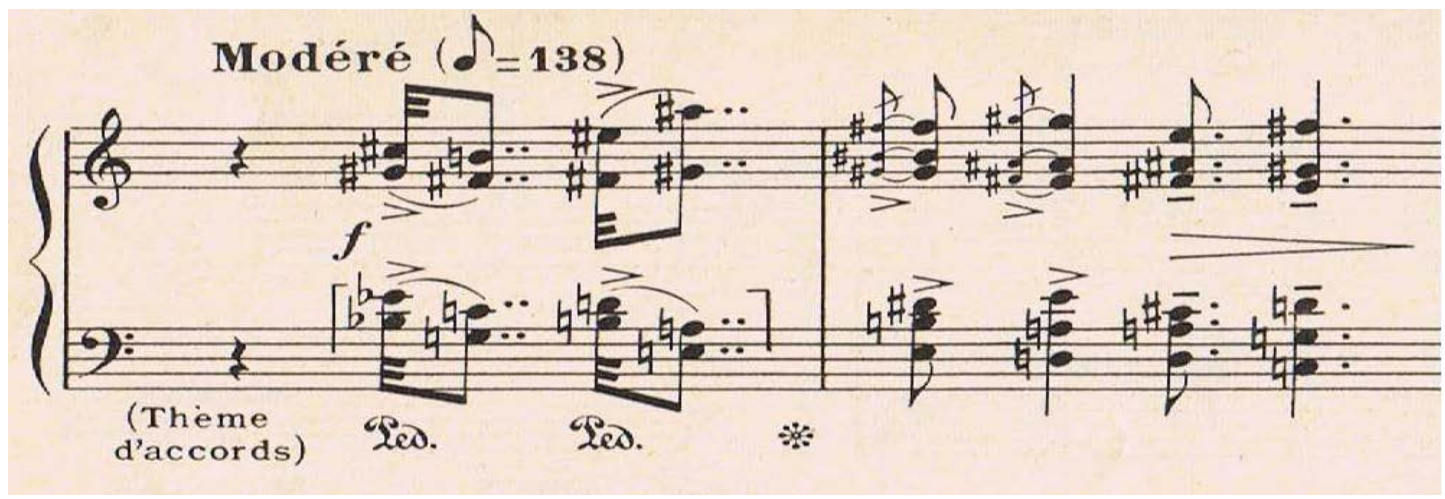

This presentation provides enormous contrast to the first four measures, (characterized by a flourish of thirty-second notes in perpetual motion featured in the upper octaves of the piano), and measures seven and eight, which are comprised of a tremolo in the high range accompanied by a short ostinato-like staccato pattern in the low bass. These distinguishing sections are intended to display the contrasts that Messiaen intended in the preface: the first four measures are the flashing of the stars, while measures seven and eight are the beating of the angels' drums. ${ }^{57}$ Placing the Theme of Chords in the middle of these two passages serves as an added way for the composer to offer contrast, and "point to the intermediate realm, the level between the divine and the human spheres, to manifestations of God's power that are neither the Word

\footnotetext{
${ }^{56}$ Bruhn, Contemplations, 238.

${ }^{57}$ Bruhn, Contemplations, 238-9.
} 
itself nor humankind to whom the Word is sent." 58

Messiaen placed the second variant of the Theme of Chords shortly after the presentation of the original theme. As seen in Ex. 4.6b, the theme is now presented in fragmented form in measure sixteen.

Ex. 4.6b: Theme of Chords, Fragmented, Movement XIV, "Regards des Anges"

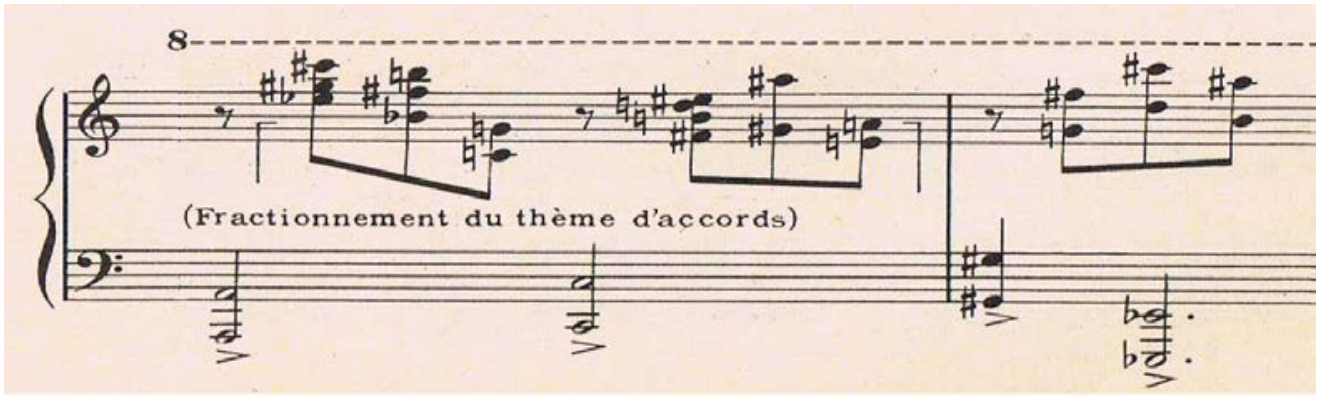

It is preceded by a three-part rhythmic canon that was intended to "symbol[ize]... the manifestation of the eternal in time (and thus an aspect of Jesus)." ${ }^{59}$ Bruhn argues that this rhythmic canon symbolizes the angels' growing understanding that Jesus' will meet his fate, and the interruption of the fragmented Theme of Chords serves as a way to symbolize their struggle with accepting the Crucifixion as the ultimate sacrifice for humankind's sins. ${ }^{60}$

\section{Secondary Themes and Birdsong}

The breadth of the Vingt Regards as a large cycle allowed Messiaen to use many of the elements of his musical language to the greatest extent possible. The above discussion of the main themes of the entire piece shows the composer had mastered the art of using thematic development not only as a unifying device, but also as an effective way in helping convey his religious beliefs.

The secondary themes mentioned in the preface to the score are actually derivations of the

\footnotetext{
${ }^{58}$ Bruhn, Contemplations, 238.

${ }^{59}$ Bruhn, Contemplations, 240.

${ }^{60}$ Bruhn, Contemplations, 240-1.
} 
Theme of God and the Theme of Chords. Table 4.3 shows the relationships between the primary themes and the secondary ones derived from them: ${ }^{61}$

Table 4.3: Relationships of

Primary and Secondary Themes

\begin{tabular}{|l|l|}
\hline Primary Themes & Secondary Themes \\
\hline \multirow{4}{*}{ Theme of God } & Theme of Love \\
\cline { 2 - 2 } & Theme of the Kiss \\
\cline { 2 - 2 } & Theme of Joy \\
\hline Theme of Chords & Carillon Chords \\
\cline { 2 - 2 } & "Motif \#270" \\
\hline
\end{tabular}

Secondary Themes Derived from the Theme of God. Two of the themes derived from the Theme of God, the Theme of Love and the Theme of the Kiss, share essential features with its parent. The Theme of Love originates from the "four final chords of [the] second conclusion of [the Theme of God presented in "Regard du Père"], a modal embodiment of an authentic cadence [see Ex. 4.7a]. ${ }^{92}$ This theme is presented in what Bruhn considers "the modal embodiment of God's love," Mode Two of the Modes of Limited Transposition, of which "[its] interval sequence is repeated on the equidistant tones of the diminished-seventh chord," and therefore is an expression of "the divine perfection epitomized." ${ }_{63}$

\footnotetext{
${ }^{61}$ Rogosin, 35.

${ }^{62}$ Bruhn, Contemplations, 151.

${ }^{63}$ Bruhn, Contemplations, 190, 150-1.
} 
Ex. 4.7a: Theme of Love in Movement I, "Regard du Père"
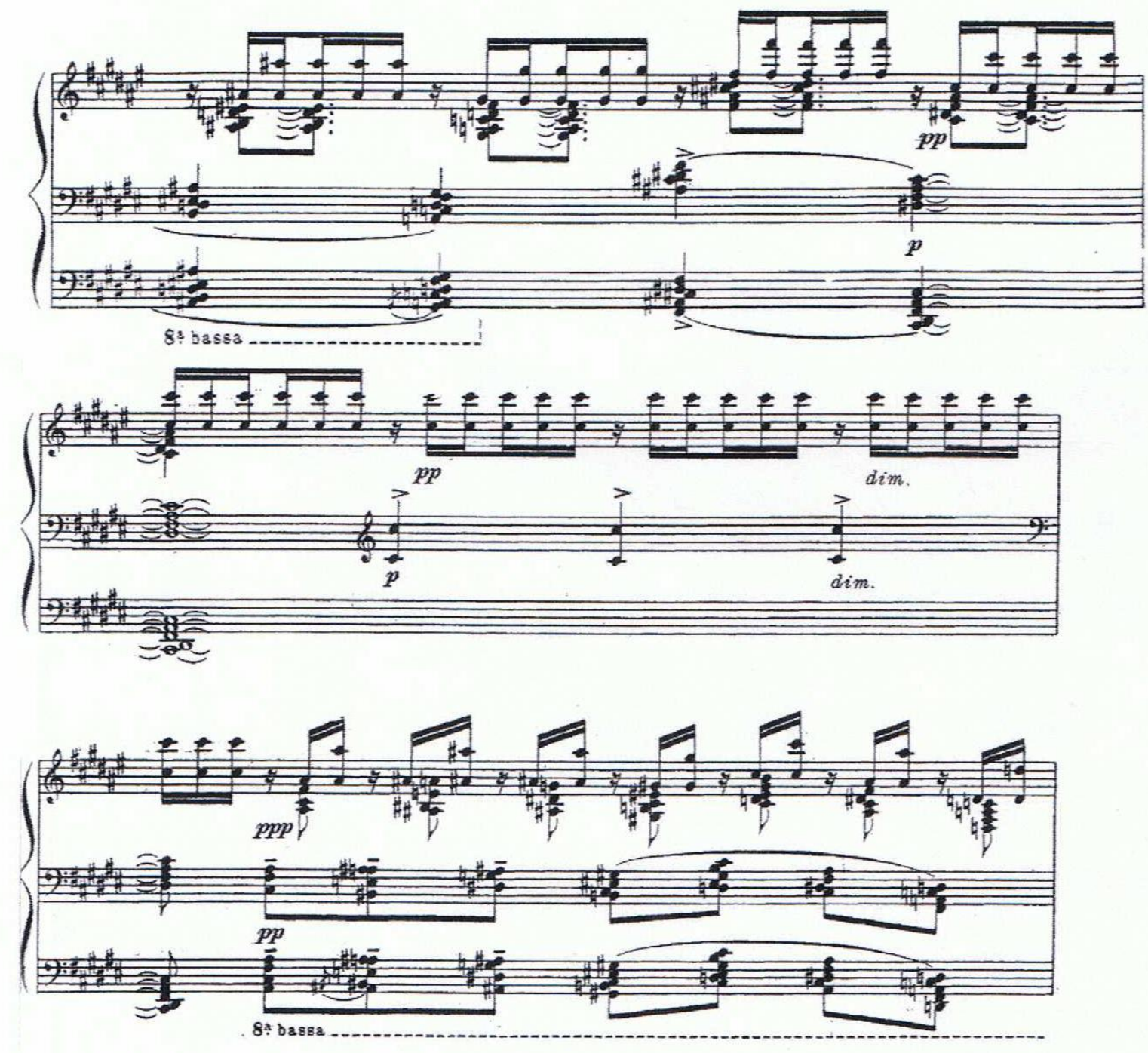

Although not specifically identified when first presented in the beginning movement, the composer does identify it when it reappears in the sixth movement onward. ${ }^{64}$ The appearance of this secondary theme, whether explicitly labeled or not, "are... perceived as signifiers of God's love." ${ }^{65}$

This presentation of the Theme of Love is a shortened version of that which is heard in the sixth movement, "Par Lui tout a été fait" (see Ex. 4.7b).

\footnotetext{
${ }^{64}$ Bruhn, Contemplations, 151.

${ }^{65}$ Bruhn, Contemplations, 150.
} 


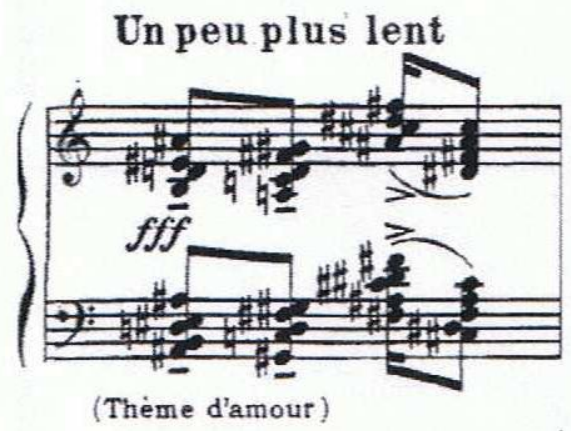

On the other hand, the long form, found in the nineteenth movement, "Je dors, mais mon coeur veille," seems to have more in common with its parent theme, as it, too, has "three initial descending chords, repeated, [with] a leap up to a strongly accented high point[,] and a fall back to a sustained tonic [see Ex. 4.7c]." 66

\section{Ex. 4.7c: Theme of Love, Long Form}

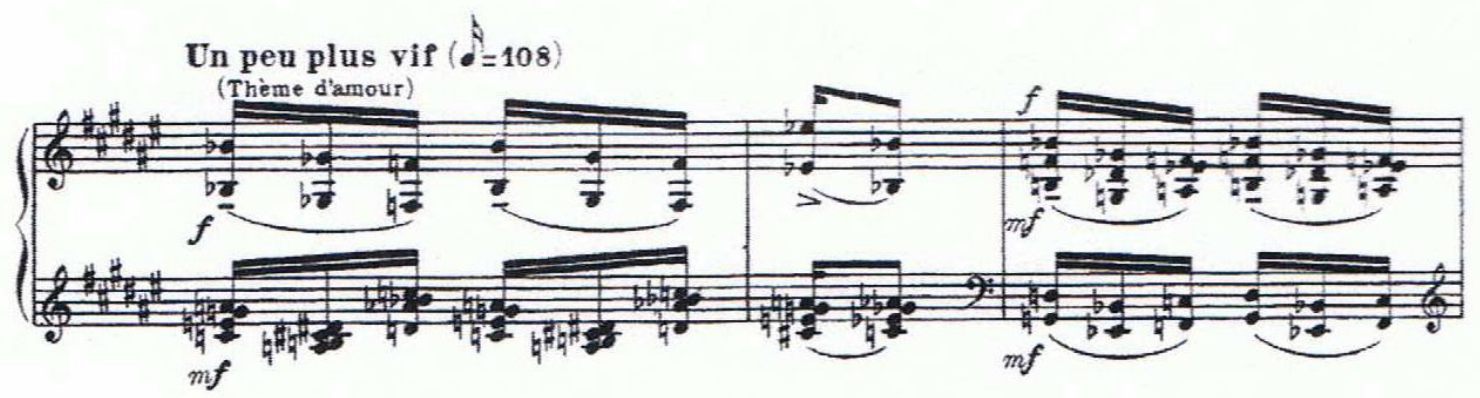

The short form is used in a context that symbolizes an enthusiastic joy, as denoted in its appearance in the tenth movement, Regard de l'Esprit du joie, as the passage marked "comme un air de chasse, comme des cors" (like a hunting tune, like horns). ${ }^{67}$ The long form, however, fully expressed in the nineteenth movement, "Je dors, mais mon couer veille," is a depiction of "quiet, floating timeless contexts." ${ }^{68}$

While the Theme of Love is used as an obvious complement to its parent to symbolize

\footnotetext{
${ }^{66}$ Rogosin, 40.

${ }^{67}$ Rogosin, 40.

${ }^{68}$ Rogosin, 41.
} 
God's eternal love for His Son, the Theme of the Kiss (marked only as "Le baiser" in the score), represents "the love experienced already by the newborn for the whole of humanity whom it has come to redeem." ${ }^{99}$ This theme, like the Theme of Love, also uses Mode Two of the Modes of Limited Transposition, (in its second transposition, however), and also features "three descending chords (underscored with tenuto marks) leading to an accented high note which subsequently falls[, and] a... traditional harmonic structure: Tonic, Subdominant, Tonic, Dominant, Tonic, Dominant." ${ }^{70}$ This theme makes its appearance in the fifteenth movement, "Le baiser de l'Enfant Jésus," and is characterized by a "[right-hand] melody in triads, [placed over a left-handed accompaniment] in ascending arpeggios [see Ex. 4.8]."1 The appearance of this theme here enables Messiaen to cast this movement as "a dialogue of mystical love," as it allows for the composer to express "the [Christ-] child's loving willingness to rush out into the world and embrace humankind." 72

\footnotetext{
${ }^{69}$ Bruhn, Contemplations, 145.

${ }^{70}$ Rogosin, 41.

${ }^{71}$ Bruhn, Contemplations, 189.

${ }^{72}$ Bruhn, Contemplations, 190.
} 


\section{Ex. 4.8: Theme of the Kiss}
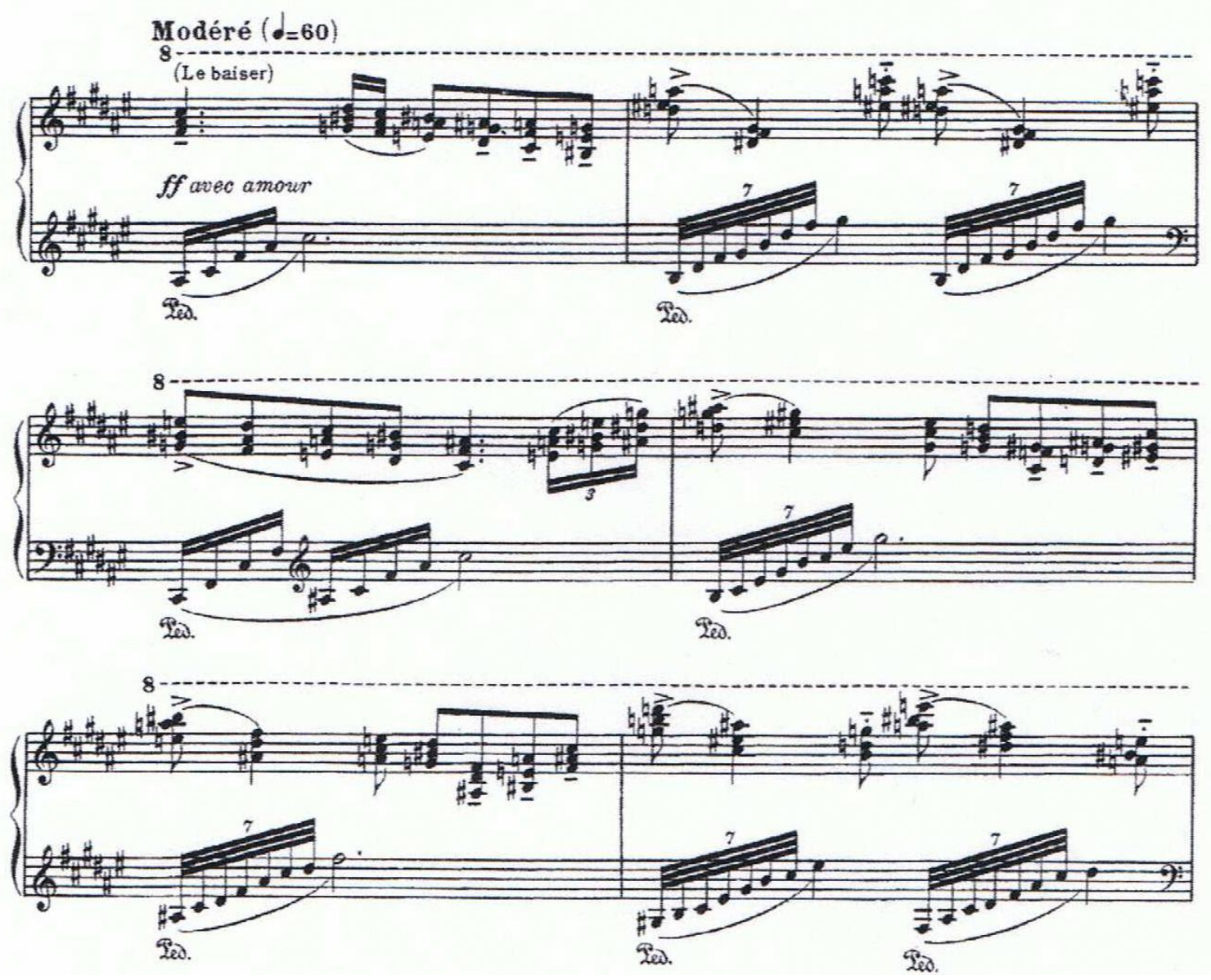

The final secondary theme that derives itself from the Theme of God, the Theme of Joy, has a complex relationship with its parent in that it is a strict rhythmic retrograde, with a loose backward restatement of the first seven notes presented in the Theme of the Kiss. ${ }^{73}$ It appears only in the tenth movement, the Regard de l'Esprit de joie, and has two different versions: an "unadorned version" (see Ex. 4.9a) and a "harmonized and extended version," featured in Ex. 4.9b. ${ }^{74}$ This theme is presented along with the Theme of God and the Theme of Love, along with birdsong (to be discussed below) enabled Messiaen to express the "exuberance of divine joy at the birth of the Son of God... unit[ing... representations of rapture with emblems of God's

\footnotetext{
${ }^{73}$ Rogosin, 43.

${ }^{74}$ Rogosin, 44
} 
love. ${ }^{75}$

Ex. 4.9a: Theme of Joy, Unadorned

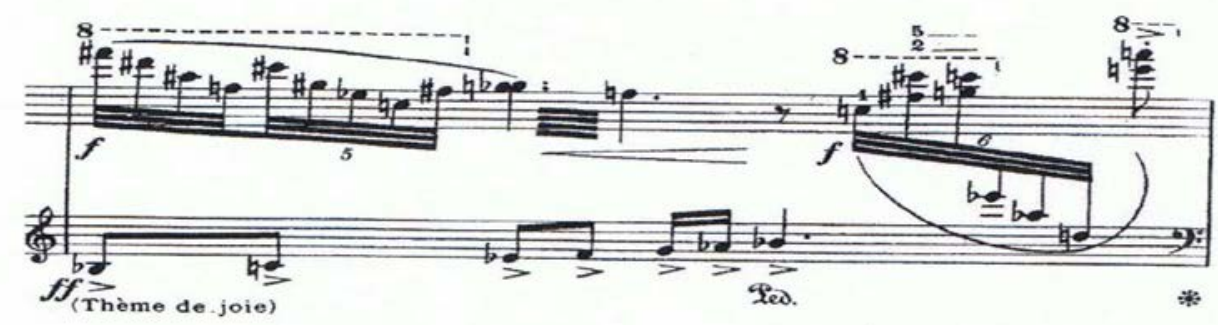

${ }^{75}$ Bruhn, Contemplations, 232. 
Ex. 4.9b: Theme of Joy, Harmonized and Extended

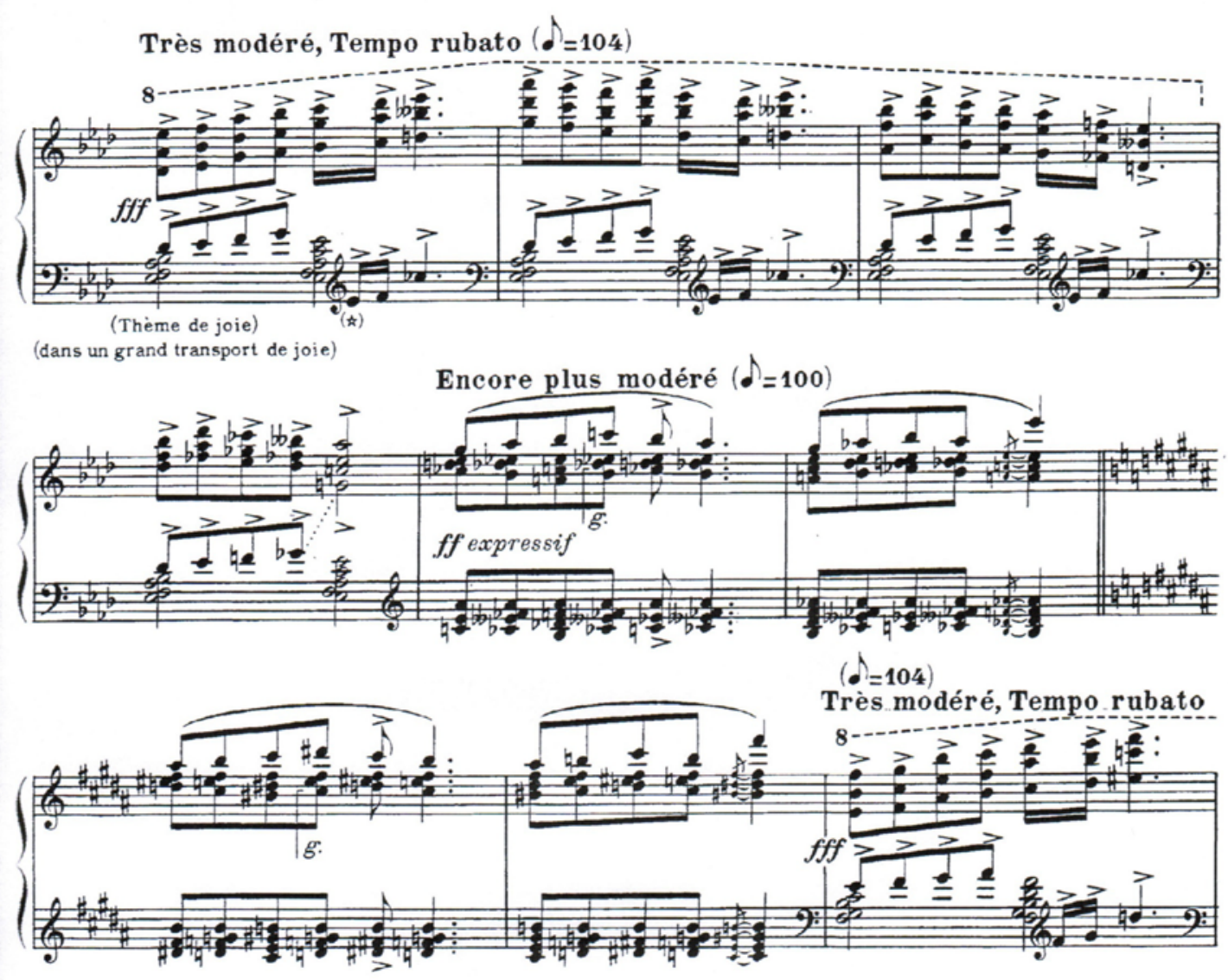

Secondary Themes Derived from the Theme of Chords. Compared to the themes

derived from the Theme of God, the Carillon Chords (see mm. 3-5 in Ex. 4.4) and Motif \#270, which spawn from the Theme of Chords (Ex. 4.10), "var[y] from [movement to movement], and even between repetitions within one [section] (as does [its parent]).”76

\footnotetext{
${ }^{76}$ Rogosin, 50.
} 


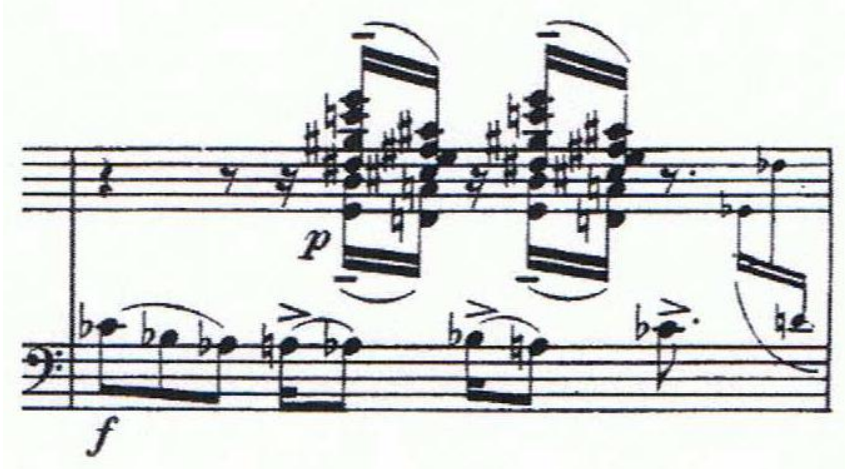

As can be seen by comparing the three members of this thematic family, they all share an alto voice movement of G\#-F\# and/or vice-versa, and have descending two-chord interjections. ${ }^{77}$ Both themes are featured in movement two, Regard de l'etoile, to enhance the contrast between the "shock" and acceptance that is partnered together in the Theme of the Star and the Cross, before which the Carillon Chords are stated (see Ex. 4.4). Motif $\# 270^{78}$, however, is heard in conjunction with a variant of the Theme of the Star and the Cross (see Ex. 4.10).

Birdsong. The fact that Messiaen believed birds to be sacred creatures and messengers from heaven has already been touched upon in Chapters Two and Three. This philosophy is also clearly evident in the Vingt Regards, as several occurrences of birdsong appear throughout the work.

The first appearance of birdsong occurs in "Regard du Fils sur le Fils", as "the entrance of ... soft chirping of birds interrupts" a three-part medieval motet where the Theme of God acts as the cantus firmus. ${ }^{79}$ The intrusion of birdsong here (as in other "pieces in which birdsong predominates") symbolizes "the action of God in nature," as the "manifestation of divine love" is

\footnotetext{
${ }^{77}$ Rogosin, 50.

${ }^{78}$ The moniker for this theme is derived from Example \#270, found in Technique de mon langage musical.

${ }^{79}$ Bowlby, 32.
} 
present in God's creatures. ${ }^{80}$

Messiaen also introduced birdsongs elsewhere to symbolize the divine in nature. This heavenly music appears in the eighth piece of the cycle, Regard des hauteurs. As the composer indicated in the preface to the piece, the songs of several birds "descend upon the manger" from above, those of the "nightingale, blackbird, warbler, finch, goldfinch, garden warbler, canary, and... the lark." ${ }^{81}$ Within the movement itself, the songs of three different birds are actually identified by the composer (the nightingale, the lark, and the blackbird, respectively). By associating the heights with the birds, the composer asserted his beliefs to show his audience that the birds indeed are heavenly creatures.

As the perspective of the birds viewing Christ reinforced the allusion of the sanctity of the birds, the final occurrence of birdsong in the entire cycle, Regard des Anges (Movement Fourteen), also refers to their sacredness by having their songs appear with the music associated with the angels. As explained in the earlier discussion of the Theme of Chords, the angels ponder the fate that Christ will indeed be sacrificed to save the human race. The songs of the birds enter as part of the second group of three stanzas, "serving to depict the heavens and heavenly entities... [and] also suggest the imagery of angelic flight." ${ }^{82}$

\section{Rhythm}

Using many different themes along with birdsongs in Vingt Regards provides one with a legend to a map of Messiaen's spiritual world, as these compositional devices are not only clearly denoted in the prefatory notes, but in the score as well. The composer used other means to help make clear his theology of glory, of which rhythm played a very important part. Indeed, as this document has revealed, this particular component of Messiaen's compositional procedure

\footnotetext{
${ }^{80}$ Robert Sherlaw Johnson, Messiaen (London: Dent, 1975): 41.

${ }^{81}$ Messiaen, Vingt Regards sur l'enfant Jésus, trans. in Haslett, 7.

${ }^{82}$ Bowlby, 33.
} 
played a major role in both the Quatuor and the Visions, since the composer again relied on these elements of his unique rhythmic language to emphasize his religious beliefs. The components upon which the composer called include nonretrogradable and palindromic rhythms, rhythmic canons, and added values.

As a symbol of Eternity, nonretrogradable rhythms abound in this particular cycle, as its recurrence was necessary to evoke images of the Eternal emanating from God. The very nature of outward growth (in equal proportions) generates from a center, "a universally important concept in many religions [as it] represent[s]... eternity...[and] heaven and hell, which intersect in a central...point." ${ }^{13}$ One section that exemplifies this type of expansion from the nucleus can be considered in the first movement, where the Theme of God is tied across the bar line to an eighth note, as illustrated in Ex. 4.11:

Ex. 4.11: Theme of God as a Palindromic Rhythm

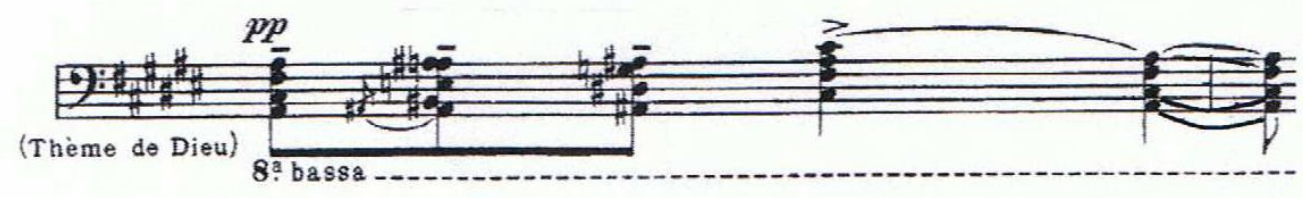

Thusly considered, the eighth-note rhythm is derived as $3+2+3$, a palindrome, although a strict nonretrogradable rhythm. ${ }^{84}$ This melodic segment appears constantly throughout the movement in the lower register, a method that Messiaen used to show that God is ever expansive and Eternal. According to Bruhn, "[a]11 rhythmic palindromes in Messiaen's music... symbolizes the absence of the temporal condition that defines all that is created." ${ }^{85}$

\footnotetext{
${ }^{83}$ Bowlby, 43.

${ }^{84}$ Bowlby, 43.

${ }^{85}$ Bruhn, Incarnation, 233.
} 
An obvious use of palindromic figures and nonretrogradable rhythms can be found in the ninth movement, Regard du Temps, where the composer obviously wanted to display his intentions of conveying time stretching into Eternity, as Messiaen uses five different rhythmic canons using nonretrogradable rhythms. A small sample of this is shown in the beginning of the movement, displayed in Ex. 4.12:

Ex. 4.12: Nonretrogradable and Palindromic Rhythms in Rhythmic Canon Movement IX, Regard du Temps

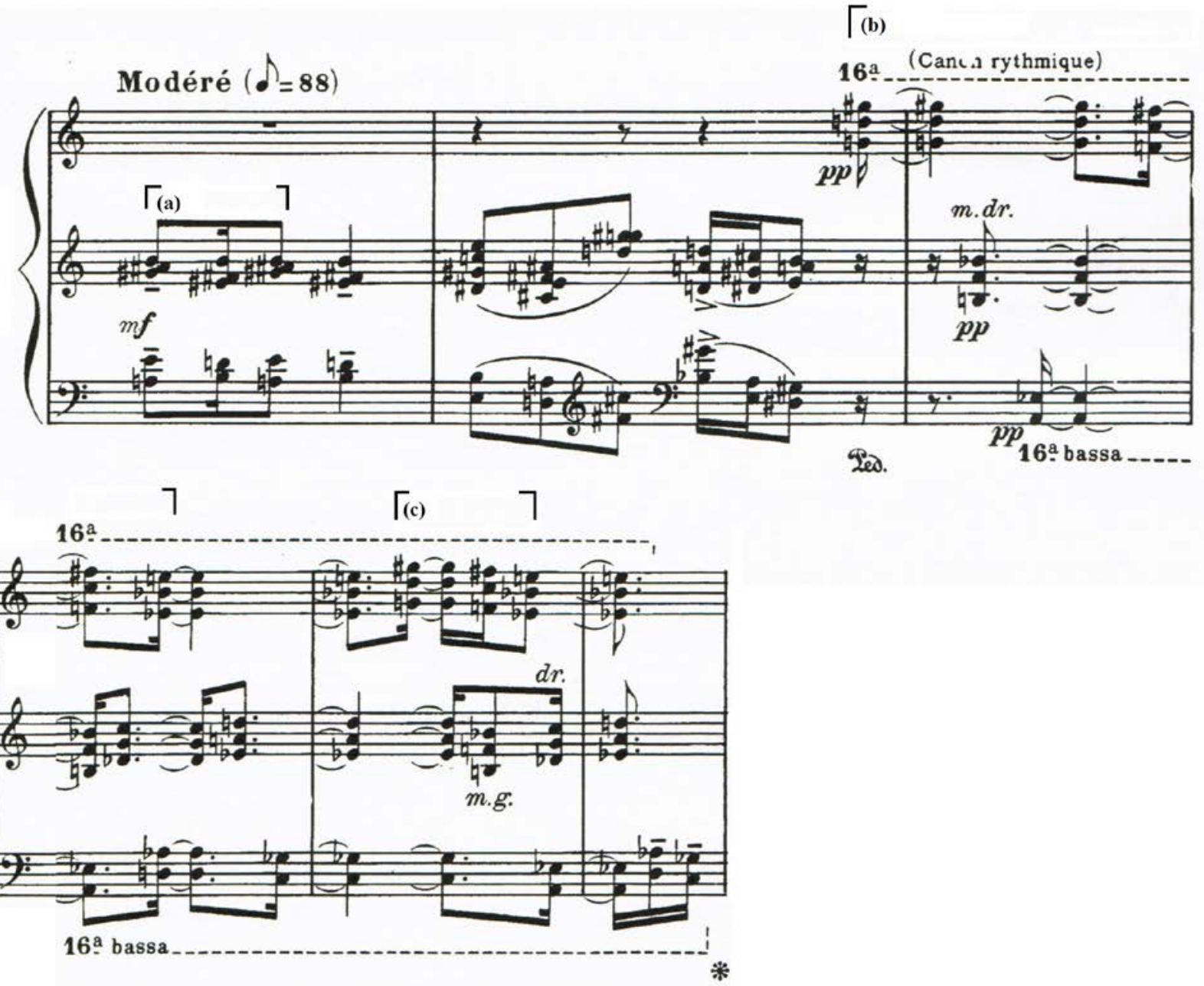

The above example shows that from the inception of the movement, the composer begins with two parts in a nonretrogradable rhythm (stated in sixteenth-note values) in (a), as it is a palindrome of $2+1+2$ rhythm. The highest part begins in section (b) with an $8+4+8$ rhythm, and 
is followed by a $2+1+2$ rhythm in (c). The play on the proportion of 2:1:2 "may serve to represent the constant aspect of Time against mankind's subjective perception of Time, [as represented by] the use of irregular values [found in] measure... two." ${ }^{186}$ Another example of nonretrogradable rhythms used to depict the essence of Eternity worth mentioning can be found in the final movement, "Regard de l'Église d'amour," as seen in Ex. 4.13:

Ex. 4.13: Nonretrogradable Rhythms in Movement XX, "Regard de l'Église d'amour”
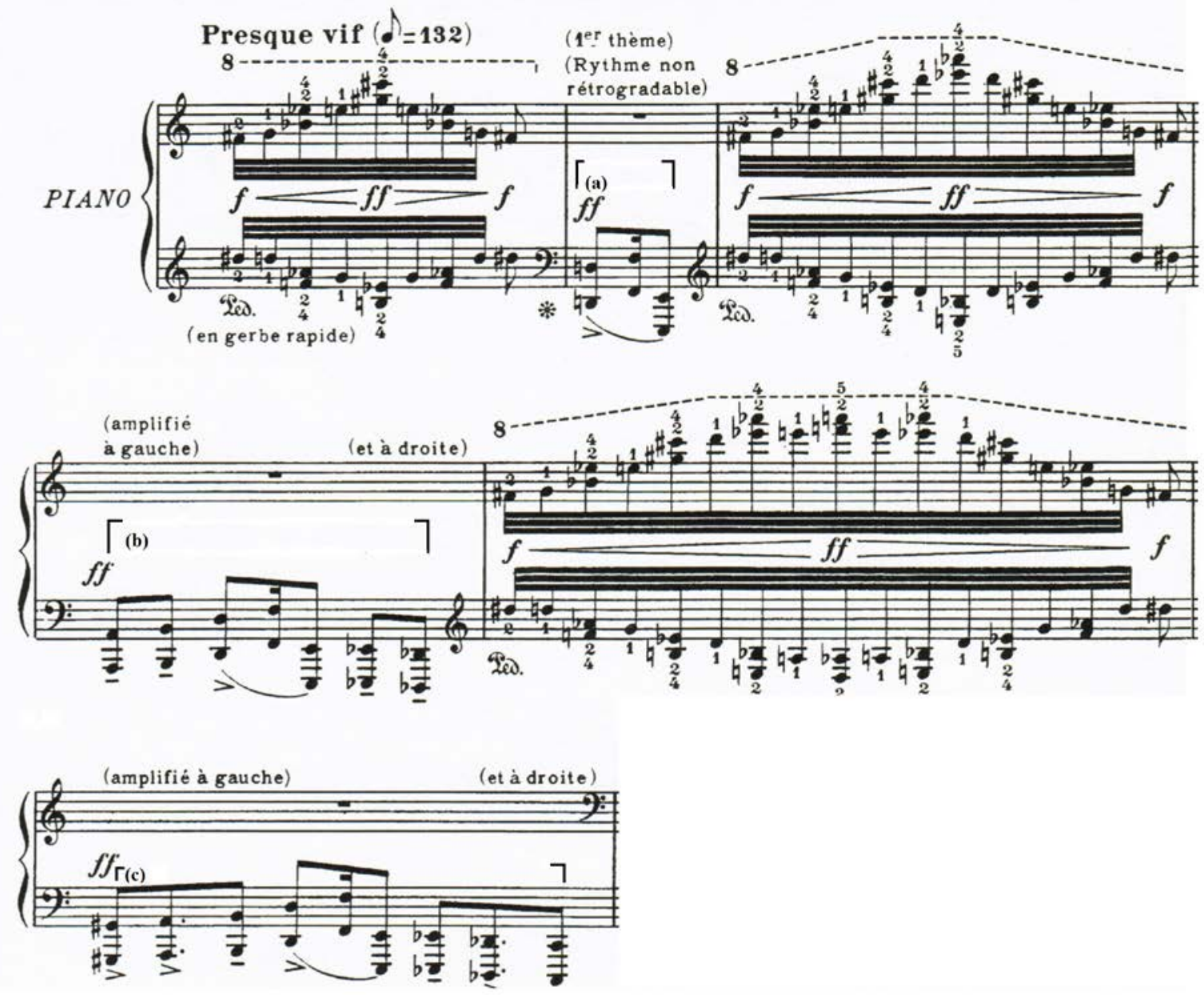

Messiaen wrote out three nonretrogradable rhythms in which the initial figure featured in (a) expands from a $2+1+2$ sixteenth-note based rhythm to $6+1+6$ in (b), then finally to $8+1+8$ in (c).

\footnotetext{
${ }^{86}$ Bowlby, 46.
} 
Not only does the expansion imply an extension of time, but according to Bruhn, also symbolizes the "community's task of spreading the message of divine love." 87

The obvious indications of Messiaen's intention to symbolize the expansion of time from the briefest of moments to eternity are abundant throughout the entire cycle, and they are sometimes used in tandem with another device, the rhythmic canon, as evidenced in the above discussion of "Regard du Temps." While what Messiaen attempted to show in this movement was the growth of time, in Regards des Anges he tried to demonstrate the angels' learning "to accept the manifestation of the eternal in time." ${ }^{18}$ As alluded to in the section relating to the Theme of Chords, the three-part rhythmic canon that appears in this movement symbolizes the struggle of coming to peace with the face that Christ will die to atone for humankind's sins. To imply the angels' eventual acceptance of the sacrifice Jesus is to make, the composer has the canon re-enter twice more, with each passage longer than the one preceding it: the first canon is but four measures long (mm. 9-13), with no line completing the initial phrase; the second entry (mm. 29-37) is eight measures long, with each component finishes the initial phrase and begins again), and the final is thirteen measures long (mm. 55-68), with all entrances completing both the initial phrase and a single repetition. ${ }^{89}$

The expansion of the rhythmic canon symbolizes the angels' growing understanding; while it is one of the most important concepts that Messiaen evoked in this cycle, so too is the concept of unity between the immortal and the mortal. This is captured in the composer's use of added values, specifically in the fifth movement, Regard du Fils sur le Fils. Referring to Ex. 4.1, the rhythm of the top stave can be illustrated as in Table 4.4a, in which they can be divided into five groups and segregated as follows, according to Bruhn: "[t]he first two of [the] five segments

\footnotetext{
${ }^{87}$ Bruhn, Incarnation, 269.

${ }^{88}$ Bruhn, Incarnation, 241.

${ }^{89}$ Bruhn, Incarnation, 240.
} 
are different variants of the shortest palindrome with three durations[;]... [t]he third and fourth components are diminutions of the first component[; while t]he fifth component... presents instead a sequence embodying linear growth." 90

Table 4.4a: Rhythmic Layout of the Top Line of "Regards du Fils sur le Fils"

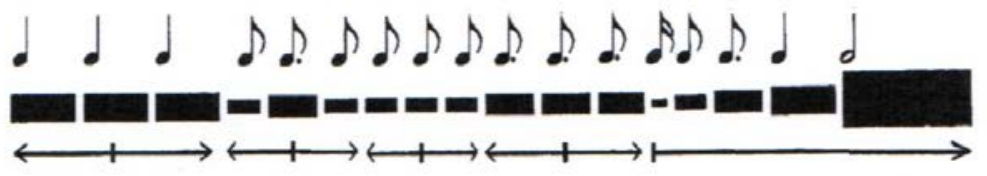

It is believed Messiaen meant to use this type of expansion as a portrayal of when "an eternal being partakes of mortal creatures' experience, ${ }^{191}$ as the palindromic elements symbolize "a point where [the human] distinction [between the reversible and irreversible] no longer applies," i.e., that which is immortal. ${ }^{92}$

While it is important to understand the rhythmic layout of this top stave as an element of the immortal, the middle strand of Ex. 4.1, which contains the added values, enlarges upon Messiaen's intention to depict the unity of both the immortal and humanity. As seen in Table $4.4 \mathrm{~b}$, the rhythmic layout of the middle line is an augmented version of the top stave as all values are increased by half of each note's value.

Table 4.4b: Rhythmic Augmentation of the Middle Stave of "Regard du Fils sur le Fils"

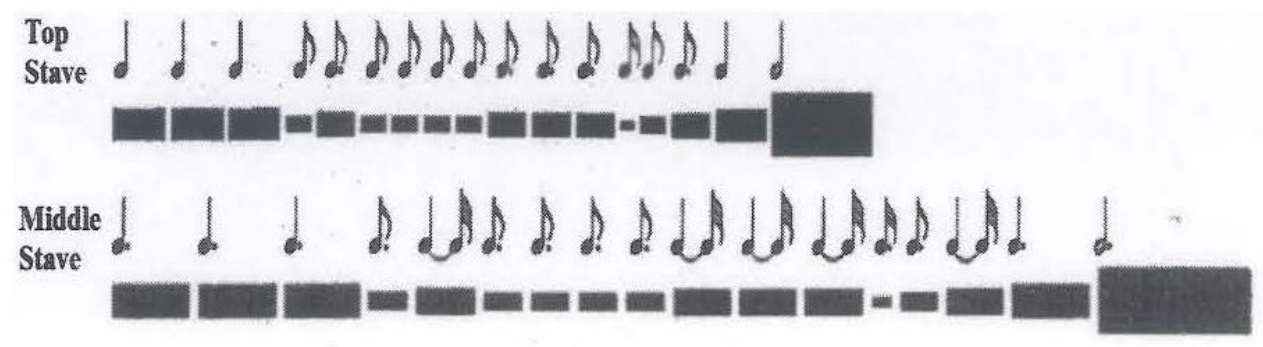

\footnotetext{
${ }^{90}$ Bruhn, Incarnation, 170, 53.

${ }^{91}$ Bruhn, Incarnation, 173.

${ }^{92}$ Bruhn, Incarnation, 53.
} 


\section{Numerology}

While thematic development, birdsong, and rhythm have been discussed in previous chapters as they figured prominently in the development of the Quatuor and the Visions, one element, numerology, clearly takes an important part in the composition of Vingt Regards. The use of numbers as symbols is extensively used throughout art and literature to convey specific meanings. Messiaen chose those numbers that traditionally had specific symbolic religious meaning.

The composer placed particular importance on the number 3, which symbolizes the Trinity. As the entire composition pertains to the different contemplations of the baby Jesus, it stands to reason that all three members of the Holy Trinity (Father, Son, and Holy Spirit) would be strongly represented. This is best exemplified in the number of main themes Messiaen chose to use. While the Theme of God needs no explanation as representing the Father, the Theme of the Star and the Cross represents Jesus the Son at two of the most crucial stages of his life: his birth and death.

While the importance of the number 3 cannot be denied in this respect, so are the implications of using number 4, an important numeral in the Book of Revelations as it depicts the Four Living Creatures, i.e., the Four Prophets. ${ }^{93}$ This can be seen in the third movement of the cycle, "L'echange,"in which the composer juxtaposed three different rhythmic segments in the first measure with four distinct groupings in the following measure (see Ex. 4.14).

\section{Ex. 4.14: Numerology Demonstrated in "L'echange"}

\footnotetext{
${ }^{93}$ Bruhn, Incarnations, 162.
} 


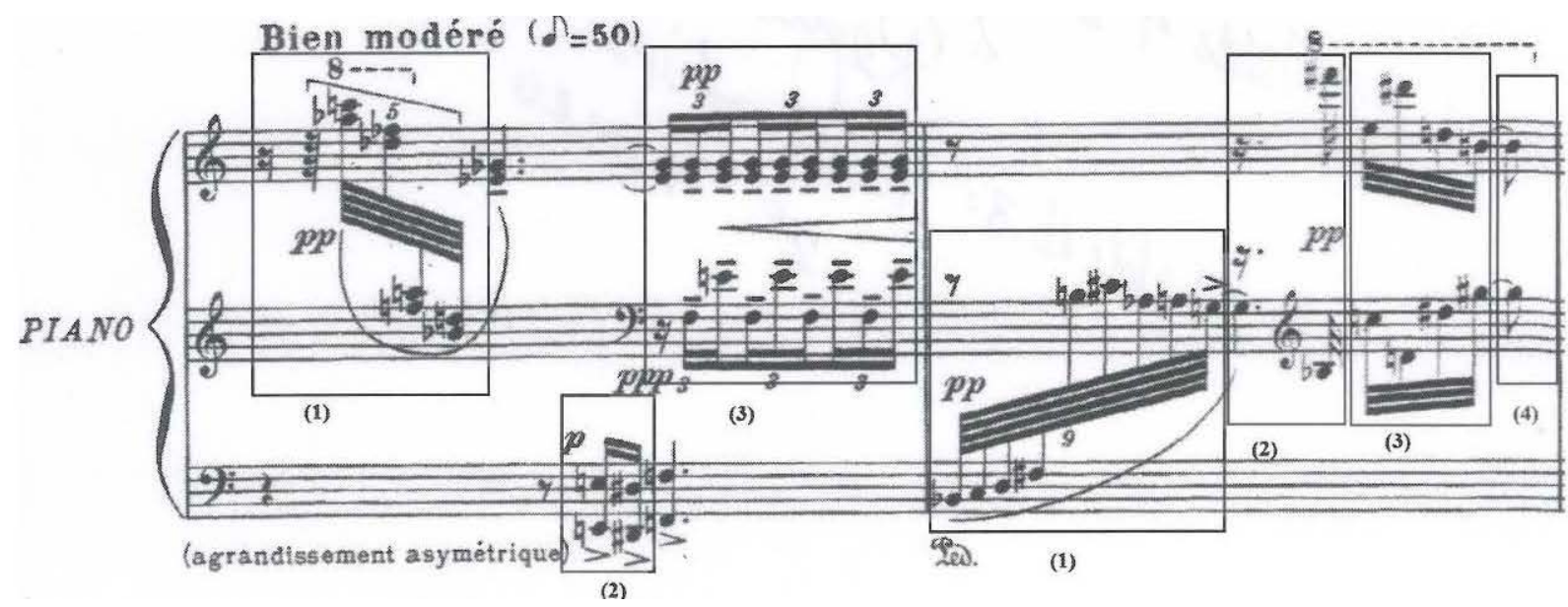

By featuring these two different values side-by-side, Messiaen not only was able to make a direct comparison between numbers three and four, but he was also able to combine them to make an allusion to 7, known in the Book of Genesis as the day God rested after creating the world. ${ }^{94}$

\section{Conclusion}

The composition of the Vingt Regards for Messiaen represents the pinnacle of the compositions he wrote for or included piano during the 1940s. Indeed, the complicated spiritual beliefs he held and the ways in which he chose to express them certainly was not limited to his writing of the twenty pieces that make up this cycle. Not only did he gain experience in trying to convey the mysteries of Christ as explained by Marmion, but he began to master many of the compositional techniques that he would use later in his lifetime, particularly thematic development, rhythmic expression, and birdsong. Although Messiaen was not to compose a major work with piano again until Réveil de oiseaux (1953), writing the Vingt Regards enabled him to understand the elements necessary to bring a large piece to fruition.

\footnotetext{
${ }^{94}$ Bruhn, Incarnations, 162.
} 
Chapter 5

Conclusions

Olivier Messiaen's need to articulate through his compositions the unique Catholic beliefs he had developed up to this point in his life ranked above all as his most important goal to achieve in this point of his career. Some of his theological convictions ran contrary to the teachings of the Church in that he tended to focus on God's loving, merciful, and graceful presence and actions rather than considering the consequences of sin and evil. While the composer did not completely ignore the wrath God had for those who refused to turn away from sin, he instead chose to focus almost solely on the part that looked at eternal salvation. By doing so, God was viewed in a more accessible manner, one in which Messiaen felt had to be shared with the rest of the world. No matter how dire or dark the settings of his music, the composer managed to convey in his message a single ray of hope. Although there are several instances where Messiaen could have dwelt on the impossibility of a situation, such as the hopelessness of the end of the world that inspired the Quatuor pour la fin du Temps, or the horror of Judgment Day depicted in Visions de l'Amen, or the despair of the Crucifixion portrayed in Vingt Regards sur l'Enfant Jésus, he instead chose to focus on the aftermath and possibilities of new beginnings that would indubitably follow these tragic circumstances, which meant the unification of humanity with God. Rather than completely ignoring the catastrophic events that served as a prelude to the hopeful, however, Messiaen briefly alluded to them in order to try to show the contrasts between the two extremes.

Aside from the obvious religious influences on him, the beliefs he embraced in his lifetime perhaps came as a product of many factors: his love for fairy tales and Shakespearean plays, his fascination for vivid colors that were enhanced by his synesthesia, and his near- 
obsession with birds and their songs seem to reveal a man who could find solace in what both his imagination and the natural world had to offer. These elements would also define the compositional techniques he would develop in his lifetime. Many of the harmonies he chose to use in his pieces centered around the brilliant colors that he saw in his mind's eye when certain combinations of pitches were played. He also chose to imitate many different birds, creatures that he considered ethereal and the real communicators of God's Word. Finally, the special phenomena and magic contained in the fairy tales and literature he treasured as a boy are paralleled in the many "charms of impossibilities" (such as the modes of limited transposition and rhythmic palindromes) that defined his musical language.

This research document was written with the intention of explaining Messiaen's unique religious beliefs and exploring the compositional techniques he used in order to convey this theology to his listeners. The unorthodox views he held seemed to have compelled him to use methods that were quite original. Indeed, during the time Messiaen began his compositional career in earnest, neoclassicism had become quite popular, a style defined by its return to moderation, leaving behind the overtly romanticized gestures that ruled the nineteenth-century musical landscape. The composer found this restrained compositional style to be inadequate to celebrate God in His greatest glory, as neoclassicism eschewed the sort of overt gestures Messiaen believed his music needed to demonstrate the love for the Almighty. He therefore began a painstakingly methodical process of utilizing musical elements in unique ways to bring alive the beliefs he held.

Developing these compositional techniques proved to be a process that would require strict methodical processes that were more formulaic than what was compared to his faith, as the composer avoided those tenets of his Catholic faith that did not coincide with this theology of 
glory. As Messiaen considered God very loving and merciful, the restrictions he applied to his theories could not be deemed as forgiving, as the rules to which he adhered stood in striking contrast to the merciful God he was venerating. For example, his attempts to portray timelessness and Eternity oftentimes required the use of nonretrogradable rhythms, which called for a rhythmic segment to be the same backwards or forwards. Another instance in which Messiaen's diligent methods came into play was in sounding out the correct arrangement of notes in order to effect the proper color combinations he wished to evoke, reflecting the influence of his synesthesia.

What also has become evident in exploring the various pieces is that the composer became more comfortable with using his musical language, so much so that he felt comfortable enough to codify it in his treatise, Technique de mon langage musical, in 1944. Interestingly, as the scope of his pieces grew immensely throughout this decade, the need to incorporate more of his compositional methods in his works also increased. The increased breadth of these compositions is a direct testament to the fact that Messiaen was becoming more at ease writing with these idioms. As time passed, he would move on to the next logical step in the evolution of his compositional style, total serialism as evidenced in his future composition, Mode de valeurs et d'intensités (1949).

Although the approach the composer used to define his theories and compositional methods was rigid in its prescribed standards (and only became more so as time passed), it is, indeed, a very personal method, one so complex that he felt it had to be explained within detailed prefaces. In each of the works examined in this document, Messiaen went to great lengths to explain the meanings behind his music, giving an account of the types of techniques used and defining what they portrayed. By doing so, the composer sought to fulfill his evangelical mission 
of bringing access to God, providing a thorough explanation of his beliefs and leading his audience through what may be construed as a difficult-to-understand theology. This importance in explaining what he wanted to display to the listener also speaks of how he wanted to control the understanding of his music.

Another part of Messiaen's compositional methods that has become apparent in the examination of these pieces is the composer's use of thematic development to convey important parts of his theology. In many ways, the individual themes used draw some parallels to Richard Wagner's own use of leitmotif, as the German composer used the device in association with certain characters or situation in his operas. The need to use such a unifying element came about as the scope of Messiaen's compositions grew and also due to the fact that his inspiration changed from a singular Scriptural passage to extensive sections of works by two of his favorite religious philosophers. Therefore, using the individual elements of his unique musical theory (as in the Quatuor) was not enough to serve as a method to remind his listeners of the components of his religious beliefs and to tie together the individual movements of these pieces as a single whole. Rather, the need arose to use a tool to accomplish both of these goals. By developing recurring themes that could be tied to different religious symbols, (such as God or the Star and the Cross in Vingt Regards), Messiaen was able to weave together different parts of his musical language, such as incorporating birdsong and rhythm to relay the thoughts of Eternity and God's heavenly creatures together in the fifth movement of the Visions de l'Amen, "Amen des anges, des saints, du chant des oiseaux.”

The development of these compositional devices in order to demonstrate the unique theology Messiaen held indeed makes him one of the most distinctive composers of the twentieth century. However, the reception of his music met its share of resistance from the general public 
and critics alike. As journalist Bernard Gavoty in the periodical Le Figaro wrote in 1945, he and other audience members felt Vingt Regards had "not a hint of tenderness in this suite... to evoke the eternity of the stars, a great gaggle of chords, immobile to the point of nausea, then rearing up in sudden convulsions. Is this heaven? No, it's purgatory."1 The critic's opinion of Messiaen's music would persist for two years afterward, a period in which Messiaen endured incredible selfdoubt. Yet the message he tried to bring to the public was, he believed, divinely given, and that his faith in God would be enough to provide encouragement for him to continue writing in this manner. He continued to write religious-inspired pieces throughout his lifetime, and the breadth and content of the three pieces examined in this document proved an excellent training ground for the compositions to follow.

\footnotetext{
${ }^{1}$ Bernard Gavoty, trans. in Peter Hill and Nigel Simeone, Messiaen (New Haven, CT: Yale University Press, 2005): 144.
} 


\section{COMPREHENSIVE BIBLIOGRAPHY}

Works consulted for this research document are denoted by an asterisk (*)

BOOKS

Benitez, Vincent Perez. Olivier Messiaen: A Research and Information Guide. Routledge Music Bibliographies. Routledge, 2007.

* Bruhn, Siglind, ed. Messiaen’s Language of Mystical Love. New York: General Music Publishing, 1998.

$*$ Images and Ideas in Modern French Piano Music: The Extra-Musical Subtext in Piano Works by Ravel, Debussy, and Messiaen. Aesthetics in Music, no. 6. Stuyvesant, NY: Pendragon Press, 1997.

$*$ . Messiaen's Contemplations of Covenant and Incarnation: Musical Symbols of Faith in the Two Great Piano Cycles of the 1940s. Dimension and Diversity, no. 7. Hillsdale, NY: Pendragon Press, 2007.

* Dingle, Christopher Philip. The Life of Messiaen. Cambridge, UK: Cambridge University Press, 2007.

* Fulcher, Jane F. The Composer as Intellectual: Music and Ideology in France, 1914-1940. New York: Oxford University Press, 2005.

* Hill, Peter, ed. The Messiaen Companion. Portland, OR: Amadeus Press, 1995.

* Hill, Peter, and Nigel Simeone. Messiaen. Mainz, Germany: Schott, 2007.

* Johnson, Robert Sherlaw. Messiaen. London: Dent, 1975.

* Messiaen, Olivier. The Technique of My Musical Language. Translated by John Satterfield. Paris: Alphonse Leduc, 1966.

Nichols, Roger. Messiaen. Oxford Studies of Composers, no. 13. New York: Oxford University Press, 1986.

* Pople, Anthony. Messiaen: Quatuor pour la fin du temps. Cambridge Music Handbooks. Cambridge, UK: Cambridge University Press, 1998.

* Rischin, Rebecca. For the End of Time: The Story of the Messiaen Quartet. Ithaca, NY: Cornell University Press, 2003.

* Ross, Alex. The Rest is Noise. New York: Picador, 2008.

* Rossler, Almut, comp. Contributions to the Spiritual World of Olivier Messiaen: with Original 
Texts by the Composer. Translated by Barbara Dagg and Nancy Poland. Duisburg, Germany: Gilles and Francke, 1986.

* Samuel, Claude. Olivier Messiaen: Music and Color - Conversations with Claude Samuel. Translated by Thomas E. Glasgow. Portland, OR: Amadeus, 1994.

Schloesser, Stephen. Jazz Age Catholicism: Mystic Modernism in Postwar Paris, 1919-1933. Toronto: University of Toronto, 2005.

* Shenton, Andrew. Olivier Messiaen's System of Signs: Notes Towards Understanding His Music. Burlington, VT: Ashgate Publishing, 2007.

* van Maas, Sander. The Reinvention of Religious Music: Olivier Messiaen's Breakthrough Toward the Beyond. New York: Fordham University Press, 2009. 


\section{DISSERTATIONS AND THESES}

Anderson, Shane Dewayne. "Vingt regards sur l'Enfant-Jesus by Olivier Messiaen: An Analysis of Its Content, Spiritual Significance and Performance Practice." DMA diss., University of Texas at Austin, 1999.

* Bowlby, Christopher S. "Vingt regards sur l'enfant-Jesus: Messiaen's Means of Conveying Extra-Musical Subtext." DMA diss., University of Washington, 2005.

Dukes, Leslie Dianne. “ An Exploration of Olivier Messiaen's Piano Style and Application of Color in 'Le Baiser de l'Enfant-Jesus' and 'Le Courlis Cendre'.” DMA diss., University of Arizona, 1998.

Ennis, Paula. "A Study of Coherence and Unity in Messiaen's Cycle Vingt Regards sur l'EnfantJésus. DM diss., Indiana University, 1979.

Epstein, Heidi. "The Nature of the Relationship between Music and Theology according to Oskar Sohngen and Olivier Messiaen.” MA thesis, McGill University, 1990.

Gunden, Heidi Cecilia von. "Timbre as Symbol in Selected Works of Olivier Messiaen." PhD diss., University of California at San Diego, 1977.

Hardink, Jason M. “Messiaen and Plainchant.” DMA diss., Rice University, 2007.

Haslett, Dora Poulson ."The Harmonic, Rhythmic and Melodic Theories of Olivier Messiaen Utilized in the Vingt Regards sur l'enfant Jésus," M.M. Thesis, University of Portland, 1965.

Hickman, Melinda. "Meaning in Piano Music with a Religious Theme: A Philosophical and Historical Approach (Johann Kuhnau, Joseph Haydn, Franz Liszt, Olivier Messiaen)." DMA diss., University of Cincinnati, 2001.

Hill, Matthew Richard. "Messiaen's "Regard du silence" as an expression of Catholic faith." DMA, University of Wisconsin - Madison, 1995.

Lee, Hyeweon. “Olivier Messiaen't Vingt Regards sur l'Enfant-Jesus: A Study of Sonority, Color, and Symbol." DMA diss., University of Cincinatti, 1992.

Lin, Yi-Ting. “A Comparison of Scriabin's Last Five Piano Sonatas and Messiaen's Vingt Regards sur L'Enfant Jésus: Analyses of Sonata No. 7, and Contemplations I, IV, and XX.” DMA diss., Southwestern Baptist Theological Seminary, 1999.

Luchese, Diane. “Olivier Messiaen's Slow Music: Glimpses of Eternity in Time.” PhD diss., Northwestern University, 1998. 
McGinnis, Margaret Elizabeth. "Playing the Fields: Messiaen, Music, and the Extramusical." PhD diss., University of North Carolina at Chapel Hill, 2003.

McKinnon, Heather Price. "Symbolism and theology as compositional genesis in Vingt regards sur l'enfant Jésus by Olivier Messiaen." DMA thesis, University of Iowa, 1991.

* Rogosin, David. "Aspects of Structure in Olivier Messiaen's Vingt Regards sur l'Enfant-Jesus." DMA diss., University of British Columbia.

Seifert, Charles Ernest. "Messiaen's Vingt Regards sur l”Enfant-Jesus: A Historical and Pedagogical Study." EdD diss., University of Illinois at Urbana-Champaign, 1989.

Sholl, Robert P. "Olivier Messiaen and the Culture of Modernity.” PhD diss., King's College, University of London, 2003.

Whitmore, Brooks Blaine. "Rhythmic techniques in Olivier Messiaen's Vingt Regards sur l'Enfant-Jesus." DMA diss., University of Texas at Austin, 1996.

Zheng, Zhong. "A study of Messiaen's solo piano works." PhD diss., The Chinese University of Hong Kong, People's Republic of China, 2004. 


\section{ARTICLES IN JOURNALS, COMPILATIONS AND ONLINE DATABASES}

Asplund, Christopher. "A Body without Organs: Three Approaches - Cage, Bach, and Messiaen.” Perspectives of New Music 35, no. 2 (Summer 1997): 171-187.

Bernard, Jonathan W. "Colour." In The Messiaen Companion, ed. Peter Hill. Portland, OR: Amadeus Press, 1995: 203-219.

Bruhn, Siglind. "Religious Symbolism in the Music of Olivier Messiaen." The American Journal of Semiotics 13 (Fall 1998): 277-309.

. "The Spiritual Layout of Messiaen's Contemplations of the Manger." In Messiaen's Language of Mystical Love, ed. Siglind Bruhn. New York: General Music Publishing, 1998.

. "Traces of a Thomistic De Musica in the Compositions of Olivier Messiaen." Logos: A Journal of Catholic Thought and Culture 11, no. 4 (Fall 2008): 16-56.

Dalferth, Ingolf U. "Representing God's Presence.” International Journal of Systematic Theology 3, no. 3 (November 2001): 237-256.

* Darbyshire, Ian. "Messiaen and the Representation of the Theological Illusion of Time." In Messiaen’s Language of Mystical Love, ed. Siglind Bruhn. New York: General Music Publishing, 1998.

* Fabbi, Roberto. "Theological Implications of Restrictions in Messiaen's Compositional Processes.” In Messiaen’s Language of Mystical Love, ed. Siglind Bruhn. New York: General Music Publishing, 1998.

* Foreman, Edward. “ 'L'Harmonie de l'Univers': Maurice Toesca and the Genesis of Vingt Regards sur l'enfant Jésus." In Olivier Messiaen: Music, Art, and Literature, eds. Christopher Dingle and Nigel Simeone. Burlington, VT: Ashgate, 2007: 13-22.

* Gavoty, Bernard. “Who are you, Olivier Messiaen?” Tempo 58 (1961): 33-36.

* Griffiths, Paul. "Messiaen, Olivier (Eugéne Prosper Charles).” Grove Music Online, ed. L. Macy. [28 November 2007].

Johnson, Robert Sherlaw. "Mythology and Symbolism in Messiaen’s Music.” Modern Churchman 17, no. 1 (October 1973): 60-63.

* _. "Rhythmic Technique and Symbolism in the Music of Olivier Messiaen." In Messiaen's Language of Mystical Love, ed. Siglind Bruhn. New York: General Music Publishing, 1998 
Linton, Michael R. "Music for the End of Time." First Things: A Monthly Journal of Religion and Public Life 87 (November 1998): 13-15.

* Matheson, Iain. "The End of Time: a Biblical Theme in Messiaen's Quatuor." In The Messiaen Companion. Portland, OR: Amadeus Press, 1995: 234-48.

* "Mysticism," Merriam-Webster Dictionary Online (Accessed 12 November 2010), http://www.merriam-webster.com/dictionary/mysticism.

Otten, Susan Tracey. "Ernest Hello", ed. Kevin Knight (Accessed 12 November 2010), http://www.newadvent.org/cathen/16044b.htm.

* Pople, Anthony. "Messiaen's Musical Language: an Introduction," In The Messiaen Companion, ed. Peter Hill (Portland, OR: Amadeus Press, 1995): 15-50.

Simeone, Nigel. "Messiaen and the Concerts de la Pléiade: "A Kind of Clandestine Revenge Against the Occupation," Music and Letters, 81, no. 4 (November 2000): 551-584 


\section{MUSICAL SCORES AND RECORDINGS}

* Messiaen, Olivier. Quatuor pour la fin du Temps. Paris: Durand Editions Musicales, 1941.

* Messiaen, Olivier. Vingt Regards sur l'enfant Jésus. Paris: Durand Editions Musicales, 1947.

* Messiaen, Olivier. Visions de l'Amen. Paris: Durand Editions Musicales, 1943.

* Works for Piano Duo - Messiaen: Visions de l'Amen; Beethoven Grosse Fuge, performed by Duo D’Accord. Oehms Classics B0021JLQVK, 2008. CD. 